NBER WORKING PAPER SERIES

\title{
CLOSING THE GAP: \\ THE EFFECT OF A TARGETED, TUITION-FREE PROMISE ON COLLEGE CHOICES OF HIGH-ACHIEVING, LOW-INCOME STUDENTS
}

\author{
Susan Dynarski \\ C.J. Libassi \\ Katherine Michelmore \\ Stephanie Owen \\ Working Paper 25349 \\ http://www.nber.org/papers/w25349 \\ NATIONAL BUREAU OF ECONOMIC RESEARCH \\ 1050 Massachusetts Avenue \\ Cambridge, MA 02138 \\ December 2018
}

This project would not have been possible without our collaborators at the University of Michigan-particularly Kedra Ishop, Steve Lonn, and Betsy Brown. We are grateful to the Michigan Department of Education (MDE) and Michigan's Center for Educational Performance and Information (CEPI) for providing data. Seminar participants at Boston University, Clemson, Cornell, Harvard, Northwestern, University of Illinois, University of Virginia, Princeton, Chicago, Stanford, the National Bureau for Economic Research, and Syracuse provided helpful comments, while Michael Lovenheim and Sarah Turner read initial drafts. The Institute of Education Sciences of the U.S. Department of Education (through Grants R305E100008 and R305B110001), Arnold Ventures, the Smith Richardson Foundation, and the University of Michigan Provost's Office funded this research. This study is registered at the randomized trial registry of the American Economics Association under RCT ID AEARCTR-0001831, with DOI 10.1257/rct.1831. A pre-analysis plan was filed in April 2017. Elizabeth Burland, Meghan Oster, and Shwetha Raghuraman provided outstanding research assistance. Results, information and opinions solely represent the analysis, information and opinions of the authors and are not endorsed by, or reflect the views or positions of, grantors, the National Bureau of Economic Research, MDE and CEPI or any employee thereof.

NBER working papers are circulated for discussion and comment purposes. They have not been peerreviewed or been subject to the review by the NBER Board of Directors that accompanies official NBER publications.

(C) 2018 by Susan Dynarski, C.J. Libassi, Katherine Michelmore, and Stephanie Owen. All rights reserved. Short sections of text, not to exceed two paragraphs, may be quoted without explicit permission provided that full credit, including (C) notice, is given to the source. 
Closing the Gap: The Effect of a Targeted, Tuition-Free Promise on College Choices of High-Achieving, Low-Income Students

Susan Dynarski, C.J. Libassi, Katherine Michelmore, and Stephanie Owen

NBER Working Paper No. 25349

December 2018, Revised June 2020

JEL No. I0,I21,I22,I23,I24,I28

\section{ABSTRACT}

High-achieving, low-income students attend selective colleges at far lower rates than upperincome students with similar achievement. Behavioral biases, intensified by complexity and uncertainty in the admissions and aid process, may explain this gap. In a large-scale experiment we test an early commitment of free tuition at a flagship university. The intervention did not increase aid: rather, students were guaranteed before application the same grant aid that they would qualify for in expectation after admission. The offer substantially increased application (68 percent vs 26 percent) and enrollment rates ( 27 percent vs 12 percent). The results suggest that uncertainty, present bias, and loss aversion loom large in students' college decisions.

Susan Dynarski

University of Michigan

Weill Hall

735 South State Street

Ann Arbor, MI 48109-3091

and NBER

dynarski@umich.edu

C.J. Libassi

College Board

1919 M Street NW

Suite 300

Washington, DC 20036

clibassi@collegeboard.org
Katherine Michelmore

Syracuse University

Center for Policy Research

426 Eggers Hall

Syracuse, NY 13244

kmmichel@syr.edu

Stephanie Owen

University of Michigan

238 Lorch Hall

611 Tappan Ave.

Ann Arbor, MI 48109-1220

srowen@umich.edu

A randomized controlled trials registry entry is available at https://www.socialscienceregistry.org/trials/1831 


\section{INTRODUCTION}

Gaps in educational attainment between low- and high-income students are large and have grown in recent decades. Among children born in the 1980s, those from the bottom quartile of family incomes are 50 percentage points less likely to attend college than those from the top quartile. And while 54 percent of children born into the top income quartile earned a bachelor's degree, only nine percent of those in the lowest quartile did so (Bailey and Dynarski 2011).

These differences stem in part from disparities in academic preparation. But even among well-prepared students, there are substantial gaps in college enrollment and the quality of college attended (Hoxby and Avery 2012). Combined with evidence that attending a college of higher quality increases both educational attainment and earnings (Hoekstra 2009; Zimmerman 2014; Dillon and Smith 2018), the under-representation of low-income students at selective colleges likely exacerbates both educational and income inequality. ${ }^{1}$

Among high-achieving students, differences in application behavior drive income differences in college quality. Hoxby and Avery (2012) find that the majority of low-income, high-achieving students apply to zero selective schools, even though doing so would likely lower their costs (Cohodes and Goodman 2014), increase their chances of completing a college degree, and increase their future wages (Hoekstra 2009, Zimmerman 2014; Andrews, Imberman and Lovenheim 2016).

Standard models of human capital investment fall short in explaining these behaviors. Though a lack of information about the (net) cost of college or suitability for an elite school could in theory lead low-income students to underinvest in education, previous interventions targeting these information frictions have shown only modest success (Bettinger et al. 2012; Hoxby and Turner 2013; Bergman, Denning and Manoli 2019; Gurantz et al. 2019; Hyman 2019, although see Jensen 2010 for an exception). Insights from behavioral economics suggest that students' choices deviate from the classical model in predictable ways. Many observed behavioral patterns, such as present bias, overreliance on routine or defaults, and debt aversion, are particularly pronounced for those facing economic scarcity (which by definition low-income students are) and complex decisions (as in the higher education and financial aid systems) (Mullainathan and Shafir 2013). Within such an environment, small changes can lead to a large difference in behavior.

We use a randomized, controlled trial to test whether targeted, personalized communications, which reframe but do not increase financial aid, can alter the college decisions of low-income students. The intervention, the "HAIL (High Achieving Involved Leader) Scholarship," ${ }^{2}$ was designed in the spirit of previous interventions that make small changes to the framework of decision-making with the hope of inducing large changes in behavior.

In a personalized mailing, two cohorts of two thousand low-income, high-achieving students were encouraged to apply to the University of Michigan in Ann Arbor (the state's most selective school) and

\footnotetext{
${ }^{1}$ We interchangeably use the terms "high quality", "selective", and "elite" throughout to refer to selective institutions. These schools tend to spend more per student, as well as provide high-achieving classmates who are inputs into the education production function (Black and Smith 2006).

${ }^{2}$ The acronym "HAIL" is a reference to the University of Michigan's fight song. "HAIL Michigan" is plastered on t-shirts, bumper stickers, water bottles, tube tops, underwear, beer coolers, dog coats, and billboards across the state and beyond. Go Blue!
} 
promised free tuition and fees if admitted. ${ }^{3}$ Parents and principals of the eligible students were also notified about this offer. Students enrolled in Michigan public schools who qualified for subsidized school meals and met certain academic criteria (described in Section III) were eligible for the scholarship.

Crucially, this intervention did not change costs for these students: rather, it offered an early guarantee of grants for which, in expectation, they were already eligible. This offer was made in the fall of a student's senior year of high school, before college application deadlines; traditionally, aid offers are made after a student is accepted. The offer was unconditional; traditionally, in order to qualify for aid, students must complete a set of forms that are more complicated than the typical tax return (Dynarski and Scott-Clayton 2006). Finally, the scholarship was guaranteed for four years; traditionally, schools require an annual application for aid.

We find very large effects of the intervention offer on application and enrollment rates at the University of Michigan and, more generally, on college choice. The likelihood of applying to the University of Michigan more than doubled, from 26 percent among controls to 68 percent among students offered treatment. The share enrolling at a highly selective college more than doubled, from 13 percent to 28 percent, with this effect operating completely through enrollment at the University of Michigan.

One-quarter of the enrollment effect (four percentage points) is driven by students who would not have attended any college in the absence of the treatment. The balance would have attended a community college or a less selective four-year college. The offer of the scholarship diverted no students from colleges as or more selective than the University of Michigan - that is, there was no "poaching" from other selective schools. Nor did the offer increase attendance at other selective schools, which plausibly could have been induced by mailings that told students that they were strong candidates for admission to the selective University of Michigan.

The magnitudes of these effects are much larger than those in previous interventions with similar goals (Hoxby and Turner 2013; Bettinger et al. 2012; Goldrick-Rab et al. 2016; Bergman, Denning and Manoli 2017; Oreopoulos and Ford 2019; Gurantz et al. 2019; Hyman 2019). Several dimensions of the HAIL intervention set it apart, and plausibly explain the size of its effect.

The HAIL Scholarship provides an early, unconditional guarantee of free tuition. The early nature of the offer locks in a price guarantee at the time of the application decision. Previous research suggests that information is most effective when delivered at the time of decision making (Fernandes, Lynch Jr and Netemeyer 2014; Fischer and Wagner 2018; Patterson, Pope and Feudo 2019).

The offer is unconditional: though students must still apply and be admitted, they do not have to fill out any paperwork or go through any verification to qualify for the scholarship. ${ }^{4}$ Although the costs of learning about and applying for financial aid are small compared to its value (and the benefits of college), previous research suggests that even minor and short-term costs can have an outsize influence on the decisions of

\footnotetext{
${ }^{3}$ Barron's ranks schools from "least competitive" to "most competitive" based on a combination of average GPA, SAT scores, and acceptance rates. The University of Michigan is in the "highly competitive" or second highest category.

${ }^{4}$ While submitting aid forms was not required to receive the HAIL Scholarship, applicants were encouraged to do so. University of Michigan staff prodded admitted students to complete forms, and 95 percent of the admitted HAIL Scholars did so, thereby substantially increasing their aid.
} 
myopic students (Oreopoulos and Ford 2019; Hoxby and Turner 2013; Goodman 2016; Pallais 2015; Bulman 2015). The HAIL offer effectively changes the default option for students, in that no action is required to accept it. Previous research indicates that people use shortcuts in complex decision environments, and that changing defaults can therefore dramatically influence behavior (Marx and Turner 2019; Pallais 2015; Johnson and Goldstein 2009; Beshears et al. 2013).

Finally, the four-year guarantee reduces the uncertainty of future college costs, by converting the possibility of future aid into a present certainty.

Our results show that a low-cost intervention that removes behavioral and administrative obstacles can profoundly alter student choices. We add to a growing body of research that shows that seemingly minor differences in policy design can have profound effects on real economic outcomes. In ongoing work, we track the effects of the intervention on college major, persistence, and graduation. In the long term, we will examine the effect of the induced changes in educational attainment on earnings and other measures of adult well-being.

\section{BACKGROUND}

\section{A Income Gaps in College Quality and Why They Matter}

A long literature informs the design of the HAIL scholarship and our understanding of income-based gaps in college going.

Just 12 percent of college students come from the bottom fifth of the family-income distribution, while 28 percent are from the top fifth. This imbalance is even larger at the most selective colleges (Chetty et al. $2017)^{5}$, which have more students from the top one percent of the income distribution than from the entire bottom half.

Undermatching accounts for some of this gap in college selectivity. Students are said to undermatch when they are much more academically qualified than typical peers at their chosen school. Only 38 percent of Chicago Public Schools students who qualify for very selective colleges attend one (Roderick, Coca and Nagaoka 2011). Similarly, Bowen, Chingos and McPherson (2009) found that, among students in North Carolina in 1999, 40 percent did not attend the highest-tier institution for which they were likely eligible given their academic performance. This concurs with a study of two nationally-representative cohorts of high school graduates from 1992 and 2004 (Smith, Pender and Howell 2013).

Hoxby and Avery (2012) and Dillon and Smith (2017) find that the main driver of mismatch is student application choices rather than schools' admissions decisions. That is, low-income students wind up at schools of lower selectivity not because they were rejected from the better schools but because they never applied. Dillon and Smith (2017) find that, among the students who undermatch, 72 percent applied to no closely matched college; just six percent applied to such colleges but were rejected. Hoxby and Avery (2012) show that many qualified students apply to no selective colleges at all.

\footnotetext{
${ }^{5}$ The authors refer to these institutions as the "Ivy Plus" and include the eight Ivy League schools plus MIT, Stanford, Duke, and the University of Chicago.
} 
In Michigan, as in the rest of the country, there are large differences in college choices between low- and higher-income students. Among students whose high academic achievement makes them plausible candidates for a selective school, low-income students are four percentage points less likely to attend any college than their higher-income peers (see Figure I). Gaps in college selectivity are even wider than gaps in college attendance: low-income students are eight percentage points less likely than more advantaged peers to attend a highly selective school.

\section{Figure I}

Selectivity of Colleges Attended by High-Achieving Michigan Students, by Income

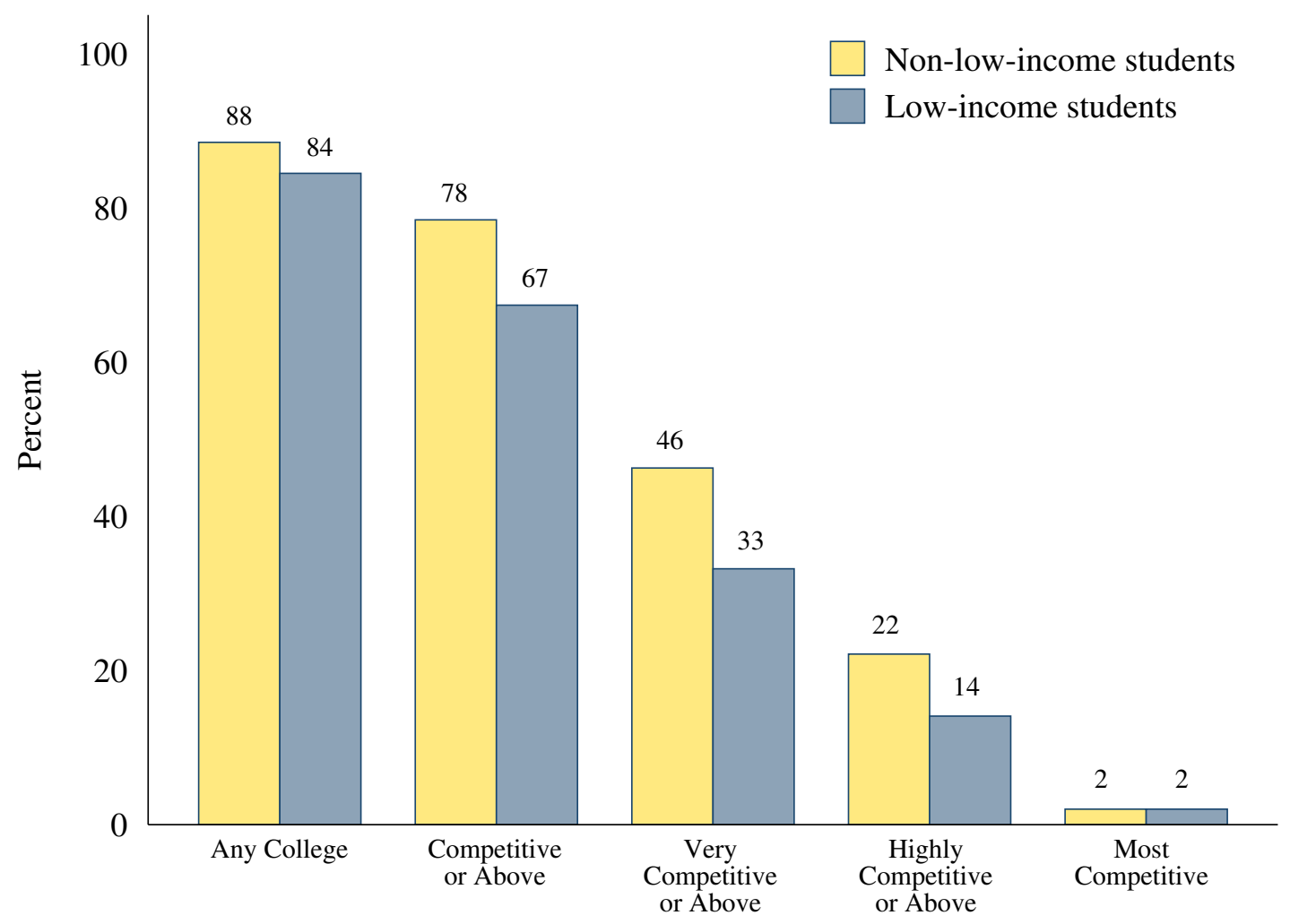

Source: Michigan administrative data and National Student Clearinghouse data.

Notes: Sample is 11th grade students in Michigan public schools in 2013 who meet HAIL GPA and ACT criteria. College enrollment measured at first institution attended in fall 2014. Low-income means eligible for free or reduced-price lunch in 11 th grade. Selectivity categories from Barron's selectivity index.

More selective schools typically offer more aid to low-income students, making them cheaper than less selective schools (see Table I). The net cost of attendance at the University of Michigan for in-state students with family income below $\$ 30,000$ is $\$ 3,249 .^{6}$ This makes the University of Michigan the cheapest four-year option for low-income students in the state; their net cost of attendance is \$7,058 at Michigan State University, and \$12,316 at Eastern Michigan University. For students with slightly higher family income (between $\$ 30,000$ and $\$ 48,000$ ), the net cost of attendance at the University of Michigan is $\$ 5,575$. $^{7}$ For these

\footnotetext{
${ }^{6}$ From College Scorecard data.

${ }^{7}$ This is roughly 130-185 percent of the federal poverty threshold for a family of four, and corresponds to the upper income thresholds for free or subsidized meals in school.
} 
students, only a community college is a cheaper option than the University of Michigan (nearby Washtenaw Community college costs $\$ 4,455) .^{8}$

Higher college quality is associated with higher graduation rates and salaries. Research indicates that at least part of this relationship is causal (Hoekstra 2009; Zimmerman 2014; Dillon and Smith 2018). The University of Michigan has a 91 percent graduation rate (within six years) and an average alumni salary of over $\$ 63,000$ (within ten years of attendance). The comparable statistics at nearby Eastern Michigan University are 41 percent and $\$ 39,300$. Shifting low-income students to the University of Michigan is therefore likely to increase both their educational attainment and adulthood income.

Table I

Characteristics of Selected Universities in Michigan

\begin{tabular}{|c|c|c|c|c|}
\hline & $\begin{array}{l}\text { University } \\
\text { of } \\
\text { Michigan }\end{array}$ & $\begin{array}{c}\text { Michigan } \\
\text { State } \\
\text { University }\end{array}$ & $\begin{array}{l}\text { Eastern } \\
\text { Michigan } \\
\text { University }\end{array}$ & $\begin{array}{c}\text { Washtenaw } \\
\text { Community } \\
\text { College }\end{array}$ \\
\hline Barron's selectivity category & $\begin{array}{c}\text { Highly } \\
\text { competitive }\end{array}$ & $\begin{array}{c}\text { Very } \\
\text { competitive }\end{array}$ & Competitive & Not rated \\
\hline \multicolumn{5}{|l|}{ Average annual net cost for in-state students } \\
\hline All students & $\$ 14,860$ & $\$ 18,576$ & $\$ 14,406$ & $\$ 5,286$ \\
\hline Students with family income $\$ 0-30 \mathrm{~K}$ & $\$ 3,249$ & $\$ 7,058$ & $\$ 12,316$ & $\$ 3,912$ \\
\hline Students with family income $\$ 30-48 \mathrm{~K}$ & $\$ 5,575$ & $\$ 13,116$ & $\$ 12,951$ & $\$ 4,455$ \\
\hline Graduation rate & 0.91 & 0.79 & 0.41 & 0.15 \\
\hline Median salary after attending & $\$ 63,400$ & $\$ 53,600$ & $\$ 39,300$ & $\$ 29,200$ \\
\hline
\end{tabular}

Source: College Scorecard, https://collegescorecard.ed.gov, accessed May 30, 2019.

Notes: University of Michigan refers to the Ann Arbor campus. Average annual net cost is "derived from the full cost of attendance (including tuition and fees, books and supplies, and living expenses) minus federal, state, and institutional grant/scholarship aid, for full-time, first-time undergraduate Title IV-receiving students." Average net cost is reported for this group as well as for subsets of students in the two lowest income brackets reported by College Scorecard $(\$ 0-\$ 30,000$ and $\$ 30,001-\$ 48,000)$. For reference, the cutoff for free lunch eligibility for a family of four is $\$ 33,104$ (130 percent of the federal poverty line), and for reduced-price eligibility it is $\$ 47,638$ (185 percent of the federal poverty line) as of 2019. The graduation rate for the four-year schools is the proportion of first-time, full-time students who complete a bachelor's degree within six years; for Washetenaw Community College it is the proportion of first-time, full-time students who complete a two-year degree within three years. Median salary represents "the median earnings of former students who received federal financial aid, at 10 years after entering the school." All quotes are from College Scorecard.

\section{B Lessons from previous literature and interventions}

The facts laid out above present a puzzle: given their substantial benefits and relatively low costs, why aren't selective colleges the destination for more low-income, high-achieving students? It is difficult to square this behavior with the human capital model, in which people weigh the expected costs and benefits of schooling, choosing the option that maximizes the return over a lifetime. We might conclude (and evidence shows) that students are uninformed, and that providing information about the costs and benefits of college would make a difference in their decisions (Avery and Kane 2004; Dynarski and Scott-Clayton 2006; Oreopoulos

\footnotetext{
${ }^{8}$ Table I includes four illustrative example schools, but the point holds more broadly. For students in the two lowest income categories, the University of Michigan in Ann Arbor is the most affordable bachelor's-degree-granting school in the state.
} 
and Dunn 2013). ${ }^{9}$ Unfortunately, multiple studies have found that information alone does not change student behavior (Bettinger et al. 2012; Hoxby and Turner 2013; Bergman, Denning and Manoli 2019; Gurantz et al. 2019; Hyman 2019, although see Jensen 2010 for an exception).

Behavioral economics provides plausible explanations for why low-income, high-achieving students attend selective colleges at far lower rates than their higher-income peers. ${ }^{10}$ Research in the lab and in the field has identified a number of behavioral phenomena that can explain consistently observed patterns in educational decision-making. First, people often exhibit time-inconsistent preferences and appear present-biased (Frederick, Loewenstein and O'Donoghue 2002; Stanovich, West and Toplak 2012). They act in ways inconsistent with their stated goals for the future, and overemphasize short-term costs and benefits (Ainslie 1975; Laibson 1997). Due to their still-developing brain systems, which affect cognitive functioning and critical thinking, adolescents are particularly susceptible to present bias (Chapman, Gamino and Mudar 2012; Galván 2012; Bettinger and Slonim 2007). For example, students are swayed by small, short-term college costs, such as application fees and the effort required to take the SAT or ACT; in a rational educational investment model, these costs would be dwarfed by long-term benefits and would not affect choices on the scale observed in many interventions that reduce these barriers (Oreopoulos and Ford 2019; Hoxby and Turner 2013; Goodman 2016; Pallais 2015; Bulman 2015).

Loss aversion, a phenomenon in which people feel a loss more strongly than an equal-sized gain, may cause students to underinvest in education to avoid the certain loss of time, effort, and money, even if the potential future gain is high (Kahneman and Tversky 1979). Similarly, debt aversion—an aversion that has no place in a traditional investment model - may prevent many students from borrowing to finance college (Field 2009; Caetano, Palacios and Patrinos 2019; Scott-Clayton 2012). Students from lower income backgrounds seem particularly prone to debt aversion (Baum and Schwartz 2015; Calender and Jackson 2005). Research has documented the important roles loss and debt aversion play in education and career decisions (see, for instance, Field 2009).

Finally, psychologists and sociologists point to the importance of social identity in decision-making. People tend to behave in ways consistent with their social identity and the norms of their social groups (Benjamin, Choi and Strickland, 2010). Making certain aspects of students' identities more salient (e.g. their academic achievement) may prompt them to make choices more in line with that part of their identity (e.g. applying to a selective college). Framing financial aid as a scholarship, rather than a need-based grant, calls attention to the high-achieving dimension of a student's identity, rather than their socioeconomic status (Avery and Hoxby, 2003).

All of the phenomena discussed above may be particularly important in contexts where there are many choices, and the decision-making process is complex. In the presence of information overload or

\footnotetext{
${ }^{9}$ Classical economic models acknowledge that information is costly to acquire, but in our context, the returns to a college degree are so large, and the opportunity costs of high school students so low, that it is virtually impossible to generate a scenario in which the costs of acquiring information outweigh the benefits.

${ }^{10}$ In this section, we draw heavily from several excellent review papers about the behavioral economics of education: Damgaard and Nielsen (2018); French and Oreopoulos (2017); Lavecchia, Liu and Oreopoulos (2016); Koch, Nafziger and Nielsen (2015); and Jabbar (2011).
} 
choice overload - when there are too many factors or too many options to fully consider-people tend to resort to heuristics or mental shortcuts to simplify the decision (Kahneman 2003). This could mean sticking to the status quo (which may be inaction) or picking the most prominent option, even if it is not the best one. College application and financial aid feature many choices and intense complexity. In this context, the default may mean choosing the nearest community college or regional university. Indeed, two thirds of all college students attend an institution within 25 miles of home, and nearly 85 percent attend an institution within 100 miles (authors' calculations using the National Postsecondary Student Aid Study, 2016 cohort).

In the presence of information overload, seemingly small changes to the environments in which people make choices can have large consequences. Interventions aimed at simplifying or assisting with the application and financial aid process, for instance, produce significant increases in student enrollment and persistence in college (e.g. Bettinger et al. 2012; Castleman and Page 2016). Additionally, changing the default option presented to people—without changing anything about the options available—has been shown to strongly influence the choice they make (Marx and Turner 2019; Pallais 2015; Johnson and Goldstein 2009; Beshears et al. 2013).

\section{DATA, SAMPle, AND RANDOMization}

Our target population is high-achieving, low-income students in Michigan. We identify these students using longitudinal, student-level administrative data, which contain the universe of students attending public high schools in the state. ${ }^{11}$

We identify high-achieving students based on high school GPA, which comes from student transcript data, and SAT score, which comes from mandatory, in-school 11th grade testing. ${ }^{12}$ Admissions officials at the University of Michigan set the GPA and score cutoffs; they are analogous to the criteria the school uses when gleaning prospective recruits from national data on ACT and SAT takers. Grades and scores do not determine admission; like most highly selective colleges, the University of Michigan uses multiple criteria, including extracurricular activities, to decide who gets in. Qualifying SAT scores start at 1100 while qualifying GPAs start at 3.3. Students with higher test scores faced a lower GPA threshold (and vice versa). Students in the sample had an average GPA of 3.8 and SAT of 1260.

We do not have information on family income. We identify low-income students using data on qualification for the federal subsidized-lunch program. Students with family income below 130 percent of the federal poverty line qualify for a free lunch, while those with incomes up to 185 percent of the poverty line can get a subsidized lunch. In 2018 , these thresholds were $\$ 32,630(\$ 46,435)$ for a family of four. Two-thirds of our sample qualifies for a free lunch and the remainder for a reduced-price lunch. ${ }^{13}$

Of the 100,000 juniors in Michigan's 1,000 public high schools, about 2,000 students in 500 schools

\footnotetext{
${ }^{11}$ Data come from the Michigan Department of Education (MDE) and the Michigan Center for Educational Performance and Information (CEPI).

${ }^{12}$ In the 2015-16 school year, which corresponds to the second cohort of our intervention, the state switched from using the ACT as part of the 11th grade standardized exam, to the SAT. We convert all ACT scores to SAT scores using official concordance tables.

${ }^{13}$ In Michigan, students automatically qualify for subsidized meals if their family receives means-tested benefits such as food stamps or TANF. Qualification occurs through a data match between the education and human services administrative systems.
} 
meet the income and academic criteria for our intervention each year: 2,108 students from 529 schools for the first cohort and 1,802 students from 497 schools for the second. ${ }^{14}$ As these numbers suggest, the typical school in Michigan has only a handful of high-achieving, low-income students and half of the schools have none. The modal school in our experimental sample has one student meeting the HAIL eligibility criteria (see Figure II).

Schools in the sample are widely dispersed throughout the state. While there are concentrations of schools in the major metropolitan areas, there are also many schools in the Upper Peninsula and in other rural areas (see Figure III).

\section{Figure II}

Typical School Has Few Eligible Students

First and Second HAIL Cohorts

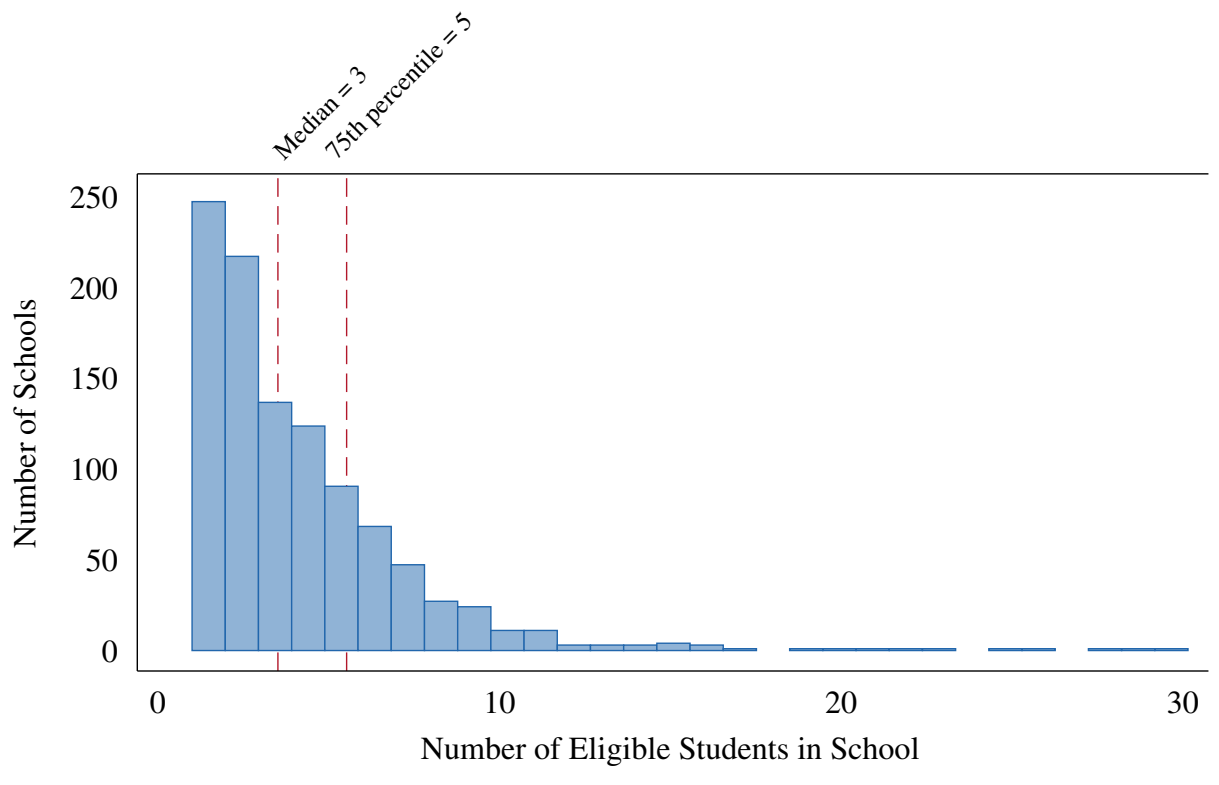

Source: Michigan administrative data Notes: Unit of analysis is the school-year.

\section{A Randomization}

We assign treatment status at the level of the high school. All students in a school who meet the income and academic criteria are assigned the same treatment status. We do this because we hypothesize treatment spillovers within schools, which (in the case of within-school randomization) would attenuate estimated effects toward zero. We stratify the sample (into four groups) by the number of HAIL-eligible students in each school and randomize within each stratum. ${ }^{15}$

\footnotetext{
${ }^{14}$ Pooling the two cohorts, 28,267 juniors met the academic criteria but not the income requirement, while 52,377 students met the income requirement but did not meet the achievement criteria.

${ }^{15}$ For the second cohort, schools that had newly entered the sample (because they had no qualifying students in the first cohort but did in the second) were randomly assigned using the same method. Similarly, some schools exited the sample during the second cohort. See Appendix Table I for details on how many schools were in the sample for each cohort.
} 


\section{Figure III}

HAIL Students Are Widely Dispersed Across Michigan

First and Second HAIL Cohorts

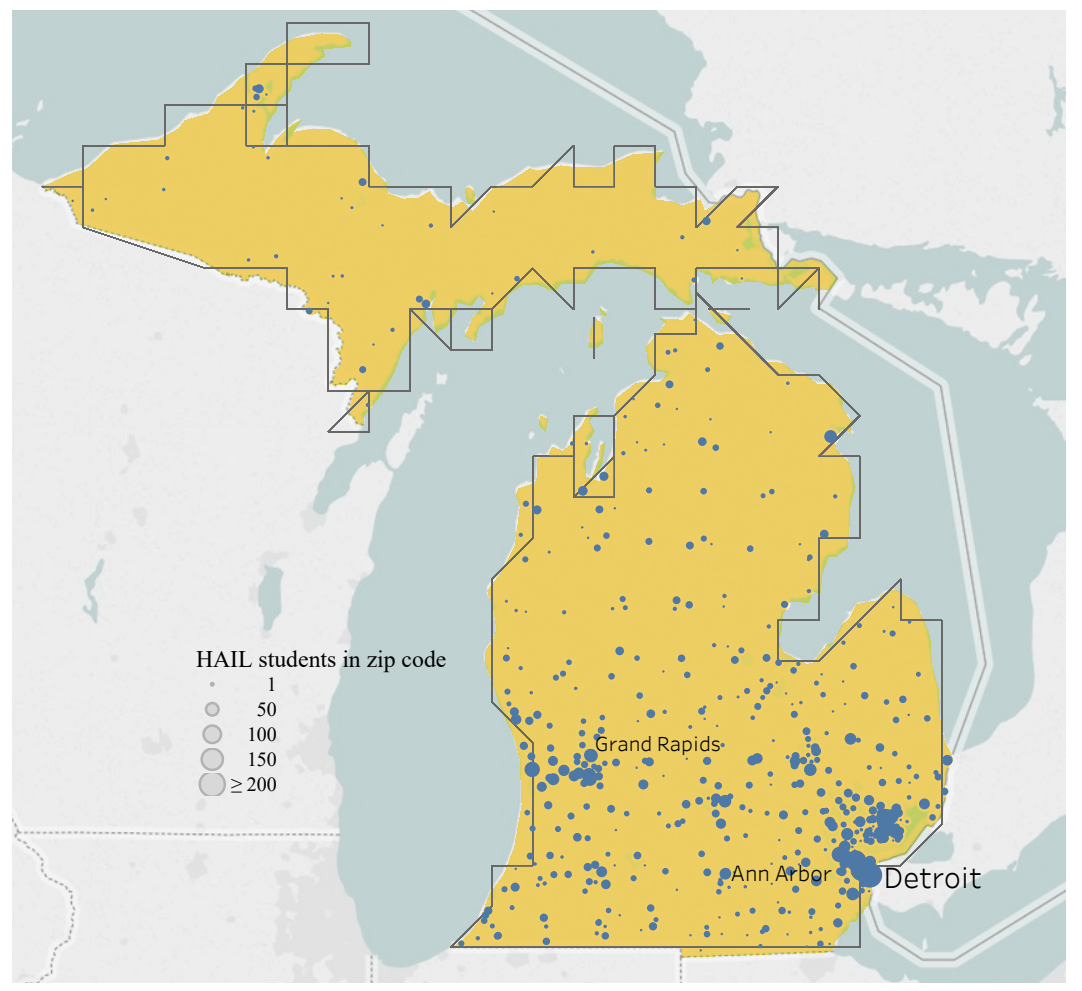

For the first cohort, the randomization resulted in 1,057 treated students and 1,051 control students in 262 treated schools and 267 control schools. In the second cohort, 875 students in 238 high schools were in the treatment group, while 927 students in 259 high schools were in the control group.

Sample characteristics are shown in Table II. The table shows tests for balance (within each cohort-stratum) between treatment and control groups. Forty percent of the schools in the treatment and control groups are in the Southeast region of the state, near Ann Arbor, Lansing, and Detroit. Another 14 percent of schools are in the largely rural Upper Peninsula. The remaining schools are scattered across the Lower Peninsula, with many concentrated in the Grand Rapids area. Over half the schools are rural, a third are suburban, and the remainder urban.

The overwhelming majority (84 percent) of sample students are white or Asian, reflecting the strong correlation (in Michigan and the US) between academic achievement and race. Nine percent are black and seven percent Hispanic, American Indian, or native Hawaiian. ${ }^{16}$ A majority are female (59 percent). All of these statistics track patterns of academic achievement in the state.

A glance through the table shows balance on nearly all characteristics. The only significant imbalance is in schools' historical rate of application to the University of Michigan. At treated schools, 5.5 percent of

\footnotetext{
${ }^{16}$ We group students into three race/ethnicity categories: white or Asian, black, and other. Race categories are mutually exclusive. "Other" includes Hispanics, American Indians, Alaska Natives, Native Hawaiians, and other Pacific Islanders. Students are coded as Hispanic if they identify as Hispanic, regardless of race. For students of multiple races, a single race category is assigned according to the following hierarchy: black, Native American, Asian, Hawaiian/Pacific Islander, white.
} 
students applied to the University of Michigan in 2015, before the experiment. At control schools the rate was 6.7 percent. (Due to data limitations, this historical application rate is for all of a school's students, not just those who are low-income and high-achieving.) We find no other significant differences between the treatment and control group using two-way t-tests. We test the sensitivity of results to controlling for covariates.

\section{INTERVENTION}

We designed the treatment to address the behavioral barriers discussed earlier. We drew on insights from previous interventions attempting to reduce income-based gaps in college choices, as well as the behavioral economics literature on decision-making.

Students in the treatment group received personally-addressed packets at their homes in the first week of September of their senior year of high school. Students in the control group received materials typically sent to potential applicants by the University of Michigan (including booklets describing the school and its financial aid).

The treatment materials, designed by admissions staff, were large, glossy, and brightly colored in the university's signature "maize and blue" coloring. We recommended that they be eye-catching, and clearly from the University of Michigan, to reduce the likelihood that students would discard the packets without opening them (see pictures in Appendix A.1). In previous interventions, mailings sent in plain envelopes from an unrecognized source were largely ignored or disregarded as fraudulent (Hoxby and Turner 2013; Goldrick-Rab et al. 2016).

Inside the packet, a letter from the president of the University of Michigan praised the recipients' academic achievement and encouraged them to apply for admission. The letter then guaranteed four years of tuition and fees if the student were accepted. The value of this offer was also expressed in dollar terms $(\$ 60,000)$. The offer was framed as a scholarship, rather than a need-based grant. In fact, the student's low-income status was referenced nowhere in the mailing. The mailing stated prominently that applicants did not have to complete financial aid forms (the Free Application for Federal Student Aid, FAFSA, and the College Scholarship Service Profile) in order to receive this scholarship; the only condition was admission to the University of Michigan. Because the aid staff were concerned that this guarantee would discourage students from completing aid forms, which would almost certainly qualify them for even more aid, students were encouraged (in smaller type) to fill out the FAFSA and Profile. Eliminating the requirement to fill out the forms at the time of applications was intended to address a key behavioral bias: administrative burdens incurred in the present weigh heavily relative to uncertain benefits in the future (Oreopoulos and Ford 2019; Hoxby and Turner 2013; Goodman 2016; Pallais 2015; Bulman 2015).

A large, bright insert reiterated the scholarship offer in a format that resembled a coupon. Additional "coupons" guaranteed that fees would be waived for all applications for admission and aid. These physical coupons were intended to make the offers feel as concrete as possible.

The packet also contained materials sent to all potential applicants: a flyer describing application and 
Table II

Balance Table: Selected School Characteristics

First and Second HAIL Cohorts

\begin{tabular}{|c|c|c|c|}
\hline \multirow[b]{2}{*}{ Characteristic } & \multicolumn{2}{|c|}{ Mean } & \multirow[b]{2}{*}{ P-value } \\
\hline & Control schools & Treated schools & \\
\hline \multicolumn{4}{|l|}{ School characteristics } \\
\hline Upper Peninsula & $\begin{array}{c}0.150 \\
(0.016)\end{array}$ & $\begin{array}{c}0.130 \\
(0.015)\end{array}$ & 0.344 \\
\hline West Central & $\begin{array}{c}0.449 \\
(0.022)\end{array}$ & $\begin{array}{c}0.476 \\
(0.022)\end{array}$ & 0.359 \\
\hline Southeast & $\begin{array}{c}0.401 \\
(0.021)\end{array}$ & $\begin{array}{c}0.394 \\
(0.022)\end{array}$ & 0.788 \\
\hline Suburban & $\begin{array}{c}0.340 \\
(0.021)\end{array}$ & $\begin{array}{c}0.360 \\
(0.021)\end{array}$ & 0.537 \\
\hline City & $\begin{array}{c}0.129 \\
(0.015)\end{array}$ & $\begin{array}{c}0.100 \\
(0.013)\end{array}$ & 0.148 \\
\hline Rural & $\begin{array}{c}0.530 \\
(0.022)\end{array}$ & $\begin{array}{c}0.540 \\
(0.022)\end{array}$ & 0.718 \\
\hline \# of 11th grade students in school & $\begin{array}{c}189.1 \\
(6.188)\end{array}$ & $\begin{array}{c}175.1 \\
(6.126)\end{array}$ & 0.055 \\
\hline \# of HAIL students in school & $\begin{array}{c}3.8 \\
(0.140)\end{array}$ & $\begin{array}{c}3.9 \\
(0.163)\end{array}$ & 0.649 \\
\hline UM application rate in 2015 & $\begin{array}{c}0.067 \\
(0.004)\end{array}$ & $\begin{array}{c}0.055 \\
(0.004)\end{array}$ & 0.016 \\
\hline \multicolumn{4}{|l|}{ Student characteristics } \\
\hline Proportion female & $\begin{array}{c}0.571 \\
(0.015)\end{array}$ & $\begin{array}{c}0.605 \\
(0.015)\end{array}$ & 0.112 \\
\hline Proportion white or Asian & $\begin{array}{c}0.834 \\
(0.013)\end{array}$ & $\begin{array}{c}0.844 \\
(0.012)\end{array}$ & 0.576 \\
\hline Proportion black & $\begin{array}{c}0.094 \\
(0.011)\end{array}$ & $\begin{array}{c}0.087 \\
(0.010)\end{array}$ & 0.618 \\
\hline Proportion other race/ethnicity & $\begin{array}{c}0.072 \\
(0.009)\end{array}$ & $\begin{array}{c}0.069 \\
(0.008)\end{array}$ & 0.803 \\
\hline Proportion free lunch eligible & $\begin{array}{c}0.709 \\
(0.014)\end{array}$ & $\begin{array}{c}0.692 \\
(0.015)\end{array}$ & 0.459 \\
\hline $\begin{array}{l}\text { Proportion reduced-price lunch } \\
\text { eligible }\end{array}$ & $\begin{array}{c}0.291 \\
(0.014)\end{array}$ & $\begin{array}{c}0.308 \\
(0.015)\end{array}$ & 0.459 \\
\hline Average SAT (or equivalent) & $\begin{array}{c}1254 \\
(2.690)\end{array}$ & $\begin{array}{c}1260 \\
(2.896)\end{array}$ & 0.194 \\
\hline Average GPA & $\begin{array}{c}3.82 \\
(0.006)\end{array}$ & $\begin{array}{c}3.83 \\
(0.006)\end{array}$ & 0.208 \\
\hline Number of school-years & 526 & 500 & 1,026 \\
\hline Number of students & 1,978 & 1,932 & 3,910 \\
\hline
\end{tabular}

Source: Michigan administrative data and University of Michigan Office of Enrollment Management data.

Notes: All analyses done at the school-year level. P-values are from a t-test of the coefficient on treatment status from a regression of the characteristic on treatment and strata dummies. "Other race/ethnicity" includes Hispanic, American Indian or Alaska Native, and Native Hawaiian or other Pacific Islander students. 
admissions and brochures describing the University of Michigan. These materials encouraged students to apply to the University of Michigan by November 1, which is the "early action" deadline for the school. The University of Michigan admits most of its incoming class through early action, so students have the best chance of being admitted if they apply by that date. Students would still be eligible for the scholarship if they applied by the standard deadline of February 1, however. ${ }^{17}$

Information was also mailed to parents, and emailed to principals, of eligible students (see Appendices A.2 and A.3). Letters to parents, mailed two weeks after the student packets, described the scholarship and encouraged them to help their children apply. Communications with principals, sent in late August, explained the program, listed eligible students, and asked the principal to transmit the information to school staff who supported students in their college applications.

\section{EMPIRICAl STRATEgY}

We evaluate the effect of the HAIL scholarship on application, admission, enrollment, and persistence at the University of Michigan using internal data from the university. To measure enrollment and persistence at institutions nationwide, and to measure college selectivity, we rely on National Student Clearinghouse (NSC) data, available for all students in the treatment and control groups. We compare the outcomes of treatment and control students, estimating the following models by ordinary least squares (OLS):

$$
\begin{gathered}
Y_{j t}=\beta_{0}+\beta_{1} D_{j}+\beta_{2} S_{j t}+u_{j t} \\
Y_{j t}=\gamma_{0}+\gamma_{1} D_{j}+\gamma_{2} S_{j t}+\gamma_{3} Z_{j t}+u_{j t}
\end{gathered}
$$

where $Y_{j t}$ is an outcome of interest at school $j$ for cohort $t$. We collapse the individual student data to the school-cohort level and conduct analysis on these means. ${ }^{18} D_{j}$ is an indicator variable equal to one if the school is randomized to the treatment group and zero if the school is randomized to the control group (note that schools keep their randomization status from the first cohort to the second cohort). $S_{j t}$ is a vector of strata-by-year dummies.

$\beta_{1}$ and $\gamma_{1}$ are the parameters of interest and measure the causal effect of being randomized into the treatment group, i.e. the estimated effect of the Intent to Treat (ITT). These parameters represent the treatment effect on the outcomes of interest, with schools weighted equally. ${ }^{19}$

Since we observe the outcomes for all students, and therefore all schools, there is no attrition due to non-response. We do not observe whether a student actually receives the information packet (i.e. is effectively treated), and students assigned to the control group cannot be treated, so we do not adjust for non-compliance.

As described in our pre-analysis plan, we conduct subgroup analyses to check for heterogeneity in the

\footnotetext{
${ }^{17}$ Many selective colleges have an early application window for students who are particularly interested in that school. Some schools accept early applications only from the students who agree to enroll if admitted ("early decision"). Others, like the University of Michigan, inform students of their admission by the beginning of January but do not require students to accept the early offer ("early action").

${ }^{18}$ Unless otherwise noted, we conduct all analyses at the school-year level since that is the level of treatment; results are consistent when conducted at the student-level.

${ }^{19}$ Estimates are similar when weighted by the number of sample students in each school.
} 
treatment effect. ${ }^{20}$ These subgroup analyses help to identify the potential mechanisms through which HAIL affected application and enrollment. Previous research suggests that low-income, high-achieving students who have few similar peers are less likely to attend selective institutions than those who are surrounded by similar peers (Hoxby and Avery 2012). Of particular interest is whether the HAIL scholarship was effective in raising application and enrollment rates among these isolated students (as found in a previous intervention designed to increase application rates of low-income students to selective institutions, Hoxby and Turner 2013). We proxy for isolation by region (Southeast, West Central, or Upper Peninsula), urbanicity (city, suburban, or town/rural), and the number of HAIL eligible students in the school.

Similarly, research has suggested that a high school's prior ties with a school predicts whether a student will attend (Hoxby and Avery 2012). We test this hypothesis by evaluating heterogeneous treatment effects as a function of schools' baseline application and enrollment rates at University of Michigan at Ann Arbor.

Additionally, we evaluate heterogeneity by gender (male vs. female), race (white/Asian, black, other), academic achievement (SAT score and GPA), and two measures of economic disadvantage. Finally, we summarize our heterogeneity analyses with a single index predicting the likelihood that a student would have attended a selective college in the absence of the intervention.

\section{RESUlts}

\section{A Evidence of HAIL Awareness from Website Activity}

If we were to find no effect of the intervention, it is important to understand whether the materials went unread, or if the message they contained was ineffective in changing behavior. We therefore examine a crude measure of whether students and parents opened and read the personalized mailings. We assigned each student a personalized web address and included it in the student packets, along with encouragement to log onto a website that described in greater detail the HAIL Scholarship and University of Michigan. To encourage students to go to the site, the packet offered them a free University of Michigan t-shirt.

About 40 percent of students offered HAIL visited the website at least once. Among students who visited the website, the average number of views was 5.5 with a median of three. This provides a lower bound on the number of students who read the packet, as many may have read the packet but not visited the website.

First-time visits to the website are concentrated in the days after student and parent letters were mailed (Figure IV). One spike occurs a few days after the student letter was mailed and another after the parent letter was mailed. This suggests that some parents prodded their children to log onto the website, since only the student packet contained login instructions. ${ }^{21}$

\footnotetext{
${ }^{20}$ We show tests for balance in these subgroups in Appendix Table III. See https://www.socialscienceregistry.org/trials/1831 for our pre-analysis plan.

${ }^{21}$ The pattern is similar for the second cohort, though (due to delays in printing packets) student and parent letters were sent only three days apart (see Appendix Figure Ic). In addition to first-time page views, we also track total page views of personalized HAIL websites. See Appendix Figures Ib and Id for graphs of the total number of visits to HAIL websites for the first and second HAIL cohorts, respectively.
} 
Figure IV

First-time Visits to HAIL Webpages

First HAIL Cohort

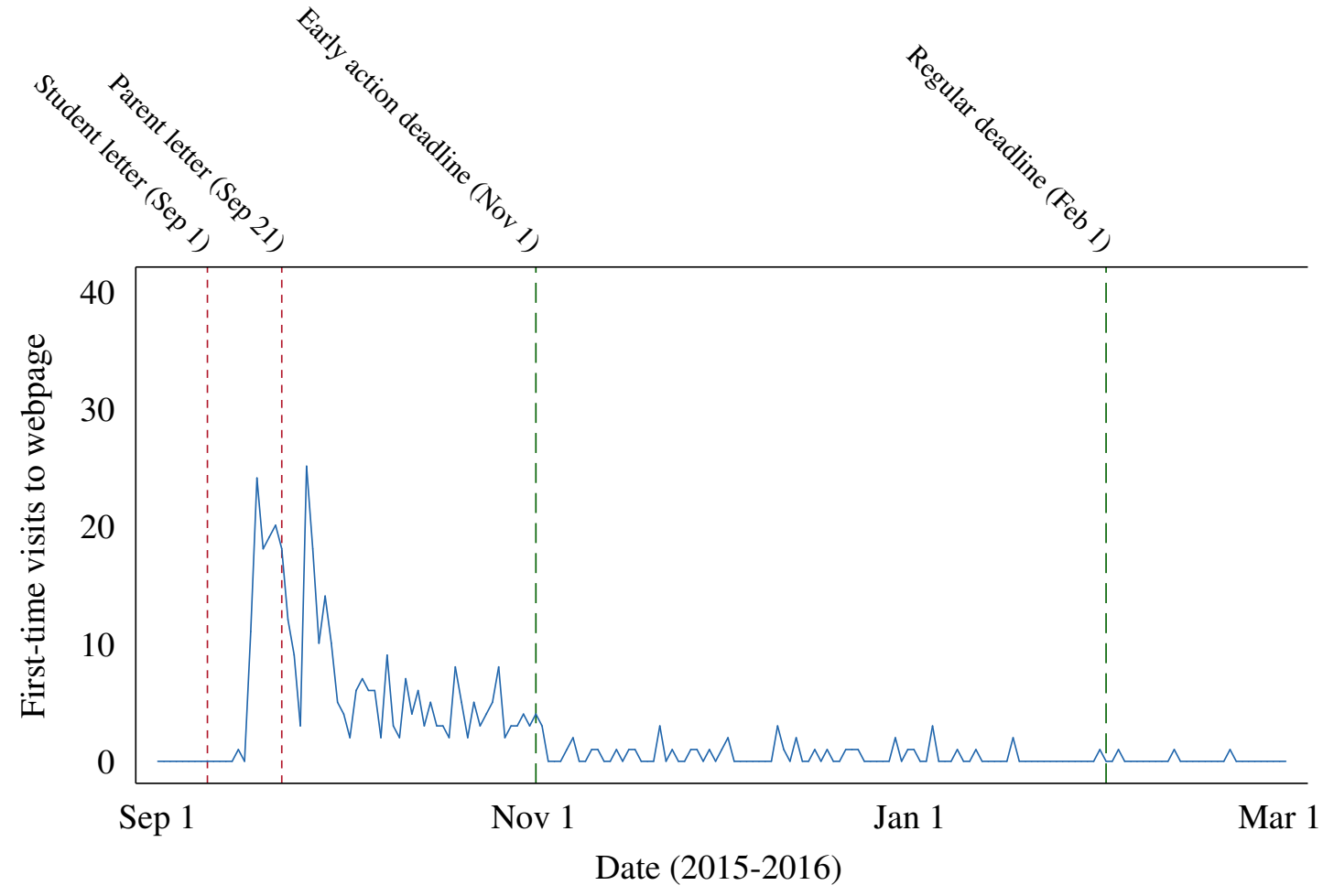

Source: University of Michigan Office of Enrollment Management data

Notes: Unit of analysis is a first-time visit to the personalized URL associated with a treated HAIL student, aggregated by date. 


\section{B Application, Admission, and Enrollment at the University of Michigan}

Students in treated schools were substantially more likely to apply to, gain admission to, and enroll at the University of Michigan at Ann Arbor than those in control schools (see Table III for regression estimates and Appendix Figure II for treatment and control means). ${ }^{22}$

At control schools, 26 percent of low-income, high-achieving students applied to the University of Michigan, compared to 68 percent at treatment schools. That is, the treatment increased the application rate by 42 percentage points. Results were virtually identical across the two cohorts. ${ }^{23}$

The intervention materials encouraged students to apply by the early action deadline of November $1 .^{24}$ Early application is a signal of a student's commitment to a school, so the attractiveness of the scholarship offer could have changed the timing of application for inframarginal as well as marginal students. Early application is already a popular choice for University of Michigan applicants; of students in the control group who applied, around three-quarters applied early action. We find that the intervention did not change this proportion, with three-quarters of the effect on application coming from students induced to apply early and the remaining quarter from students who were moved to apply regular decision. (See Appendix Table IV for full results on application timing.) Though we cannot observe application behavior at schools other than the University of Michigan, this suggests that the HAIL offer did not change the level of commitment to the school among those who applied.

These large differences in application rates translated into large differences in admissions rates. The (unconditional) admission rate was 15 percent in control schools and 32 percent in treated schools, a treatment effect of 17 percentage points. This is the net effect of the treatment on the joint likelihood of applying to and being admitted to the University of Michigan.

We do not have experimental evidence of the effect of the intervention on admission conditional upon application, because application is affected by the treatment. Another way to put this is that treatment is not randomly assigned among applicants. However, comparing conditional admission rates gives a sense of the qualifications of the marginal applicant. Of the 589 control students who applied, 52.5 percent were accepted; of the 1,306 treated students who applied, 45.6 percent were accepted (see Appendix Table V). Note that the overall acceptance rate to the University of Michigan was 28.6 percent in 2016-17, indicating that the applicants in our sample (including those induced to apply) are more qualified than the average applicant. ${ }^{25}$

Students in the treatment group were significantly more likely to enroll at the University of Michigan than those in the control group. ${ }^{26}$ The (unconditional) enrollment rate for students in the control schools is

\footnotetext{
${ }^{22}$ Reported values in all results using application, admission, and enrollment data from the University of Michigan's Office of Enrollment Management have changed slightly since the December, 2018 NBER working paper version of this study. This was due to uncovering a small number of students who had been assigned duplicate administrative data IDs, and who we were therefore incorrectly coding as not applying to (or subsequently enrolling at) the University of Michigan. This affects Tables III, IV, V, VI, VII, VIII, and IX and Figures V and VI but none of our substantive conclusions.

${ }^{23}$ We pool the two cohorts for most analyses; results separately by cohort are available upon request.

${ }^{24}$ Students who apply by the early action deadline are typically notified of their admission status by the end of the calendar year. While early decision deadlines are binding — students must enroll if accepted-the University of Michigan uses an early action deadline, which does not compel students to enroll if admitted.

${ }^{25}$ Source: University of Michigan Office of Enrollment Management data. In the subsequent year, which corresponds to the second cohort of the HAIL intervention, the overall acceptance rate was 26.5 percent.

${ }^{26}$ In addition to our standard sampling-based inference, we test the likelihood of obtaining our estimated treatment effect on University
} 
12 percent while in the treatment schools it is 27 percent. This translate into an increased enrollment of about 150 low-income students for each of the two cohorts.

Treatment effects estimated by differences in means (shown in Appendix Figure II), a regression controlling for strata (Model (1), shown in the first column of Table III), and a regression controlling for strata and additional school covariates (Model (2), shown in the second column of Table III) are virtually identical. $^{27}$

\section{Table III}

Estimated Effect of HAIL Scholarship on UM Application, Admission, and Enrollment First and Second HAIL Cohorts

\begin{tabular}{|c|c|c|c|}
\hline Outcome & \multicolumn{2}{|c|}{ Treatment effect } & $\begin{array}{c}\text { Control } \\
\text { mean }\end{array}$ \\
\hline Applied & $\begin{array}{c}0.422 \\
(0.021)\end{array}$ & $\begin{array}{c}0.419 \\
(0.019)\end{array}$ & 0.259 \\
\hline Admitted & $\begin{array}{c}0.176 \\
(0.019)\end{array}$ & $\begin{array}{c}0.164 \\
(0.017)\end{array}$ & 0.149 \\
\hline Enrolled & $\begin{array}{c}0.151 \\
(0.018)\end{array}$ & $\begin{array}{c}0.143 \\
(0.016)\end{array}$ & 0.117 \\
\hline $\begin{array}{l}\text { Strata dummies } \\
\text { Covariates } \\
\text { Number of school-years } \\
\text { Number of students }\end{array}$ & $X$ & $\begin{array}{r}X \\
26 \\
10\end{array}$ & \\
\hline
\end{tabular}

Source: Michigan administrative data and University of Michigan Office of Enrollment Management data.

Notes: All analyses done at the school-year level. Covariates include all characteristics listed in Appendix Table II. Robust standard errors reported. Application, admission and enrollment measured in the summer and fall following expected high school graduation. Admission and enrollment are unconditional on application.

\section{Mechanisms: Isolation and Disconnection}

Low-income, high-achieving students isolated from other high-achieving peers in rural areas are less likely to apply to selective institutions than those living in urban areas with a higher concentration of such peers (Hoxby and Avery 2012). Indeed, among control schools, application, admission, and enrollment rates were approximately twice as high in the Southeast (which includes Detroit and Ann Arbor, where the University of Michigan is located), compared to the West Central (a mix of rural and urban areas such as Grand Rapids) and the Upper Peninsula (a rural area).

HAIL equalized student outcomes across region and urbanicity, with the largest treatment effects in the

of Michigan enrollment (as well as other key enrollment margins) using randomization-based inference. In this approach, randomness comes from assignment of a fixed number of units to treatment rather than sampling from a super-population. The conclusions are unchanged (and the p-values are nearly identical): the intervention treatment effects we find are highly unlikely to have occurred by chance. See Appendix B for details.

${ }^{27}$ For the remainder of the paper, we report treatment effects estimated controlling for strata only. Regression results including all controls are in Appendix Tables VII, IX through XI, and XIII through XVI. 
regions with the lowest control means (see Table IV for regression treatment effect estimates and Appendix Figures IV and V for treatment and control means). For the application margin, the treatment effect was largest in the West Central region (47 percentage points) and smallest in the Southeast (38 percentage points).

Reflecting the regional pattern, effects were largest in the rural areas, where control means are lowest. In the control group, the enrollment rate is 22 percent in the urban areas and 8 percent in rural schools; the enrollment effects were 12 and 18 percentage points, respectively. HAIL reduced the gap in enrollment rates between urban and rural schools by half: from 14 percentage points in the control group to 7 percentage points in the treatment group. The outsized impact of the treatment on students in more rural areas of the state as well as locales farther from University of Michigan is consistent with the treatment compensating for student isolation, a potential mechanism we test in greater detail below.

Table IV

Estimated Effect of HAIL Scholarship on UM Application, Admission, and Enrollment by Geography First and Second HAIL Cohorts

\begin{tabular}{|c|c|c|c|c|c|c|}
\hline & \multicolumn{3}{|c|}{ Panel A. Region } & \multicolumn{3}{|c|}{ Panel B. Urbanicity } \\
\hline & Southeast & $\begin{array}{c}\text { West } \\
\text { Central }\end{array}$ & $\begin{array}{c}\text { Upper } \\
\text { Peninsula }\end{array}$ & Suburb & City & $\begin{array}{c}\text { Town } \\
\text { or Rural }\end{array}$ \\
\hline Applied & $\begin{array}{c}0.378 \\
(0.031) \\
{[0.364]}\end{array}$ & $\begin{array}{c}0.466 \\
(0.029) \\
{[0.2]}\end{array}$ & $\begin{array}{c}0.398 \\
(0.059) \\
{[0.156]}\end{array}$ & $\begin{array}{c}0.384 \\
(0.031) \\
{[0.336]}\end{array}$ & $\begin{array}{c}0.318 \\
(0.062) \\
{[0.464]}\end{array}$ & $\begin{array}{c}0.487 \\
(0.028) \\
{[0.159]}\end{array}$ \\
\hline Admitted & $\begin{array}{c}0.159 \\
(0.031) \\
{[0.202]}\end{array}$ & $\begin{array}{c}0.187 \\
(0.026) \\
{[0.116]}\end{array}$ & $\begin{array}{c}0.187 \\
(0.054) \\
{[0.105]}\end{array}$ & $\begin{array}{c}0.156 \\
(0.029) \\
{[0.164]}\end{array}$ & $\begin{array}{c}0.061 \\
(0.066) \\
{[0.319]}\end{array}$ & $\begin{array}{c}0.228 \\
(0.026) \\
{[0.097]}\end{array}$ \\
\hline Enrolled & $\begin{array}{c}0.145 \\
(0.029) \\
{[0.167]}\end{array}$ & $\begin{array}{c}0.152 \\
(0.024) \\
{[0.085]}\end{array}$ & $\begin{array}{c}0.176 \\
(0.051) \\
{[0.08]}\end{array}$ & $\begin{array}{c}0.133 \\
(0.027) \\
{[0.14]}\end{array}$ & $\begin{array}{c}0.117 \\
(0.061) \\
{[0.221]}\end{array}$ & $\begin{array}{c}0.183 \\
(0.024) \\
{[0.078]}\end{array}$ \\
\hline $\begin{array}{l}\text { Number of school-years } \\
\text { Number of students }\end{array}$ & $\begin{array}{c}408 \\
1,848\end{array}$ & $\begin{array}{c}474 \\
1,646\end{array}$ & $\begin{array}{l}144 \\
416\end{array}$ & $\begin{array}{c}359 \\
1,784\end{array}$ & $\begin{array}{l}118 \\
530\end{array}$ & $\begin{array}{c}549 \\
1,596\end{array}$ \\
\hline
\end{tabular}

Source: Michigan administrative data and University of Michigan Office of Enrollment Management data.

Notes: All analyses done at the school-year level. Coefficients are from separate regressions of outcome on treatment status and strata dummies, estimated on the subgroup. Robust standard errors reported in parentheses. Control mean for subgroup in brackets. Application, admission and enrollment measured in the summer and fall following expected high school graduation. Admission and enrollment are unconditional on application.

Building on the results by region and urbanicity, we additionally test how HAIL affected isolated students by estimating variation in the treatment effects by baseline, school-level application and enrollment rates to the University of Michigan. We also estimate heterogeneity by the number of HAIL-eligible students in the school (see Table V and Figure V). ${ }^{28}$ We estimate heterogeneity by these school-level characteristics by interacting the treatment indicator with linear terms for the baseline application/enrollment rates and the

\footnotetext{
${ }^{28}$ Prior University of Michigan application and enrollment rates are for the graduating class of 2015. The number of HAIL-eligible students in each high school is cohort-specific.
} 
number of HAIL students in each school. For ease of interpretation, we present treatment effects in Table V calculated for the 25 th percentile, median, and 75 th percentile of each measure of isolation. ${ }^{29}$

Though treatment effects were large for schools across the distribution of prior UM application rates, we find slightly larger effects for students who were more disconnected from other high-achieving peers and selective colleges. Treatment effects are largest in schools that previously had no students apply to or enroll at the University of Michigan. The effect on application is 47 percentage points for high schools at the 25th percentile of baseline application rates (this is a school where less than 2 percent of students applied). For high schools at the 75th percentile (where 7 percent applied) the effect is 42 percentage points. We find similar patterns for admission and enrollment, though the interaction terms were not statistically significant on these margins. Results are quite similar when we use prior enrollment rates rather than prior application rates (Panel $\mathrm{B}$, Table V).

We also examine treatment effect heterogeneity by the number of HAIL students in the school. In assigning schools to treatment, we stratified on this characteristic because we hypothesized that the number of similarly high-achieving but low-income peers in a school would affect students' baseline propensity to apply to a selective school. The results (Panel C of Table V, Figure V) suggest isolation plays an important role in undermatch: treatment effects are largest at schools with the fewest HAIL-eligible students. For a school at the 25th percentile of this measure (two HAIL-eligible students), the effect on application is 45.1 percentage points. For a school at the 75 th percentile (five HAIL-eligible students), the effect is 40.1 percentage points. Similarly, on the enrollment margin, the treatment effect is 16.6 percentage points for schools at the 25th percentile, and 14 percentage points for schools at the 75 th percentile. Together, the results in Table V suggest that the HAIL scholarship had slightly larger effects on students who were the sole recipient of the HAIL scholarship in their schools and among students who attended high schools with weak prior connections to the University of Michigan.

Finally, we report treatment effects by an additional measure of connection to the University of Michigan. When students take the SAT as part of the 11th grade exam (before treatment), they can send their scores to up to four colleges. In the control group, students who sent their scores to the University of Michigan were nearly three times more likely to apply (42 versus 16 percent) and nearly four times more likely to enroll (20 versus 6 percent) than peers who did not send their scores (Table VI). Proportionally, treatment effects were much larger among students who did not send their scores to the University of Michigan, resulting in a tripling of their application and enrollment rates.

Collectively, these results confirm that our up-front, unconditional scholarship offer changed behavior most for students who were initially the most isolated and disconnected from-and therefore least likely to apply to- the University of Michigan.

\footnotetext{
${ }^{29}$ For estimated regression coefficients, see Appendix Table VIII.
} 
Table V

Estimated Effect of HAIL Scholarship on UM Application, Admission, and Enrollment by Historical School Connection to UM and Number of HAIL Students

First and Second HAIL Cohorts

\begin{tabular}{|c|c|c|c|c|}
\hline & \multicolumn{3}{|c|}{ Percentile of interacted variable } & \multirow{2}{*}{$\begin{array}{l}\text { P-value on } \\
\text { interaction } \\
\text { term }\end{array}$} \\
\hline & 25 th & Median & 75th & \\
\hline \multicolumn{5}{|c|}{ Panel A. Prior School-Level UM Application Rate } \\
\hline \multicolumn{5}{|l|}{ Estimated treatment effect } \\
\hline Applied & 0.47 & 0.451 & 0.419 & 0.000 \\
\hline Admitted & 0.197 & 0.19 & 0.179 & 0.152 \\
\hline Enrolled & 0.166 & 0.162 & 0.154 & 0.349 \\
\hline Prior application rate at percentile & 0.019 & 0.038 & 0.071 & \\
\hline \multicolumn{5}{|c|}{ Panel B. Prior School-Level UM Enrollment Rate } \\
\hline \multicolumn{5}{|l|}{ Estimated treatment effect } \\
\hline Applied & 0.486 & 0.45 & 0.413 & 0.000 \\
\hline Admitted & 0.201 & 0.189 & 0.177 & 0.13 \\
\hline Enrolled & 0.171 & 0.162 & 0.152 & 0.233 \\
\hline Prior enrollment rate at percentile & 0 & 0.013 & 0.027 & \\
\hline \multicolumn{5}{|c|}{ Panel C. Number of HAIL Students in School } \\
\hline $\begin{array}{l}\text { Estimated treatment effect } \\
\text { Applied }\end{array}$ & 0.451 & 0.435 & 0.401 & 0.000 \\
\hline Admitted & 0.192 & 0.183 & 0.164 & 0.036 \\
\hline Enrolled & 0.166 & 0.158 & 0.14 & 0.032 \\
\hline \# of HAIL students at percentile & 2 & 3 & 5 & \\
\hline
\end{tabular}

Source: Michigan administrative data and University of Michigan Office of Enrollment Management data.

Notes: All analyses done at the school-year level. Results are from a regression of the outcome on treatment, the named variable, the interaction of the two, and strata dummies. Robust standard errors estimated. Estimated treatment effects at percentiles calculated by adding the estimated coefficient on treatment to the product of the estimated interaction term and the value of the interacted variable at the percentile. Prior UM application rate and enrollment rates are for the graduating class of 2015. 


\section{Figure V}

Estimated Effect of HAIL Scholarship on UM Application, Admission, and Enrollment by Number of HAIL Students in School

First and Second HAIL Cohorts

(a) Applied

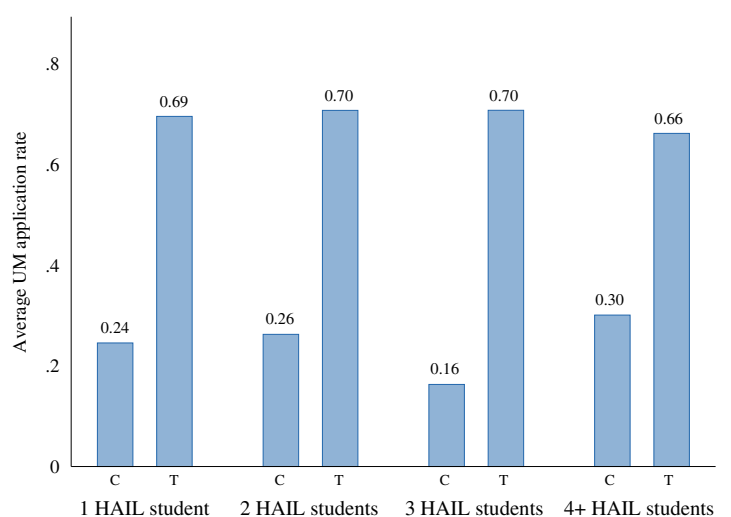

(b) Admitted

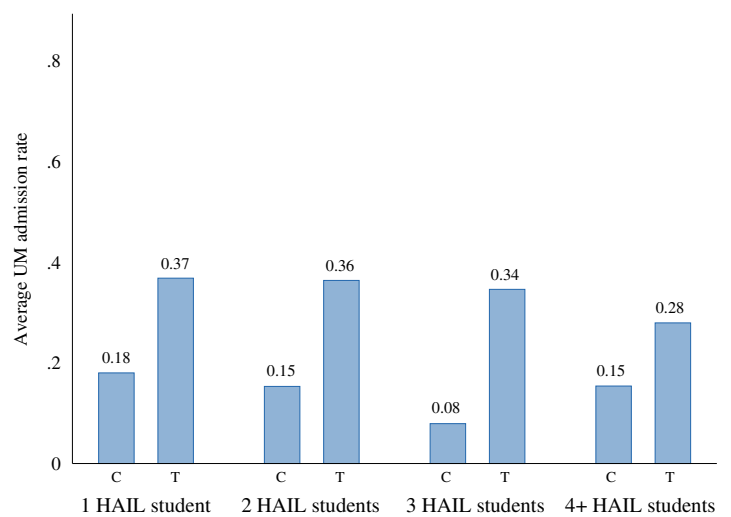

(c) Enrolled

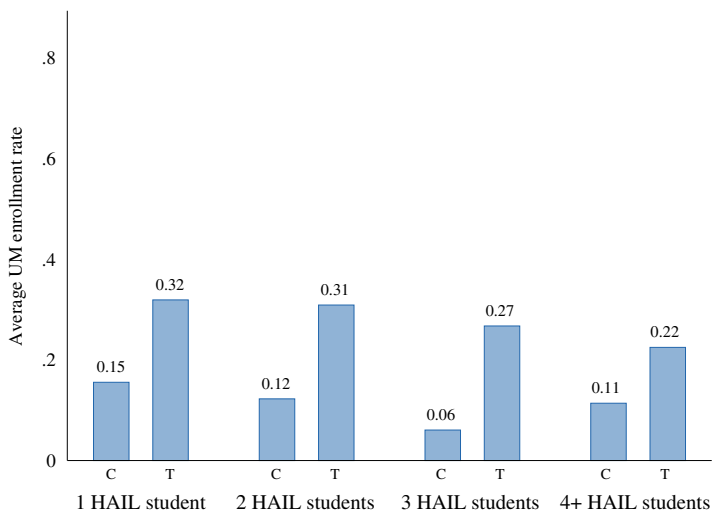

Source: Michigan administrative data and University of Michigan Office of Enrollment Management data.

Notes: All analyses done at the school-year level. Application, admission and enrollment measured in the summer and fall following expected high school graduation. Admission and enrollment are unconditional on application. Schools with 1 HAIL student make up 24 percent of sample, while schools with 2, 3, and 4 or more HAIL students represent 21 percent, 13 percent, and 42 percent of the sample, respectively. 


\section{Table VI}

Estimated Effect of HAIL Scholarship on UM Application, Admission, and Enrollment by Pre-Treatment Interest in UM

First and Second HAIL Cohorts

\begin{tabular}{lcc}
\hline & Sent SAT Scores to UM & Did Not Send Scores \\
\hline \hline Applied & 0.372 & 0.437 \\
& $(0.029)$ & $(0.023)$ \\
& {$[0.421]$} & {$[0.161]$} \\
Admitted & 0.169 & 0.165 \\
& $(0.030)$ & $(0.019)$ \\
& {$[0.255]$} & {$[0.081]$} \\
Enrolled & 0.157 & 0.140 \\
& $(0.028)$ & $(0.018)$ \\
& {$[0.199]$} & {$[0.059]$} \\
Number of school-years & 663 & 882 \\
Number of students & 1,514 & 2,396 \\
\hline
\end{tabular}

Source: Michigan administrative data and University of Michigan Office of Enrollment Management data.

Notes: All analyses done at the school-year level. Coefficients are from separate regressions of school-subgroup-level outcome rate on treatment status and strata dummies. Robust standard errors reported in parentheses. Control mean for subgroup in brackets. UM application, admission and enrollment measured in the summer and fall following expected high school graduation. Admission and enrollment are unconditional on application.

\section{Mechanisms: Extent of Economic Disadvantage}

Though all students in our sample are from low-income households, they vary in the degree of their economic disadvantage. We might expect larger treatment effects among the most disadvantaged students, who face stricter constraints than their peers.

While we lack income data, we have a few ways of identifying the most disadvantaged students. We can distinguish between students who received a free meal in school (whose family income is below 130 percent of the federal poverty line) and those who received a reduced-price meal (who have family income between 130 and 185 percent of the federal poverty line). Additionally, we follow the finding of Michelmore and Dynarski (2017) that students who spend more years eligible for subsidized school meals come from families with the lowest incomes. We therefore group students by whether they were eligible for free or reduced-price lunch in all of their pre-treatment high school years (grades 9 through 11) or only for some of their high school years. ${ }^{30}$

Table VII shows treatment effects by these two proxy measures of income. We find weak evidence that the intervention had a larger effect for more disadvantaged students. Though the estimated effects are statistically indistinguishable, the effects for the more disadvantaged students - those who qualify for a fully free lunch and those who were disadvantaged for all of high school—are consistently larger in magnitude

\footnotetext{
${ }^{30}$ The majority of students in our sample received a free lunch (70 percent) compared to a reduced-price lunch ( 30 percent). 84 percent of students in our sample qualified as economically disadvantaged for every year we observed them, while the remaining 16 percent were disadvantaged for only some of their high school years.
} 
than for their more advantaged peers.

\section{E Mechanisms: Academic Qualifications}

Though all students in our sample were selected based on academic qualifications that gave them a reasonable chance at acceptance to the University of Michigan, there may be heterogeneous effects within this group of high achievers. To test this, we estimate interaction effects between the treatment and SAT score (scaled by 100), controlling for GPA. ${ }^{31}$ Analogously, we interact the treatment with GPA, controlling for SAT score.

Table VIII shows treatment effect heterogeneity by SAT score and GPA. On the application margin, we find a negative relationship between treatment effect and student achievement, with HAIL having a larger effect on the lower achieving students in the sample. Among students scoring one standard deviation (about 90 points) below the average SAT in our sample, the treatment effect is 6 percentage points higher; for those with a GPA one standard deviation ( 0.185 grade points) below the sample average, the treatment effect is about 2 percentage points higher. ${ }^{32}$

In contrast, on the admission and enrollment margin, we find larger treatment effects for the relatively higher-achieving students in the sample. Among students scoring one standard deviation above the the average SAT in our sample, the treatment on enrollment effect is 2.7 percentage points higher; for those with a GPA one standard deviation above the sample average, the treatment effect is 5 percentage points higher.

Together, these results suggest that while the intervention was most successful in inducing relatively lower-achieving students to apply to the University of Michigan, because students with higher test scores and GPAs were more likely to gain admission, the intervention was most successful in inducing higher-achieving students to enroll.

\section{F Mechanisms: Additional Student Characteristics}

We find substantial differences in treatment effects across race and ethnic groups (see Table IX and Appendix Figure VII). This closely tracks the geographic variation, and is in fact difficult to distinguish from it. In Michigan, black and Hispanic students are concentrated in the cities, while the rural areas are largely white. We have insufficient support in our sample to precisely estimate racial effects within region (or regional effects within race).

Given that we found the largest effects outside the urban Southeast, it is unsurprising that our treatment effects are largest among white and Asian students. This is driven by racial differences in behavior within the control group, in which underrepresented minority students (who are concentrated in cities) were much more likely to apply to and attend the university than white students.

\footnotetext{
${ }^{31}$ Due to the nature of the HAIL academic criteria, which allow students with lower test scores to qualify if they have a higher GPA and vice versa, in our sample test score and GPA are negatively correlated. This means that a standard heterogeneity analysis where we interact SAT score (or GPA) with the treatment would be hard to interpret, since the two measures of academic achievement move in opposite directions. We include dummies for GPA [or, when estimating effects by GPA, SAT score] to control for this.

${ }^{32}$ Note that these standard deviations-90 points for SAT and 0.185 for GPA-differ from the standard deviations reported in Table II because the latter are calculated at the school-year level. Though we conduct most analyses at the level of treatment, the school-year level, results by academic achievement are done at the student level.
} 
Table VII

Estimated Effect of HAIL Scholarship on UM Application, Admission, and Enrollment by Economic Status

First and Second HAIL Cohorts

\begin{tabular}{|c|c|c|c|c|}
\hline & \multicolumn{2}{|c|}{$\begin{array}{c}\text { Panel A. Free or Reduced } \\
\text { Price Lunch Eligibility }\end{array}$} & \multicolumn{2}{|c|}{$\begin{array}{l}\text { Panel B. Persistence of } \\
\text { Economic Disadvantage }\end{array}$} \\
\hline & $\begin{array}{l}\text { Free } \\
\text { Lunch }\end{array}$ & $\begin{array}{l}\text { Reduced- } \\
\text { Price }\end{array}$ & $\begin{array}{c}\text { Always } \\
\text { Disadvantaged }\end{array}$ & $\begin{array}{c}\text { Sometimes } \\
\text { Disadvantaged }\end{array}$ \\
\hline Applied & $\begin{array}{c}0.419 \\
(0.023) \\
{[0.27]}\end{array}$ & $\begin{array}{c}0.414 \\
(0.032) \\
{[0.245]}\end{array}$ & $\begin{array}{c}0.423 \\
(0.022) \\
{[0.259]}\end{array}$ & $\begin{array}{c}0.402 \\
(0.041) \\
{[0.302]}\end{array}$ \\
\hline Admitted & $\begin{array}{c}0.170 \\
(0.021) \\
{[0.27]}\end{array}$ & $\begin{array}{c}0.142 \\
(0.029) \\
{[0.146]}\end{array}$ & $\begin{array}{c}0.177 \\
(0.020) \\
{[0.149]}\end{array}$ & $\begin{array}{c}0.152 \\
(0.037) \\
{[0.167]}\end{array}$ \\
\hline Enrolled & $\begin{array}{c}0.146 \\
(0.020) \\
{[0.116]}\end{array}$ & $\begin{array}{c}0.112 \\
(0.026) \\
{[0.118]}\end{array}$ & $\begin{array}{c}0.153 \\
(0.019) \\
{[0.118]}\end{array}$ & $\begin{array}{c}0.140 \\
(0.035) \\
{[0.13]}\end{array}$ \\
\hline $\begin{array}{l}\text { Number of school-years } \\
\text { Number of students }\end{array}$ & $\begin{array}{c}923 \\
2,748\end{array}$ & $\begin{array}{c}607 \\
1,162\end{array}$ & $\begin{array}{c}982 \\
3,268\end{array}$ & $\begin{array}{l}425 \\
642\end{array}$ \\
\hline
\end{tabular}

Source: Michigan administrative data and University of Michigan Office of Enrollment Management data.

Notes: All analyses done at the school-year level. Coefficients are from separate regressions of school-subgroup-level outcome rate on treatment status and strata dummies. A student is always disadvantaged if they are economically disadvantaged for every year they are observed between 9th and 11th grade (including repeated grades). Robust standard errors reported in parentheses. Control mean for subgroup in brackets. UM application, admission and enrollment measured in the summer and fall following expected high school graduation. Admission and enrollment are unconditional on application. In Panel A, eligibility is measured in 11th grade. In Panel B, "always disadvantaged" is defined as being eligible for free or reduced-price lunch every (observed) year of high school through 11th grade. 
Table VIII

Estimated Effect of HAIL Scholarship on UM Application, Admission, and Enrollment by Academic Achievement

First and Second HAIL Cohorts

\begin{tabular}{|c|c|c|c|c|}
\hline \multirow[b]{2}{*}{ Outcome } & \multicolumn{4}{|c|}{ Panel A. Heterogeneity by SAT (controlling for GPA) } \\
\hline & $\begin{array}{c}\text { Treatment } \\
\text { (main effect) }\end{array}$ & $\begin{array}{l}\text { SAT score } / 100 \\
\text { (main effect) }\end{array}$ & $\begin{array}{c}\text { Interaction } \\
(\text { Treat*SAT/100) }\end{array}$ & $\begin{array}{l}\text { Change in } \\
\text { treatment effect } \\
\text { for } 1 \mathrm{sd} \text { increase } \\
\text { in SAT ( } 90 \mathrm{pts})\end{array}$ \\
\hline Applied & $\begin{array}{c}0.371 \\
(0.023)\end{array}$ & $\begin{array}{c}0.150 \\
(0.013)\end{array}$ & $\begin{array}{l}-0.065 \\
(0.016)\end{array}$ & -.059 \\
\hline Admitted & $\begin{array}{c}0.143 \\
(0.018)\end{array}$ & $\begin{array}{c}0.135 \\
(0.012)\end{array}$ & $\begin{array}{c}0.034 \\
(0.017)\end{array}$ & .031 \\
\hline \multirow[t]{3}{*}{ Enrolled } & $\begin{array}{c}0.120 \\
(0.016)\end{array}$ & $\begin{array}{c}0.101 \\
(0.011)\end{array}$ & $\begin{array}{c}0.031 \\
(0.017)\end{array}$ & .027 \\
\hline & \multicolumn{4}{|c|}{ Panel B. Heterogeneity by GPA (controlling for SAT) } \\
\hline & $\begin{array}{c}\text { Treatment } \\
\text { (main effect) }\end{array}$ & $\begin{array}{c}\text { GPA } \\
\text { (main effect) }\end{array}$ & $\begin{array}{c}\text { Interaction } \\
\text { (Treat*GPA) }\end{array}$ & $\begin{array}{c}\text { Change in } \\
\text { treatment effect } \\
\text { for } 1 \mathrm{sd} \text { increase } \\
\text { in GPA }(0.185 \mathrm{pts})\end{array}$ \\
\hline Applied & $\begin{array}{c}0.374 \\
(0.023)\end{array}$ & $\begin{array}{c}0.461 \\
(0.062)\end{array}$ & $\begin{array}{l}-0.095 \\
(0.081)\end{array}$ & -.018 \\
\hline Admitted & $\begin{array}{c}0.145 \\
(0.018)\end{array}$ & $\begin{array}{c}0.569 \\
(0.050)\end{array}$ & $\begin{array}{c}0.328 \\
(0.070)\end{array}$ & .061 \\
\hline Enrolled & $\begin{array}{c}0.122 \\
(0.016)\end{array}$ & $\begin{array}{c}0.472 \\
(0.045)\end{array}$ & $\begin{array}{c}0.270 \\
(0.062)\end{array}$ & .05 \\
\hline Number of students & & & 3,910 & \\
\hline
\end{tabular}

Source: Michigan administrative data and University of Michigan Office of Enrollment Management data.

Notes: Coefficients in Panel A are from student-level regression of the outcome on treatment, SAT score/100, the interaction between the two, strata dummies, and dummies for bin of GPA. SAT score has been centered around its mean and scaled by 100; a one unit increase should be interpreted as 100 points on the SAT. Coefficients in Panel B are from student-level regression of the outcome on treatment, GPA, the interaction between the two, strata dummies, and dummies for bin of SAT score. GPA has been centered around its mean. The standard deviations of SAT and GPA are calculated at the student level. Standard errors are clustered at the school level. Application, admission and enrollment measured in the summer and fall following expected high school graduation. Admission and enrollment are unconditional on application. 
Table IX

Estimated Effect of HAIL Scholarship on UM Application, Admission, and Enrollment by Student Gender and Race

First and Second HAIL Cohorts

\begin{tabular}{|c|c|c|c|c|c|}
\hline & \multicolumn{2}{|c|}{ Panel A. Gender } & \multicolumn{3}{|c|}{ Panel B. Race/Ethnicity } \\
\hline & Male & Female & $\begin{array}{l}\text { White or } \\
\text { Asian }\end{array}$ & Black & Other \\
\hline Applied & $\begin{array}{c}0.406 \\
(0.028) \\
{[0.286]}\end{array}$ & $\begin{array}{c}0.422 \\
(0.024) \\
{[0.239]}\end{array}$ & $\begin{array}{c}0.438 \\
(0.022) \\
{[0.234]}\end{array}$ & $\begin{array}{c}0.262 \\
(0.060) \\
{[0.478]}\end{array}$ & $\begin{array}{r}0.242 \\
(0.068) \\
{[0.393]}\end{array}$ \\
\hline Admitted & $\begin{array}{c}0.141 \\
(0.024) \\
{[0.139]}\end{array}$ & $\begin{array}{c}0.188 \\
(0.022) \\
{[0.143]}\end{array}$ & $\begin{array}{c}0.182 \\
(0.019) \\
{[0.129]}\end{array}$ & $\begin{array}{c}0.072 \\
(0.059) \\
{[0.283]}\end{array}$ & $\begin{array}{r}0.043 \\
(0.062) \\
{[0.258]}\end{array}$ \\
\hline Enrolled & $\begin{array}{c}0.118 \\
(0.022) \\
{[0.105]}\end{array}$ & $\begin{array}{c}0.164 \\
(0.021) \\
{[0.115]}\end{array}$ & $\begin{array}{c}0.154 \\
(0.018) \\
{[0.103]}\end{array}$ & $\begin{array}{c}0.037 \\
(0.055) \\
{[0.234]}\end{array}$ & $\begin{array}{r}0.072 \\
(0.058) \\
{[0.199]}\end{array}$ \\
\hline $\begin{array}{l}\text { Number of school-years } \\
\text { Number of students }\end{array}$ & $\begin{array}{c}729 \\
1,637\end{array}$ & $\begin{array}{c}855 \\
2,273\end{array}$ & $\begin{array}{c}948 \\
3,312\end{array}$ & $\begin{array}{l}206 \\
330\end{array}$ & $\begin{array}{l}191 \\
268\end{array}$ \\
\hline
\end{tabular}

Source: Michigan administrative data and University of Michigan Office of Enrollment Management data.

Notes: All analyses done at the school-year level. Coefficients are from separate regressions of school-subgroup-level outcome rate on treatment status and strata dummies. Robust standard errors reported in parentheses. Control mean for subgroup in brackets. UM application, admission and enrollment measured in the summer and fall following expected high school graduation. Admission and enrollment are unconditional on application. 
Nearly half of black students in the control group applied to University of Michigan (48 percent), compared to only 23 percent of white and Asian students. About a quarter of black students enrolled (23 percent), compared to ten percent of whites and Asians. The intervention reduced these differences by equalizing treatment outcomes across racial groups: treatment effects on enrollment are largest for whites and Asians (15 percentage points) and smaller (and imprecise) for other minority students (7 percentage points) and black students (4 percentage points).

Finally, we examine differences by gender. Men are known to be more confident in their skills than women and are more likely to prefer competitive environments (Niederle and Vesterlund 2007). In the control group, women were five percentage points less likely to apply than men ( 24 vs. 29 percent) but slightly more likely to enroll (12 vs. 11 percent), suggesting that, absent the treatment, female applicants are more qualified than male applicants. The HAIL treatment narrowed the gender gap in application from five percentage points to three (66 percent of women and 69 percent of men applied to University of Michigan from the treatment group) and widened the female advantage in enrollment from one percentage point to six. These results are consistent with HAIL compensating for women's lower levels of confidence about applying to a highly selective school.

\section{G Summary of Mechanisms}

All of the above results point to a consistent finding: the HAIL intervention was most successful at changing application behavior for the students who were least likely to apply, whether because of geographic distance from the university, a lack of peers considering selective schools, or academic achievement. On the other hand, the intervention was most successful in enrolling students who were previously disconnected from the university but academically competitive enough to get in.

To summarize these effects, we create a single index that captures how likely a student would be, in the absence of the intervention, to attend a highly selective school, generated by estimating a regression predicting attendance at a highly competitive (or above) college. ${ }^{33}$ We estimate this regression for cohorts of low-income, high-achieving students in the two years prior to HAIL. We apply the estimated coefficients to our analysis sample to obtain predicted probabilities of selective college-going. ${ }^{34}$

Figure VI shows how this index predicts observed application, admission, and enrollment, and how the intervention changed the relationship. We display scatterplots with 20 equally sized bins of students, where the $x$-value is the within-bin mean of the index. A quadratic line is fitted through the binned points. For each of the three main outcomes, we show scatterplots by treatment status as well as a version that shows treatment effects (the within-bin treatment - control difference).

Focusing first on the application decision (panels (a) and (b)), there is a strong positive relationship between the index and the likelihood of applying to the University of Michigan. The HAIL intervention weakened this relationship, most affecting the applications of students who were, at baseline, least likely to

\footnotetext{
${ }^{33}$ Based on race, gender, ACT, GPA, urbanicity and region of high school, number of low-income, high-achieving students in the school, historical school rate of UM attendance, and persistence of economic disadvantage. Attendance at a highly selective school measured using data from the National Student Clearinghouse.

${ }^{34}$ The estimated coefficients from this exercise are shown in Appendix Table XII.
} 
attend a selective school.

For admission and enrollment, the picture tells a different story. As with application, the control students with the highest predicted probabilities of selective attendance are most likely to be admitted and enroll at the University of Michigan (this is true almost by construction). In contrast to the application outcome, the treatment effects on admission and enrollment are larger for students who were more likely to attend in the first place (though the treatment had a positive effect at every point on the distribution).

\section{Welfare EFFects And Unintended ConseQuenCES}

The results discussed thus far illustrate HAIL's effect on sample students' application and enrollment at the University of Michigan. But the welfare implications are unclear. The intervention could have reduced enrollment in other highly selective schools, for example.

In this next section, we examine the implications of these behavioral responses for student and social welfare. We test whether HAIL increased the share of low-income, high-achieving students attending highly selective colleges, whether students induced to enroll persisted in college, how their financial aid packages compared to other low-income students, and whether HAIL had any spillover effects on students attending HAIL-treated schools.

\section{A Did the Intervention Poach Students from Other Selective Colleges?}

It is possible that the intervention simply diverted students from schools as selective as UM (e.g., Berkeley, Harvard), which would produce little change in (or even harm) the long-term welfare of the affected students. It is also possible that the packet encouraged students to apply to selective schools other than University of Michigan. We turn to data from the National Student Clearinghouse to examine enrollment nationwide (we do not have application or admissions data for schools other than the University of Michigan).

We find no diversion from colleges at least as selective as the University of Michigan (Table $\mathrm{X}$ and Appendix Figure VIII). The offer of the HAIL scholarship increased enrollment at a highly (or most) selective college by 14.6 percentage points. This is identical to the effect on attendance at University of Michigan, which implies that on net, HAIL neither discouraged, nor encouraged students from enrolling at other highly-selective institutions. ${ }^{35}$

Students in the treatment group were 3.9 percentage points more likely to attend any post-secondary institution than those in the control group. That is, roughly one quarter of the increase in enrollment at the University of Michigan is driven by students who would not have attended any college in the absence of the treatment. We did not anticipate this result; it seemed unlikely that students this well prepared would be on the margin of not attending college.

Additionally, the offer of HAIL increased the share of students enrolling at any four-year college (7.4 percentage points) and decreased the share enrolling at two-year colleges (3.5 percentage points). Together,

\footnotetext{
${ }^{35}$ This estimate (which uses National Student Clearinghouse data) and the previously discussed estimate (based on University of Michigan data, Table III) are nearly identical: 14.6 versus 14.9 percentage points. The minor difference is attributable to differences in the dates on which NSC and University of Michigan record enrollment.
} 


\section{Figure VI}

Estimated Effect of HAIL Scholarship by Predicted Probability of Selective College Attendance First and Second HAIL Cohorts

(a) Application by Predicted Probability of Selective College Attendance and Treatment Status

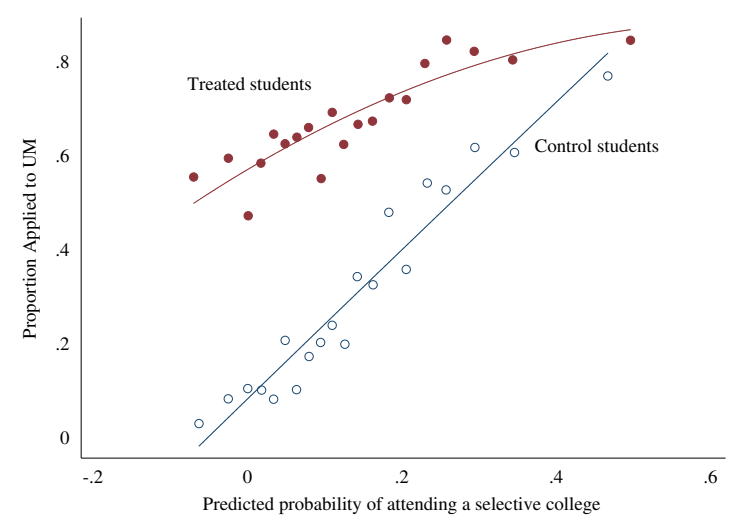

(c) Admission by Predicted Probability of Selective College Attendance and Treatment Status

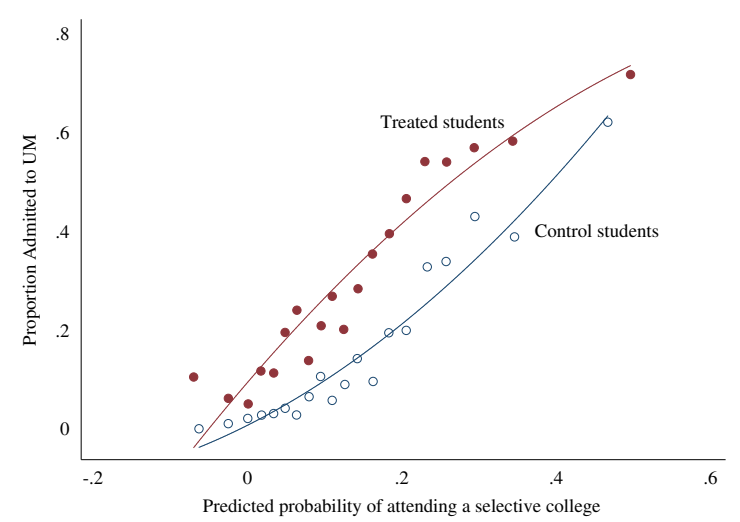

(b) Application Treatment Effect by Predicted Probability of Selective College Attendance

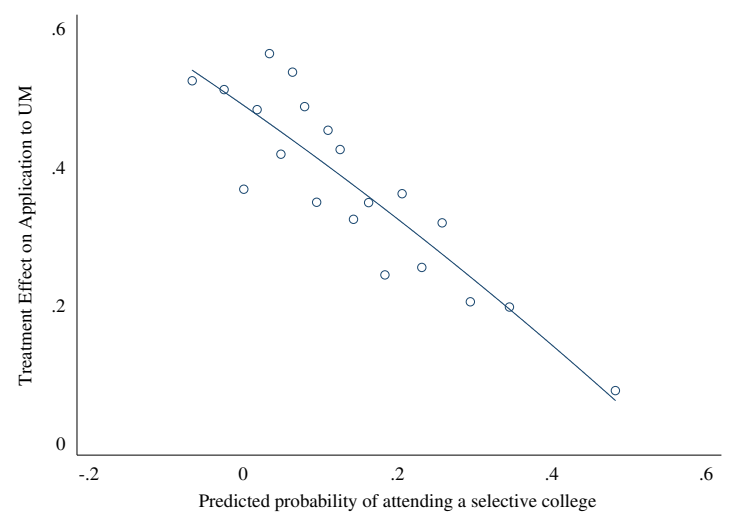

(d) Admission Treatment Effect by Predicted Probability of Selective College Attendance

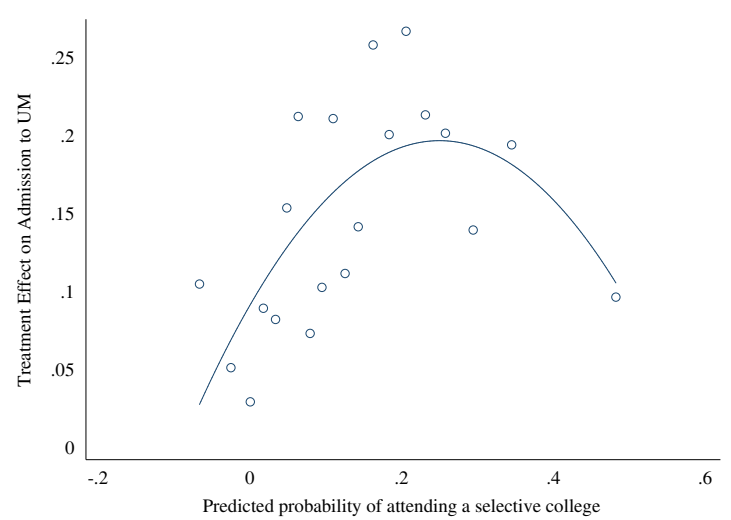

(e) Enrollment by Predicted Probability of Selective College (f) Enrollment Treatment Effect by Predicted Probability of Attendance and Treatment Status Selective College Attendance
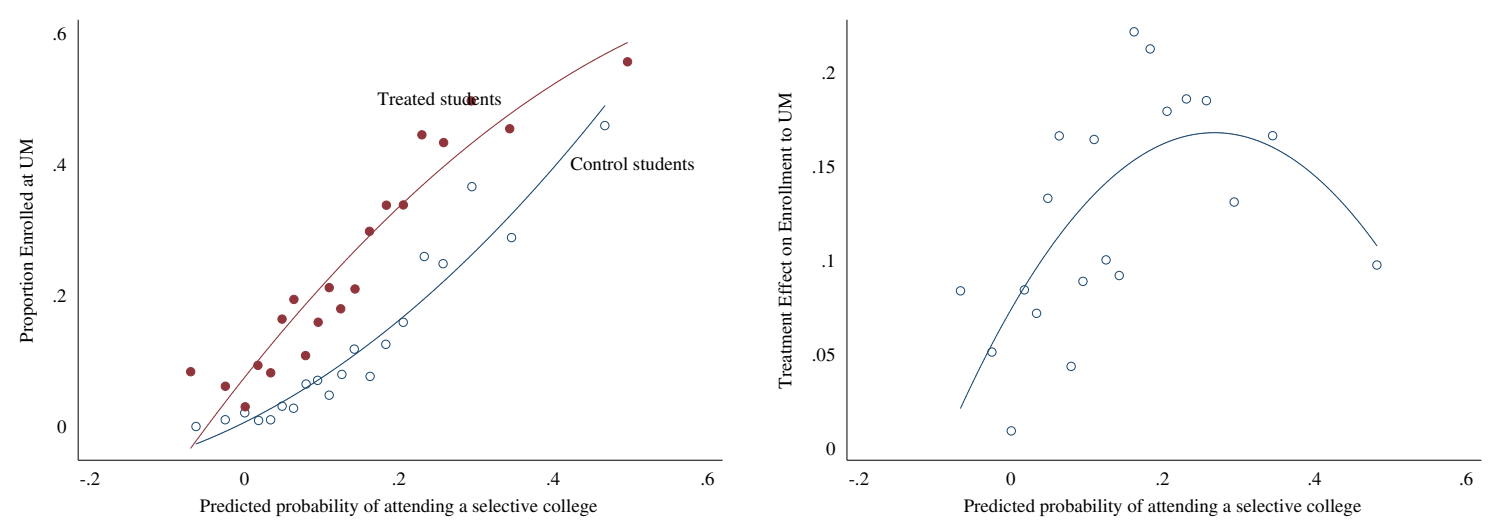

Source: Michigan administrative data and University of Michigan Office of Enrollment Management data.

Notes: This analysis is done at the student level. Selective college attendance is predicted based on a regression of attending a highly competitive or above school on race, gender, ACT, GPA, urbanicity and region of high school, number of eligible students in school, historical school rate of UM attendance, and persistence of economic disadvantage, estimated on the two cohorts prior to HAIL. Application, admission and enrollment measured in the summer and fall following expected high school graduation. Admission and enrollment are unconditional on application. 
Table X

Estimated Effect of HAIL Scholarship on College Choice First and Second HAIL Cohorts

\begin{tabular}{|c|c|c|}
\hline College attended & Treatment effect & Control mean \\
\hline Highly competitive or above & $\begin{array}{c}0.146 \\
(0.018)\end{array}$ & 0.135 \\
\hline UM & $\begin{array}{c}0.146 \\
(0.016)\end{array}$ & 0.107 \\
\hline $\begin{array}{l}\text { Highly competitive or above } \\
\text { other than UM }\end{array}$ & $\begin{array}{c}0.000 \\
(0.007)\end{array}$ & 0.028 \\
\hline Four-year & $\begin{array}{c}0.074 \\
(0.020)\end{array}$ & 0.675 \\
\hline Two-year & $\begin{array}{l}-0.035 \\
(0.013)\end{array}$ & 0.116 \\
\hline Any & $\begin{array}{c}0.039 \\
(0.018)\end{array}$ & 0.791 \\
\hline In Michigan & $\begin{array}{c}0.045 \\
(0.020)\end{array}$ & 0.727 \\
\hline Public in Michigan & $\begin{array}{c}0.062 \\
(0.021)\end{array}$ & 0.645 \\
\hline Outside Michigan & $\begin{array}{l}-0.006 \\
(0.010)\end{array}$ & 0.064 \\
\hline $\begin{array}{l}\text { Number of school-years } \\
\text { Number of students }\end{array}$ & \multicolumn{2}{|c|}{1,026} \\
\hline
\end{tabular}

Source: Michigan administrative data and National Student Clearinghouse data.

Notes: All analyses done at the school-year level. Coefficients are from regressions of outcome on treatment status and strata dummies. Robust standard errors reported. Enrollment is measured at the first college attended in the fall following expected high school graduation and is unconditional on any college enrollment. 
these results show that nearly half of HAIL's effect on enrollment is diversion from two-year colleges and non-attendance. The other half of the enrollment effect is drawn from four-year colleges that are less selective than the University of Michigan. ${ }^{36}$

These results are consistent with responses from focus groups held among students from the treatment group who enrolled at the University of Michigan. Of the 15 students interviewed in the focus groups, 12 had no intention of applying to the University of Michigan before the intervention. Typical among the target institutions mentioned by students were regional, four-year institutions such as Grand Valley State, Ferris State, Central Michigan University, Wayne State University, and Eastern Michigan University. One student in the focus group had contemplated a two-year college, while another explained that they "didn't count on going to college at all until I got the packet" (Glasener et al. 2018, and unpublished focus group transcripts).

\section{B Did Students Induced to Attend Quickly Drop Out?}

Did those induced by HAIL into a highly selective college persist in college, or quickly drop out? Before undermatch was a hot topic, overmatch was a key concern, with some worried that disadvantaged students induced to attend highly selective schools would not be able to handle the academic competition. But recent research suggests that students are more likely to graduate if they attend the best school they can get into (Hoekstra 2009; Zimmerman 2014; Dillon and Smith 2018). While we cannot yet observe graduation, we do have data on attendance in two consecutive years for the first cohort of students, which allows us to examine persistence in college. We find that the HAIL effects persist into the second year (Table XI). Students offered the HAIL Scholarship are 13.5 percentage points more likely than controls to be enrolled in a highly (or most) selective college for two years. That is, the two-year effect on attending such a selective college is 88 percent $(=13.5 / 15.3)$ of the one-year effect.

On all other measures, we find larger treatment effects over a two-year horizon than over one year. Students offered HAIL are 11 percentage points more likely to be enrolled in a four-year college for two years (the one-year effect is 9.1 percentage points), and they are eight percentage points more likely than controls to enroll in any college for two consecutive years. This is partly driven by HAIL getting students into college in the first place (the increase of four percentage points seen in Table X) and partly by inframarginal college students attending a more selective college with a higher retention rate. ${ }^{37}$ This is consistent with the hypothesis that students induced into more selective schools, with their better-prepared peers and more resources, are more likely to remain in school and graduate.

\footnotetext{
${ }^{36}$ Appendix Table XIV presents subgroup results by region, urbanicity, race, and gender. Consistent with results discussed thus far, we found largest college enrollment effects among students in the more rural areas of the state, substantially narrowing urban/rural gaps in college choices. Effects were slightly larger for women compared to men, particularly on the any-college margin. Results by race were more nuanced: in the absence of the treatment, white and Asian treated students would have attended less selective four-year institutions, while treated students from other minority groups would not have gone to college at all or would have attended two-year institutions. We found no statistically significant effects on college choice for black students, though point estimates are noisy.

${ }^{37}$ Persistence effects are largest in suburban and rural areas of the state, and for female students (see Appendix Table XVI). Persistence effects by race/ethnicity are consistent with the initial enrollment results: we find larger effects among white and Asian students, while effects for other racial minorities are noisy and often not significant. Control group means were also higher among these other minorities, which again points to the treatment having the largest impact on students who were otherwise less likely to attend a highly selective school.
} 


\section{Was the Intervention Costly?}

The cost of printing and mailing the intervention packages was low, approximately $\$ 10$ per student. Beyond the cost of the packet, did the promise of free tuition cost the university more in financial aid than they would otherwise provide low-income students? In analyzing prior cohorts of low-income students enrolled at the University of Michigan, we found that 90 percent of students received at least a full-tuition scholarship. This implies that, for the vast majority of students in our sample, the HAIL scholarship offer informs students about financial aid for which they were already eligible.

Table XI

Estimated Effect of HAIL Scholarship on College Enrollment and Persistence First HAIL Cohort

\begin{tabular}{|c|c|c|c|c|}
\hline \multirow[b]{2}{*}{ College attended } & \multicolumn{2}{|c|}{$\begin{array}{l}\text { Attended fall following high school } \\
\text { graduation }\end{array}$} & \multicolumn{2}{|c|}{$\begin{array}{l}\text { Attended two consecutive falls } \\
\text { following high school graduation }\end{array}$} \\
\hline & Treatment effect & Control mean & Treatment effect & Control mean \\
\hline Highly competitive or above & $\begin{array}{c}0.153 \\
(0.024)\end{array}$ & 0.129 & $\begin{array}{c}0.135 \\
(0.023)\end{array}$ & 0.126 \\
\hline UM & $\begin{array}{c}0.147 \\
(0.022)\end{array}$ & 0.104 & $\begin{array}{c}0.128 \\
(0.022)\end{array}$ & 0.102 \\
\hline Four-year & $\begin{array}{c}0.091 \\
(0.028)\end{array}$ & 0.651 & $\begin{array}{c}0.109 \\
(0.029)\end{array}$ & 0.557 \\
\hline Any & $\begin{array}{c}0.057 \\
(0.025)\end{array}$ & 0.779 & $\begin{array}{c}0.079 \\
(0.027)\end{array}$ & 0.683 \\
\hline $\begin{array}{l}\text { Number of school-years } \\
\text { Number of students }\end{array}$ & & & & \\
\hline
\end{tabular}

Source: Michigan administrative data and National Student Clearinghouse data.

Notes: All analyses done at the school-year level. Coefficients are from regressions of outcome on treatment status and strata dummies. Robust standard errors reported. Enrollment is measured at the first college attended in the two falls following expected high school graduation and is unconditional on any college enrollment.

Not surprisingly then, we find no significant differences in the financial aid packages of students in the treatment and control groups who enrolled at the University of Michigan (see Table XII). Since HAIL induced students to enroll, we do not interpret these results in any causal way, but provide this information to illustrate that HAIL students were treated identically (in terms of their financial aid packages) as other low-income students enrolled at the University of Michigan.

Students from the treatment and control groups came from families with similar incomes $(\$ 36,000)$, and similar expected family contributions (just over $\$ 3,000$ ). Treated students had slightly higher earnings than those in the control group, of about $\$ 300$ in their first year of college, but financial aid packages were nearly identical. Both treatment and control students received, on average, around $\$ 24,000$ in grants and scholarships in their first year, and the vast majority of that came from university grants. Approximately 85 
percent of students received Pell grants, and the average amount was over $\$ 4,000$. Treated students were slightly more likely to receive work study, generating differences in their average work study amounts. These comparisons are quite similar in the first and second year of enrollment. Overall, Table XII suggests that HAIL does not cost the university more in terms of financial aid than they would otherwise provide low-income students. 
Table XII

Financial Aid for HAIL Treatment and Control Students Enrolled at UM, by Year of College Enrollment (Non-experimental Results) First and Second HAIL Cohorts

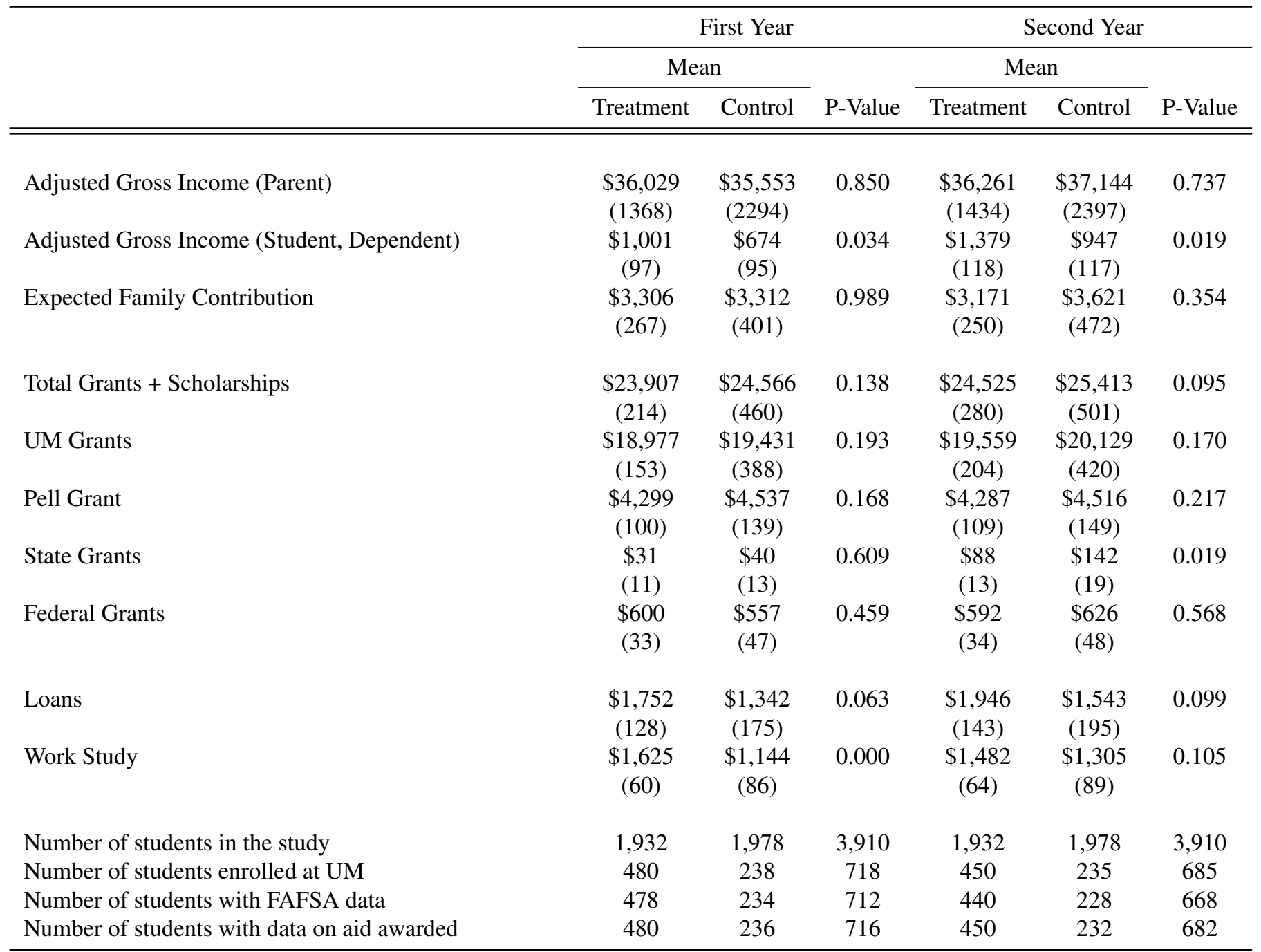

Source: Michigan administrative data and University of Michigan Office of Enrollment Management data.

Notes: Analyses done at the student level, for students enrolled at UM and with financial aid information available. First Year refers to the first year of college enrollment, i.e., the academic year following high school graduation. 


\section{Did the Intervention Discourage Any Students?}

There are at least two ways in which the intervention could have harmed some students. Students in the treatment group who applied but were rejected from the University of Michigan may have been discouraged from applying to or attending other colleges. A second channel is that HAIL may have affected students outside of the study population. The University of Michigan is a highly-selective college: If a HAIL student gains admission, it means that another student does not. By implication, there would be spillover effects on students outside of the study population. For instance, peers attending HAIL-treated schools who saw their classmates receive these offers but did not receive them themselves may have been discouraged from applying to the University of Michigan. Additionally, if the university uses informal quotas for each high school, an additional HAIL student gaining admission could crowd out other applicants from the same high school.

For the first type of student- those from the treatment group who applied but were rejected - the key question is whether they would have been better off if they had not applied at all than to have applied and been rejected. One scenario is that students are so encouraged by the mailings that they focus all of their application efforts on University of Michigan, to the exclusion of other colleges. This would tend to reduce the rate of college attendance in the treatment group, relative to the control group.

While we cannot use the experimental design to address this question directly since we do not have random variation in admission among applicants, we find that the treatment increased the likelihood of attending any college by four percentage points and the likelihood of attending a four-year college by seven percentage points (see Table X). If there were any discouragement effects they were more than offset by the encouragement effects of the intervention.

The HAIL intervention may have also affected the college choices of high school classmates who were ineligible for the HAIL scholarship (those who failed to meet the income or academic criteria). The sign of any spillover effect is theoretically ambiguous. Seeing a peer offered the HAIL Scholarship may suggest to a student that she is not University of Michigan material, decreasing the likelihood of application. On the other hand, seeing a peer offered the HAIL scholarship may make the University of Michigan seem more accessible to students (or adults around them), thereby increasing the likelihood of application. Finally, the University of Michigan may have informal quotas for each school, which would mechanically constrain admissions for classmates.

To check for spillover effects, we replicate our analysis among students not eligible for HAIL, with the treatment dummy indicating that their school is in the HAIL treatment group. We find no evidence of negative (or positive) spillover effects on students attending HAIL-treated schools who did not receive the offer. $^{38}$ Despite dramatically increasing enrollment of low-income, high-achieving students, this result is not entirely surprising, since HAIL students make up a small fraction of the total freshman class size. Each year, HAIL induced approximately 150 additional students to enroll, while the freshman class at the University of

\footnotetext{
${ }^{38}$ See Appendix Table XVII. In unconditional regression models, we find that the application rate is 1.1 percentage points lower for non-HAIL students at treatment schools than at control schools. But, after we control for baseline application rates, this negative spillover effect disappears. Recall (see Table II) that the treatment and control schools were slightly imbalanced on this baseline attribute. Among cohorts graduating prior to the HAIL scholarship intervention, students from treated schools were 1.2 percentage points less likely to apply to the University of Michigan than students from control schools.
} 
Michigan is over 6,000 students. ${ }^{39}$

\section{CONCLUSION}

We close the paper with the statistics that motivated it: gaps in college choice between low-income students and their higher-income peers in Michigan (Figure VII). HAIL closed by half the income gap in college attendance among high-achieving students: the college attendance rate is 88 percent among upper-income students, 85 percent among low-income students in the treatment group, and 81 percent among low-income students in the control group.

HAIL also narrowed, eliminated, and even reversed income gaps in college selectivity. The intervention shifted students away from two-year and less selective four-year colleges (Table X and Appendix Figure VIII). The gap in attending an institution considered "selective" or above was reduced from 12 percentage points to 4 percentage points, and the income gap in attending an institution considered "very selective" or above was eliminated. Low-income, high-achieving students offered HAIL are more likely to attend a university at least as selective as University of Michigan than their higher-income peers: 26 vs. 20 percent, respectively. We find no evidence that HAIL diverted students from other highly selective institutions. Finally, these effects have lasted: students offered the HAIL Scholarship have persisted in college at substantially higher rates than students in the control group.

These results indicate that a low-cost, low-touch intervention can strongly affect student application and enrollment at selective colleges. This contrasts with the conclusion of Carrell and Sacerdote (2017) that only high-touch, "boots on the ground" interventions can have large effects on students' decisions to apply to and attend college.

The behavioral patterns uncovered by this study have broad implications for policy. People frequently make consequential decisions in complex, uncertain environments. Our study adds to a body of evidence showing that the design of those environments can profoundly shape the decisions made (Madrian and Shea 2001; Pallais 2015; Herd and Moynihan 2018; Marx and Turner 2019).

This is true whether the design is intentional or the product of a series of uncoordinated decisions. Like many means-tested programs, the student aid system in the US is rife with detailed rules and extensive paperwork. Many of these rules are the accidental product of well-intentioned actors. A legislator may, for example, sponsor a provision to extend additional aid to homeless students. Depending on how this is implemented, this could further add to program complexity. In 2007, Congress passed legislation guaranteeing aid eligibility to homeless students. The Department of Education implemented this directive by adding three lengthy, legalistic questions to the FAFSA that probe for homeless status.

The broadest conclusion to be drawn is that the "last mile" of policy implementation can have serious distributional consequences. The design of a user interface, the length of a form, and the timing of information delivery can have profound effects on behavior. Research suggests that this is especially true for poor people

\footnotetext{
${ }^{39}$ In the first year of the intervention, the University of Michigan grew its class size, meaning that the increase in low-income students enrolling because of HAIL would not necessarily displace other students. In the second year, while no such class size adjustments were intentionally made, the entering freshman class was also substantially larger than in previous years.
} 


\section{Figure VII}

Selectivity of Colleges Attended by High-Achieving Michigan Students, by Income and HAIL Treatment Status

First and Second HAIL Cohorts

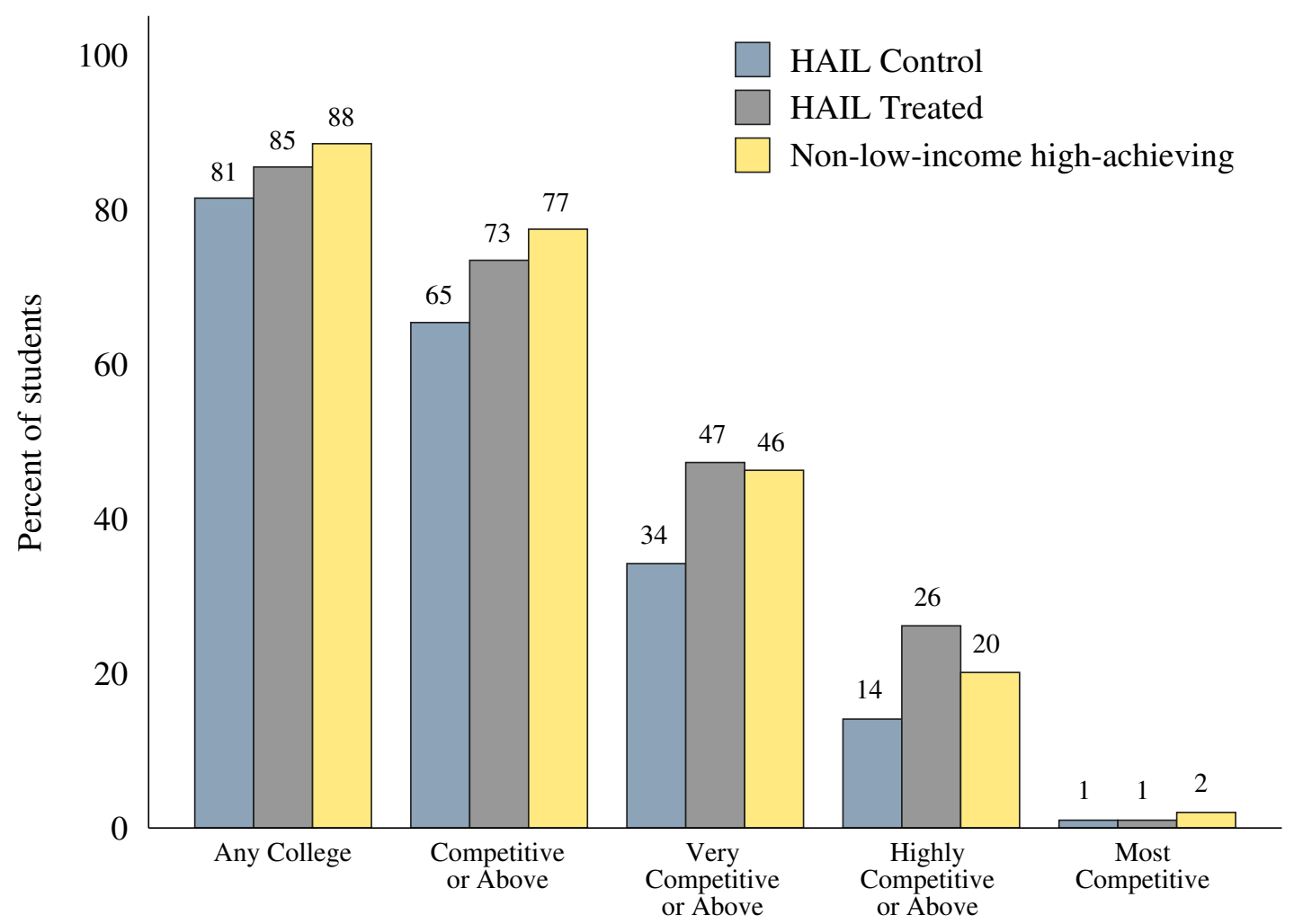

Source: Michigan administrative data and National Student Clearinghouse data.

Notes: Sample is 11th grade students in Michigan public schools in 2015 and 2016 who meet HAIL GPA and ACT/SAT criteria. College enrollment measured at first institution attended in fall following expected high school graduation. Low-income means eligible for free or reduced-price lunch in 11th grade. Selectivity categories from Barron's selectivity index.

(Mullainathan and Shafir 2013). But even among white-collar professionals, details of program administration can affect decisions as consequential as whether to save for retirement. Making employee participation in a company 401(k) opt-out rather than opt-in dramatically increases savings rates (Madrian and Shea 2001).

Most narrowly, our results inform the current discussion about "free college," a policy that is widely discussed in state legislatures, in presidential campaigns, and on Capitol Hill. Our findings suggest that the implementation details will be central to the success of these tuition policies. Critics have noted that some of these programs do nothing to reduce college costs for low-income students, who are already eligible for need-based aid that can fully cover the cost of tuition. They therefore, the argument goes, primarily benefit middle- and upper-income students who do not get need-based aid.

Ex ante, a critic could have precisely made the same critique of our intervention, which did not change the price of college for low-income students. These students were already eligible for the scholarships we offered them. Yet, as we found in our experiment, the details of how "free tuition" is presented will substantially shape its impact. Free-college programs can be designed with required aid forms and back-loaded 
information about eligibility, which is what our control students experienced. Alternatively, they can offer an early, broad guarantee, which is what our treatment students were given.

Our findings suggest that a system that is based on high tuition and high aid for low-income students may not be as effective as a free-tuition regime if the former requires time and effort to learn the net cost of attendance. A free-tuition regime may be worth the loss of targeting if it helps reduce inequality in educational decisions.

\section{REFERENCES}

Ainslie, George. 1975. "Specious reward: a behavioral theory of impulsiveness and impulse control." Psychological bulletin, 82(4): 463.

Andrews, Rodney J, Scott A Imberman, and Michael F Lovenheim. 2016. "Recruiting and supporting low-income, high-achieving students at flagship universities.” NBER Working Paper No. 22260, National Bureau of Economic Research, Cambridge, MA.

Athey, Susan, and Guido W Imbens. 2017. “The Econometrics of Randomized Experiments.” In Handbook of Economic Field Experiments. Vol. 1, 73-140. Elsevier.

Avery, Christopher, and Caroline Hoxby. 2003. "Do and should financial aid packages affect students' college choices?" NBER Working Paper No. 9482, National Bureau of Economic Research, Cambridge, MA.

Avery, Christopher, and Thomas J Kane. 2004. "Student perceptions of college opportunities: The Boston COACH program." In College choices: The economics of where to go, when to go, and how to pay for it. University of Chicago Press Chicago.

Bailey, Martha, and Susan M Dynarski. 2011. "Inequality in postsecondary attainment." In Whither Opportunity. Russell Sage New York.

Baum, Sandy, and Saul Schwartz. 2015. "Student aid, student behavior, and educational attainment." In Decision making for student success: Behavioral insights to improve college access and persistence. Routledge New York.

Benjamin, Daniel, James Choi, and Joshua Strickland. 2010. "Social identity and preferences." American Economic Review, 100(4): 1913-28.

Bergman, Peter, Jeffrey T. Denning, and Dayanand Manoli. 2019. "Is information enough? The effect of information about education tax benefits on student outcomes." Journal of Policy Analysis and Management, 0(0): 1-26.

Bergman, Peter, Jeffrey T Denning, and Day Manoli. 2017. "Broken tax breaks? Evidence from a tax credit information experiment with 1,000,000 students." Working paper.

Beshears, J, James Choi, David Laibson, and B Madrian. 2013. "Simplification and saving." Journal of Economic Behavior and Organization, 95(1): 130-145.

Bettinger, Eric, and Robert Slonim. 2007. "Patience among children." Journal of Public Economics, 91(1-2): 343-363.

Bettinger, Eric P, Bridget Terry Long, Philip Oreopoulos, and Lisa Sanbonmatsu. 2012. "The role of application assistance and information in college decisions: Results from the H\&R Block FAFSA experiment." The Quarterly Journal of Economics, 127(3): 1205-1242.

Black, Dan A, and Jeffrey A Smith. 2006. "Estimating the returns to college quality with multiple proxies for quality." Journal of labor Economics, 24(3): 701-728.

Bowen, William G, Matthew M Chingos, and Michael S McPherson. 2009. Crossing the finish line: Completing college at America's public universities. Princeton University Press.

Bulman, George. 2015. "The effect of access to college assessments on enrollment and attainment." American Economic Journal: Applied Economics, 7(4): 1-36.

Caetano, Gegorio, Miguel Palacios, and Harry Patrinos. 2019. "Measuring aversion to debt: An experiment among student loan candidates." Journal of Family and Economic Issues, 40(1): 117-131.

Calender, C, and J Jackson. 2005. "Does the fear of debt deter students from higher education?" Journal of Social Policy, 34(4): 509-540.

Carrell, Scott, and Bruce Sacerdote. 2017. "Why do college-going interventions work?" American Economic Journal: Applied Economics, 9(3): 124-51. 
Castleman, Benjamin L, and Lindsay C Page. 2016. "Freshman year financial aid nudges: An experiment to increase FAFSA renewal and college persistence." Journal of Human Resources, 51(2): 389-415.

Chapman, Sandra B, Jacquelyn F Gamino, and Raksha Anand Mudar. 2012. "Higher order strategic gist reasoning in adolescence." In The adolescent brain: Learning, reasoning, and decision making. , ed. Valerie F Reyna, Sandra B Chapman, Michael R Dougherty and Jere Confrey, 123-151. American Psychological Association.

Chetty, Raj, John N Friedman, Emmanuel Saez, Nicholas Turner, and Danny Yagan. 2017. "Mobility report cards: The role of colleges in intergenerational mobility.” NBER Working Paper No. 23618, National Bureau of Economic Research, Cambridge, MA.

Cohodes, Sarah R, and Joshua S Goodman. 2014. "Merit aid, college quality, and college completion: Massachusetts' Adams scholarship as an in-kind subsidy." American Economic Journal: Applied Economics, 6(4): 251-85.

Damgaard, Mette, and Helena Nielsen. 2018. "Nudging in education." Economics of Education Review, 64(1): 313-342.

Dillon, Eleanor Wiske, and Jeffrey Andrew Smith. 2017. "Determinants of the match between student ability and college quality." Journal of Labor Economics, 35(1): 45-66.

Dillon, Eleanor Wiske, and Jeffrey A Smith. 2018. "The consequences of academic match between students and colleges.” NBER Working Paper No. 25069, National Bureau of Economic Research, Cambridge, MA.

Dynarski, Susan M, and Judith Scott-Clayton. 2006. "Cost of complexity in federal student aid: Lessons from optimal tax theory and behavioral economics.” National Tax Journal, 59(2): 319-356.

Fernandes, Daniel, John G Lynch Jr, and Richard G Netemeyer. 2014. "Financial literacy, financial education, and downstream financial behaviors." Management Science, 60(8): 1861-1883.

Field, Erica. 2009. "Educational debt burden and career choice: Evidence from a financial aid experiment at NYU law school.” American Economic Journal: Applied Economics, 1(1): 1-21.

Fischer, Mira, and Valentin Wagner. 2018. "Effects of timing and reference frame of feedback: Evidence from a field experiment.” IZA Discussion Paper.

Frederick, Shane, George Loewenstein, and Ted O'Donoghue. 2002. "Time discounting and time preference: A critical review." Journal of economic literature, 40(2): 351-401.

French, Robert, and Philip Oreopoulos. 2017. "Behavioral barriers transitioning to college." Labour Economics, 47(1): 48-63.

Galván, Adriana. 2012. "Risky behavior in adolescents: The role of the developing brain.” In The adolescent brain: Learning, reasoning, and decision making., ed. Valerie F Reyna, Sandra B Chapman, Michael R Dougherty and Jere Confrey, 267-289. American Psychological Association.

Glasener, Kristen, Kelly Slay, Steven Lonn, and Kedra Ishop. 2018. "Beyond Access: Examining Low-Income Students' Academic and Social Transition to a Highly Selective Public University.” Working Paper, Univeristy of Michigan, Ann Arbor, MI.

Goldrick-Rab, Sara, Robert Kelchen, Douglas N Harris, and James Benson. 2016. "Reducing income inequality in educational attainment: Experimental evidence on the impact of financial aid on college completion." American Journal of Sociology, 121(6): 1762-1817.

Goodman, Joshua. 2016. "Learning from the test: Raising selective college enrollment by providing information.” Review of Economics of Statistics, 98(4): 671-684.

Gurantz, Oded, Jessica Howell, Michael Hurwitz, Cassandra Larson, Matea Pender, and Brooke White. 2019. "Realizing Your College Potential? Impacts of College Board's RYCP Campaign on Postsecondary Enrollment." EdWorkingPaper No.19-40, Annenberg Institute at Brown Univeristy, Providence, RI.

Herd, Pamela, and Donald Moynihan. 2018. Administrative burden: Policymaking by other means. Russell Sage Foundation.

Hoekstra, Mark. 2009. "The effect of attending the flagship state university on earnings: A discontinuity-based approach." The Review of Economics and Statistics, 91(4): 717-724.

Hoxby, Caroline, and Sarah Turner. 2013. "Expanding college opportunities for high-achieving, low income students.” Stanford Institute for Economic Policy Research Discussion Paper No. 12-014, Stanford, CA.

Hoxby, Caroline M, and Christopher Avery. 2012. "The missing "one-offs": The hidden supply of high-achieving, low income students.” NBER Working Paper No. 18586, National Bureau of Economic Research, Cambridge, MA. 
Hyman, Joshua. 2019. “Can Light-Touch College-Going Interventions Make a Difference? Evidence From a Statewide Experiment in Michigan.” Forthcoming, Journal of Policy Analysis and Management.

Jabbar, Huriya. 2011. "The behavioral economics of education: New directions for research." Educational Researcher, 40(9): 446-453.

Jensen, Robert. 2010. "The (perceived) returns to education and the demand for schooling." Quarterly Journal of Economics, 125(2): 515-548.

Johnson, Eric, and Daniel Goldstein. 2009. "Do defaults save lives?” Science, 302(1): 1338-1339.

Kahneman, Daniel. 2003. "Maps of bounded rationality: Psychology for behavioral economics." American economic review, 93(5): 1449-1475.

Kahneman, Daniel, and Amos Tversky. 1979. "Prospect theory: An analysis of decision under risk." Econometrica, 47(2): 263-291.

Koch, Alexander, Julia Nafziger, and Helena Nielsen. 2015. "Behavioral economics of education.” Journal of Economic Behavior and Organization, 115(1): 3-17.

Laibson, David. 1997. "Golden eggs and hyperbolic discounting." The Quarterly Journal of Economics, 112(2): 443-478.

Lavecchia, Adam, Heidi Liu, and Philip Oreopoulos. 2016. "Behavioral economics of education: Progress and possibilities." In Handbook of Economics of Education. Vol. 5. Elsevier.

Madrian, Brigitte, and Dennis Shea. 2001. "The Power of suggestion: Inertia in 401(k) participation and savings behavior.” Quarterly Journal of Economics, 116(4): 1149-1187.

Marx, Benjamin, and Lesley Turner. 2019. "Student loan nudges: Experimental evidence on borrowing and educational attainment.” American Economic Journal: Economic Policy, 11(2): 108-141.

Michelmore, Katherine, and Susan Dynarski. 2017. "The gap within the gap: Using longitudinal data to understand income differences in educational outcomes." AERA Open, 3(1): 2332858417692958.

Mullainathan, Sendhil, and Eldar Shafir. 2013. Scarcity: Why having too little means so much. Macmillan.

Niederle, Muriel, and Lise Vesterlund. 2007. "Do women shy away from competition? Do men compete too much?" The quarterly journal of economics, 122(3): 1067-1101.

Oreopoulos, Philip, and Reuben Ford. 2019. "Keeping college options open: A field experiment to help all high school seniors through the college application process." Journal of Policy Analysis and Management, 38(2): 426-454.

Oreopoulos, Philip, and Ryan Dunn. 2013. "Information and college access: Evidence from a randomized field experiment." The Scandinavian Journal of Economics, 115(1): 3-26.

Pallais, Amanda. 2015. "Small differences that matter: mistakes in applying to college." Journal of Labor Economics, 33(2): 493-520.

Patterson, Richard, Nolan Pope, and Aaron Feudo. 2019. “Timing is Everything: Evidence from College Major Decisons." CESifo Working Paper.

Roderick, Melissa, Vanessa Coca, and Jenny Nagaoka. 2011. "Potholes on the road to college: High school effects in shaping urban students' participation in college application, four-year college enrollment, and college match." Sociology of Education, 84(3): 178-211.

Scott-Clayton, Judith. 2012. "What explains trends in labor supply among U.S. undergraduates." National Tax Journal, 65(1): 181-210.

Smith, Jonathan, Matea Pender, and Jessica Howell. 2013. "The full extent of student-college academic undermatch." Economics of Education Review, 32: 247-261.

Stanovich, Keith E, Richard F West, and Maggie E Toplak. 2012. "Judgment and decision making in adolescence: Separating intelligence from rationality." In The adolescent brain: Learning, reasoning, and decision making. , ed. Valerie F Reyna, Sandra B Chapman, Michael R Dougherty and Jere Confrey, 337-378. American Psychological Association.

Zimmerman, Seth D. 2014. "The returns to college admission for academically marginal students." Journal of Labor Economics, 32(4): 711-754. 
For Online Publication: Appendices

A HAIL Materials

A.1 Student Packet

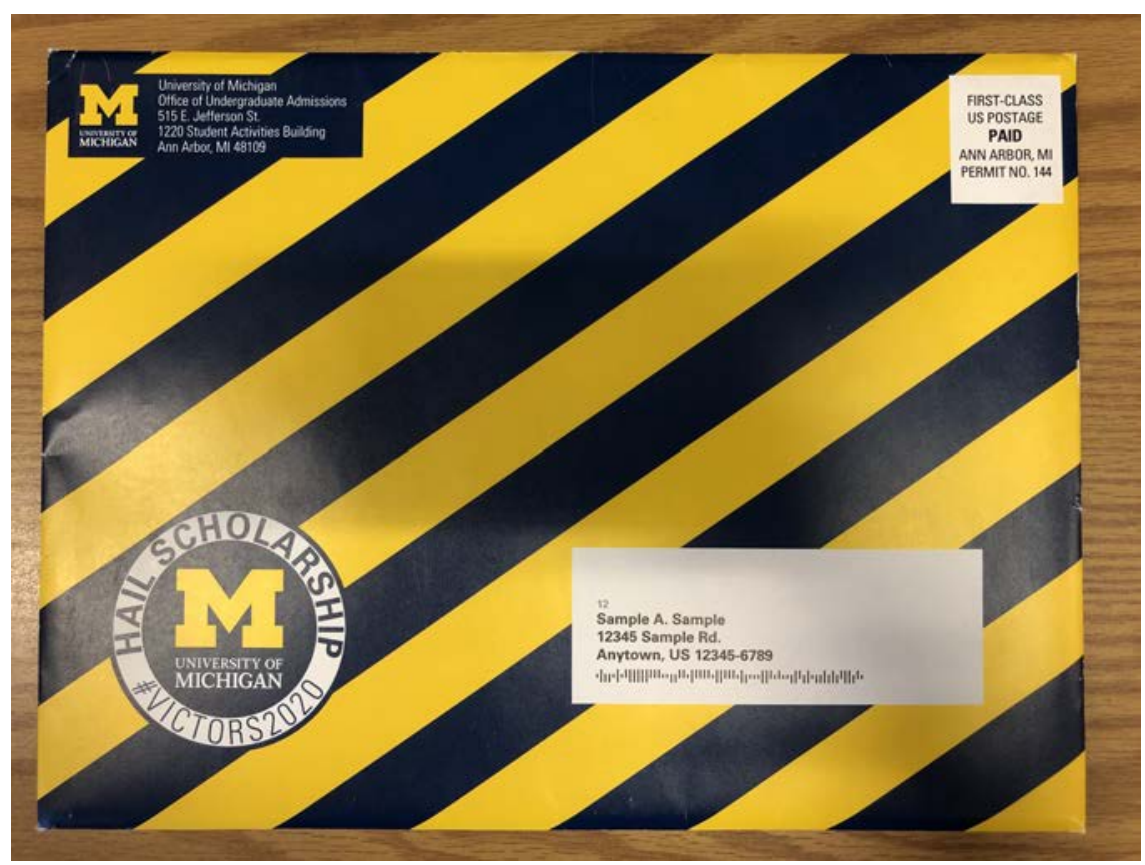

Exhibit I Front view of packet

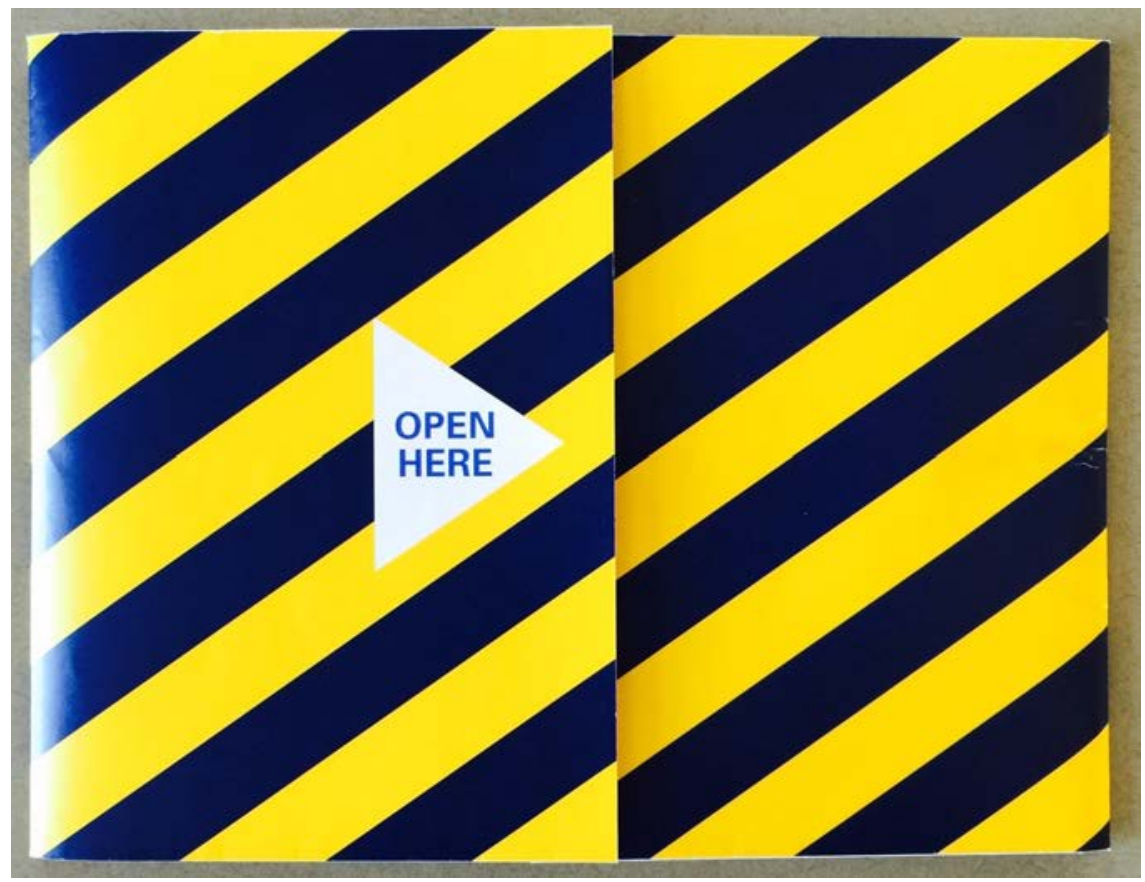

Exhibit II Back view of packet 


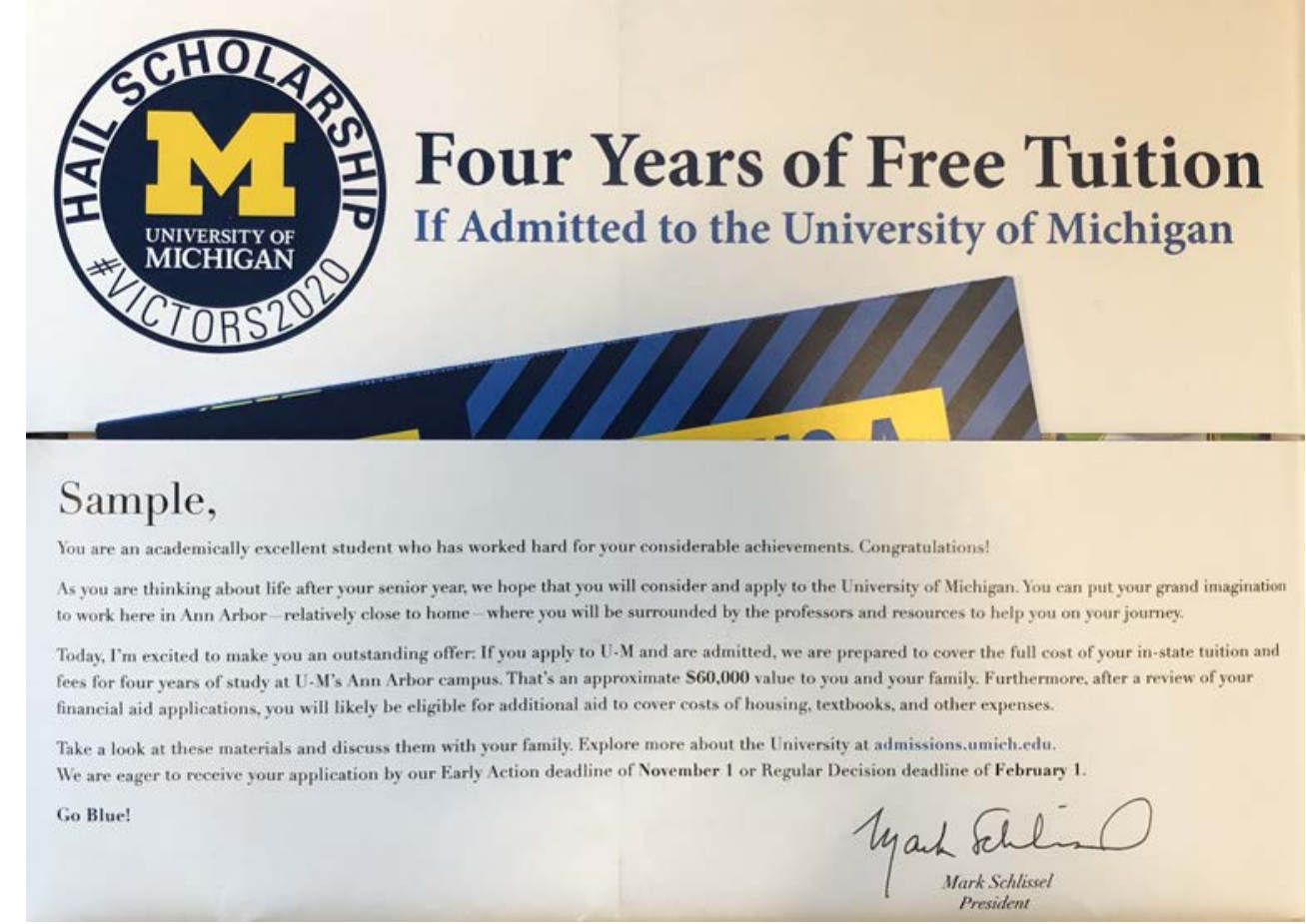

Exhibit III Inside flap of packet

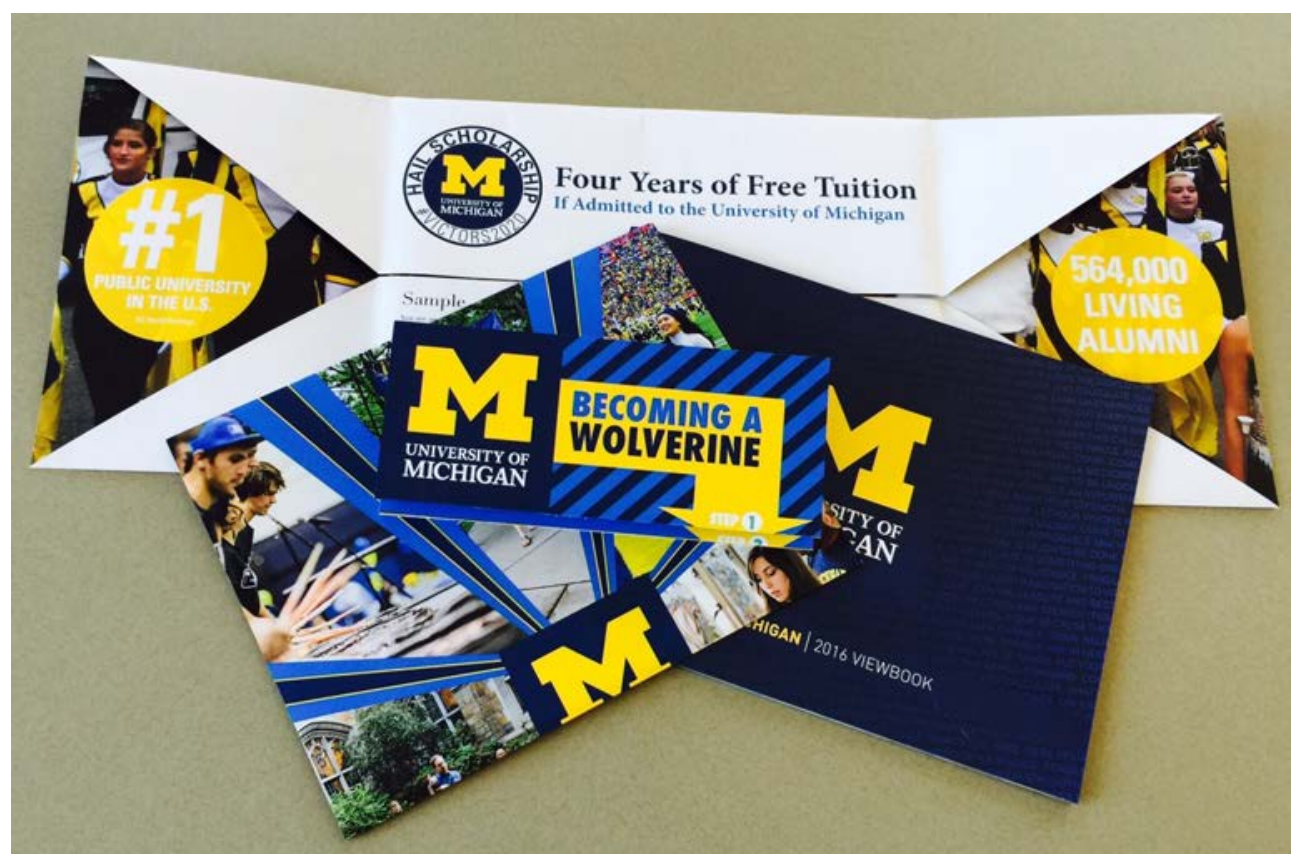

Exhibit IV Open view of packet; insert materials 


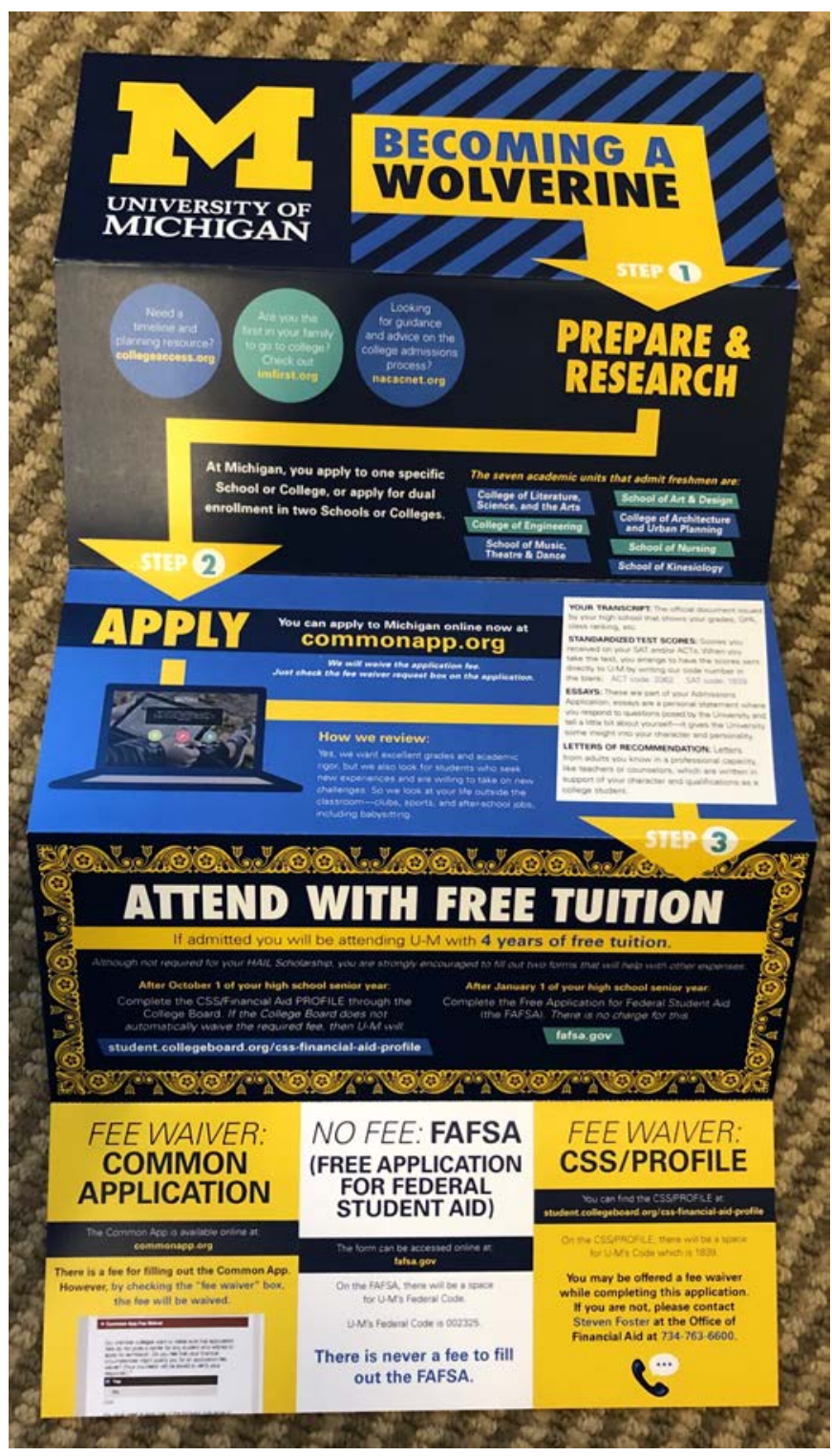

Exhibit V Packet insert: Becoming a Wolverine Guide 


\section{A.2 Parent Letter}

Dear Parent or Guardian of $<<$ first name $>><$ last name $>>$ :

Success in life is due, in part, to seizing opportunities as they are presented. Since your child is an excellent student, we want to offer a potentially transformative college opportunity: If $<<$ first name $>>$ applies and is admitted to the University of Michigan - Ann Arbor, your child will be awarded the HAIL Scholarship covering the entire cost of U-M tuition and fees for four years. This is an offer we are delighted to make, worth approximately $\$ 60,000$. Furthermore, after a review of their financial aid applications, your student will likely be eligible for additional aid to cover other costs such as housing and textbooks.

The ability to pay for college shouldn't determine whether or not a child attends. All academically high-achieving seniors, like $<<$ first name $>>$, have worked hard and challenged themselves throughout high school, and deserve access to an outstanding college experience. A world of opportunity is within reach in Ann Arbor-relatively close to home-where one of the top 25 universities in the world offers the resources and support that enables our students to stay in school, graduate, and achieve great things.

$<<$ first name $>>$ should have recently received a separate packet in the mail with more information on applying to Michigan. We know the process can be challenging, and we want to assure you that we're here to support $<<$ first name $>>$ and make it as easy as possible.

We encourage your student to apply for admission by our November 1 Early Action deadline, or no later than our February 1 Regular Decision deadline. Our brochure shows the steps to applying through the Common Application, with the $\$ 75$ fee waived. We will also waive the $\$ 25$ application fee for the CSS/Profile, which is available October 1 and will enable your student to be considered for additional aid from U-M. The Free Application for Federal Student Aid (FAFSA) will be open January 1, 2016, and will likely provide your student additional federal aid to cover other costs.

You and $<<$ first name $>>$ can also visit a special website together to find out more information about how your student was selected for this scholarship, as well as contact information for personal U-M admissions and financial aid counselors, and a place to sign up for a free U-M t-shirt. Your student's packet contains their personalized website address.

At Michigan, we're deeply committed to college access and equity for Michigan high school students. I'm excited to offer this unique opportunity to attend one of the world's premier universities with tuition and fees completely covered, should your student apply and be admitted.

If you have any questions, do not hesitate to contact Jody Gore in our Office of Undergraduate Admissions at 734-764-7433, or Steven Foster in our Office of Financial Aid at 734-763-2941.

Sincerely,

Kedra Ishop, $\mathrm{PhD}$

Associate Vice President

Office of Enrollment Management 


\section{A.3 Principal Letter}

\section{Dear $\{$ PRINCIPAL FIRST $\}$ PRINCIPAL LAST $\}$,}

I'm delighted to inform you that several seniors in your school are eligible for our pilot HAIL Scholarship, an outstanding offer of four years of free in-state tuition and fees at the University of Michigan - Ann Arbor, a value of about $\$ 60,000$ per student. Furthermore, they will likely qualify for more aid to cover additional expenses such as housing and textbooks if they apply for aid.

As a public institution committed to the well-being of the residents of the state of Michigan, we want to increase academic opportunities among Michigan's high-achieving, low-income teens. The HAIL Scholarship is a unique effort to show talented seniors who qualify for free or reduced lunch that a world of opportunity is accessible relatively close to home.

The list of your students who qualify for the scholarship is attached. We hope you might meet with them and tell them a little about the University of Michigan, our stellar academic ranking, renowned professors, and near-limitless list of majors. You can see more at admissions.umich.edu.

The students will receive an information packet from us, which outlines how they apply to Michigan through the Common Application - with their $\$ 75$ admissions fee waived - and instructions on how to file the correct forms and documentation for additional financial aid. Students will need to file the Free Application for Federal Student Aid (FAFSA) when it opens Jan. 1, and the CSS/Profile, which opens Oct. 1, to receive likely additional aid to cover other expenses. We will waive the \$25 CSS/Profile processing fee.

Students will also be given a link to a personalized scholarship website, which provides even more clarification about the scholarship, and a connection to personal U-M admissions and financial aid counselors.

We are excited to offer this special scholarship opportunity, and we hope your eligible students take advantage of it by applying before our Early Action deadline of November 1, or no later than our Regular Decision deadline of February 1.

If you have any questions, please feel free to contact Jody Gore in the Office of Undergraduate Admissions at 734-764-7433, Steven Foster in the Office of Financial Aid at 734-763-2941, or your school's U-M admissions counselor, who can be found here: http://admissions.umich.edu/contact-us Go Blue!

\section{Sincerely,}

Kedra Ishop, PhD

Associate Vice President

Office of Enrollment Management

University of Michigan - Ann Arbor HAIL Scholarship-eligible students.

Please inform your University of Michigan - Ann Arbor admissions counselor if a student no longer attends your school.

$\{$ STUDENT FIRST $\}\{$ STUDENT LAST $\},\{$ BIRTHDATE $\}$ 


\section{B Randomization-Based Inference}

The effects presented here are extremely large and are unlikely to have occurred by chance. We demonstrate this with a simulation exercise following Athey and Imbens (2017), who recommend randomizationbased statistical inference for significance tests. This approach calculates the likelihood of obtaining the observed treatment effects by random chance, where the randomness comes from assignment of a fixed number of units (in our case, high schools) to treatment, rather than from random sampling from a population.

Using the first and second cohorts of 1,026 schools, we re-assign treatment status using the same procedure used in the original randomization. We then estimate "treatment effects" based on this reassignment. We repeat this procedure 10,000 times to generate a distribution of potential treatment effects that could be due to baseline differences between schools assigned to treatment and control. For each outcome, we calculate the share of the 10,000 simulated treatment-control differences that is larger in absolute value than the difference observed in the actual random assignment discussed throughout the paper. This proportion represents the randomization-based p-value.

The results are summarized in Appendix Figure III, where we plot the distribution of treatment effects from the 10,000 iterations for a selection of outcomes. The dashed vertical line in each graph plots the actual treatment effect. Results are also presented in Appendix Table VI.

Our findings cannot be explained by random differences between the treatment and control schools. As we would expect under successful randomization, for each outcome the average simulated treatment effect is zero, indicating no difference between the randomly-assigned treated and control schools in average outcomes over 10,000 iterations.

For our key outcome, enrollment at University of Michigan, we never observe a simulated treatment effect as large as the actual treatment effect in any of the 10,000 iterations. In other words, the randomizationbased p-value is precisely zero. For the other outcomes, the randomization-based p-values are comparable to the sampling-based p-values shown earlier in the paper. For example, we showed earlier that the offer of HAIL increased college enrollment by 3.9 percentage points, with a sampling-based p-value of 0.031 . In the simulations, we observe a treatment effect this large 385 times out of 10,000 , or 3.9 percent of the time (a randomization-based p-value of 0.039).

For enrollment at any highly selective institution and enrollment at a four-year institution, there is less than a four percent chance of observing an effect at least as large as the actual treatment effect in the 10,000 simulations. Although they represent different conceptual approaches, the sampling-based and randomization-based analyses produce virtually identical conclusions about the effects of the HAIL intervention. 


\section{Appendix Tables}

\section{Appendix Table I}

Number of Students in Schools in Treatment and Control Group, by Cohort

\begin{tabular}{lcc}
\hline & $\begin{array}{c}\text { Number of } \\
\text { schools }\end{array}$ & $\begin{array}{c}\text { Number of } \\
\text { students }\end{array}$ \\
\hline \hline $\begin{array}{l}\text { First cohort } \\
\text { Treatment }\end{array}$ & 262 & 1,057 \\
Control & 267 & 1,051 \\
& & \\
Total Y1 & 529 & 2,108 \\
& & \\
Second cohort & & \\
Treatment (from Y1) & 211 & 832 \\
Treatment (newly randomized) & 27 & 43 \\
Treated in Y1, no HAIL students in Y2 & 51 & - \\
Total Treatment & 238 & 875 \\
& & \\
Control (from Y1) & 227 & 867 \\
Control (newly randomized) & 32 & 60 \\
Control in Y1, no HAIL students in Y2 & 40 & - \\
Total Control & 259 & 927 \\
& & \\
Total Y2 & 497 & 1,802 \\
\hline
\end{tabular}

Source: Michigan administrative data.

\section{Appendix Table II}

Balance Table: Full Set of School Characteristics First and Second HAIL Cohorts

\begin{tabular}{lccc}
\hline \multirow{2}{*}{ Characteristic } & \multicolumn{2}{c}{ Mean } & \\
\cline { 2 - 3 } \multicolumn{1}{c}{ Region, urbanicity, and distance } & Control schools & Treated schools & P-value \\
\hline \hline Upper Peninsula & 0.150 & 0.130 & 0.344 \\
West Central & $(0.016)$ & $(0.015)$ & \\
Southeast & 0.449 & 0.476 & 0.359 \\
& $(0.022)$ & $(0.022)$ & \\
Suburban & 0.401 & 0.394 & 0.788 \\
City & $(0.021)$ & $(0.022)$ & \\
& 0.340 & 0.360 & 0.537 \\
Rural & $(0.021)$ & $(0.021)$ & \\
& 0.129 & 0.100 & 0.148 \\
Distance from UM & $(0.015)$ & $(0.013)$ & \\
& 0.530 & 0.540 & 0.718 \\
& $(0.022)$ & $(0.022)$ & \\
& 93.2 & 96.4 & 0.529
\end{tabular}


Appendix Table II (Continued)

Balance Table: Full Set of School Characteristics

First and Second HAIL Cohorts

\begin{tabular}{|c|c|c|c|}
\hline \multirow[b]{2}{*}{ Characteristic } & \multicolumn{2}{|c|}{ Mean } & \multirow[b]{2}{*}{ P-value } \\
\hline & Control schools & Treated schools & \\
\hline \multicolumn{4}{|l|}{ Student demographic characteristics } \\
\hline Proportion female & $\begin{array}{c}0.571 \\
(0.015)\end{array}$ & $\begin{array}{c}0.605 \\
(0.015)\end{array}$ & 0.112 \\
\hline Proportion white or Asian & $\begin{array}{c}0.834 \\
(0.013)\end{array}$ & $\begin{array}{c}0.844 \\
(0.012)\end{array}$ & 0.576 \\
\hline Proportion black & $\begin{array}{c}0.094 \\
(0.011)\end{array}$ & $\begin{array}{c}0.087 \\
(0.010)\end{array}$ & 0.618 \\
\hline Proportion other race/ethnicity & $\begin{array}{c}0.072 \\
(0.009)\end{array}$ & $\begin{array}{c}0.069 \\
(0.008)\end{array}$ & 0.803 \\
\hline Proportion free lunch eligible & $\begin{array}{c}0.709 \\
(0.014)\end{array}$ & $\begin{array}{c}0.692 \\
(0.015)\end{array}$ & 0.459 \\
\hline $\begin{array}{l}\text { Proportion reduced-price lunch } \\
\text { eligible }\end{array}$ & $\begin{array}{c}0.291 \\
(0.014)\end{array}$ & $\begin{array}{c}0.308 \\
(0.015)\end{array}$ & 0.459 \\
\hline \multicolumn{4}{|l|}{ Student academic characteristics } \\
\hline Average SAT (or equivalent) & $\begin{array}{c}1254 \\
(2.690)\end{array}$ & $\begin{array}{c}1260 \\
(2.896)\end{array}$ & 0.194 \\
\hline Average GPA & $\begin{array}{c}3.82 \\
(0.006)\end{array}$ & $\begin{array}{c}3.83 \\
(0.006)\end{array}$ & 0.208 \\
\hline Proportion limited English proficient & $\begin{array}{c}0.002 \\
(0.001)\end{array}$ & $\begin{array}{c}0.004 \\
(0.001)\end{array}$ & 0.410 \\
\hline $\begin{array}{l}\text { Proportion receiving special } \\
\text { education services }\end{array}$ & $\begin{array}{c}0.009 \\
(0.003)\end{array}$ & $\begin{array}{c}0.013 \\
(0.004)\end{array}$ & 0.367 \\
\hline $\begin{array}{l}\text { Proportion who sent ACT/SAT } \\
\text { scores to UM }\end{array}$ & $\begin{array}{c}0.365 \\
(0.015)\end{array}$ & $\begin{array}{c}0.377 \\
(0.016)\end{array}$ & 0.695 \\
\hline UM application rate in 2015 & $\begin{array}{c}0.067 \\
(0.004)\end{array}$ & $\begin{array}{c}0.055 \\
(0.004)\end{array}$ & 0.016 \\
\hline Missing 2015 app rate & $\begin{array}{c}0.004 \\
(0.003)\end{array}$ & $\begin{array}{c}0.020 \\
(0.006)\end{array}$ & 0.015 \\
\hline \multicolumn{4}{|l|}{ School size } \\
\hline \# of 11th grade students in school & $\begin{array}{c}189.1 \\
(6.188)\end{array}$ & $\begin{array}{c}175.1 \\
(6.126)\end{array}$ & 0.055 \\
\hline \# of HAIL students in school & $\begin{array}{c}3.8 \\
(0.140)\end{array}$ & $\begin{array}{c}3.9 \\
(0.163)\end{array}$ & 0.649 \\
\hline Number of schools & 526 & 500 & 1,026 \\
\hline Number of students & 1,978 & 1,978 & 3,910 \\
\hline
\end{tabular}

Source: Michigan administrative data and University of Michigan Office of Enrollment Management data.

Notes: All analyses done at the school-year level. P-values are from a t-test of the coefficient on treatment status from a regression of the characteristic on treatment and strata dummies. "Other race/ethnicity" includes Hispanic, American Indian or Alaska Native, and Native Hawaiian or other Pacific Islander students. 


\section{Appendix Table III}

Balance Table: School Characteristics by Subgroup First and Second HAIL Cohorts

\begin{tabular}{|c|c|c|c|c|c|c|c|c|c|}
\hline & \multicolumn{3}{|c|}{ Upper Peninsula } & \multicolumn{3}{|c|}{ West Central } & \multicolumn{3}{|c|}{ Southeast } \\
\hline & Control & Treatment & P-value & Control & Treatment & P-value & Control & Treatment & P-value \\
\hline Upper Peninsula & - & - & - & - & - & - & - & - & - \\
\hline West Central & - & - & - & - & - & - & - & - & - \\
\hline Southeast & - & - & - & - & - & - & - & - & - \\
\hline Suburban & 0.000 & 0.000 & - & $\begin{array}{c}0.157 \\
(0.024)\end{array}$ & $\begin{array}{c}0.176 \\
(0.025)\end{array}$ & 0.429 & $\begin{array}{c}0.673 \\
(0.032)\end{array}$ & $\begin{array}{c}0.701 \\
(0.033)\end{array}$ & 0.944 \\
\hline City & 0.000 & 0.000 & - & $\begin{array}{c}0.153 \\
(0.023)\end{array}$ & $\begin{array}{c}0.118 \\
(0.021)\end{array}$ & 0.294 & $\begin{array}{c}0.2 \\
(0.025)\end{array}$ & $\begin{array}{c}0.1 \\
(0.022)\end{array}$ & 0.338 \\
\hline Rural & 1.000 & 1.000 & - & $\begin{array}{c}0.691 \\
(0.030)\end{array}$ & $\begin{array}{c}0.706 \\
(0.030)\end{array}$ & 0.878 & $\begin{array}{c}0.175 \\
(0.026)\end{array}$ & $\begin{array}{c}0.188 \\
(0.028)\end{array}$ & 0.439 \\
\hline Distance from UM & $\begin{array}{c}243.3 \\
(9.872)\end{array}$ & $\begin{array}{c}268.1 \\
(10.240)\end{array}$ & 0.139 & $\begin{array}{c}97.5 \\
(2.138)\end{array}$ & $\begin{array}{c}98.8 \\
(2.155)\end{array}$ & 0.544 & $\begin{array}{c}32.2 \\
(1.044)\end{array}$ & $\begin{array}{c}36.7 \\
(1.110)\end{array}$ & 0.004 \\
\hline Proportion female & $\begin{array}{c}0.569 \\
(0.041)\end{array}$ & $\begin{array}{c}0.615 \\
(0.048)\end{array}$ & 0.369 & $\begin{array}{c}0.563 \\
(0.023)\end{array}$ & $\begin{array}{c}0.593 \\
(0.024)\end{array}$ & 0.365 & $\begin{array}{c}0.580 \\
(0.024)\end{array}$ & $\begin{array}{c}0.617 \\
(0.022)\end{array}$ & 0.215 \\
\hline Proportion white or Asian & $\begin{array}{c}0.894 \\
(0.028)\end{array}$ & $\begin{array}{c}0.904 \\
(0.027)\end{array}$ & 0.818 & $\begin{array}{c}0.868 \\
(0.016)\end{array}$ & $\begin{array}{c}0.861 \\
(0.017)\end{array}$ & 0.774 & $\begin{array}{c}0.772 \\
(0.025)\end{array}$ & $\begin{array}{c}0.803 \\
(0.022)\end{array}$ & 0.472 \\
\hline Proportion black & $\begin{array}{c}0.034 \\
(0.016)\end{array}$ & $\begin{array}{c}0.019 \\
(0.016)\end{array}$ & 0.434 & $\begin{array}{c}0.052 \\
(0.010)\end{array}$ & $\begin{array}{c}0.055 \\
(0.011)\end{array}$ & 0.802 & $\begin{array}{c}0.165 \\
(0.022)\end{array}$ & $\begin{array}{c}0.148 \\
(0.020)\end{array}$ & 0.734 \\
\hline $\begin{array}{r}\text { Proportion other } \\
\text { race/ethnicity }\end{array}$ & $\begin{array}{c}0.072 \\
(0.024)\end{array}$ & $\begin{array}{c}0.077 \\
(0.023)\end{array}$ & 0.809 & $\begin{array}{c}0.080 \\
(0.013)\end{array}$ & $\begin{array}{c}0.083 \\
(0.013)\end{array}$ & 0.867 & $\begin{array}{c}0.063 \\
(0.014)\end{array}$ & $\begin{array}{c}0.049 \\
(0.011)\end{array}$ & 0.444 \\
\hline $\begin{array}{r}\text { Proportion free lunch } \\
\text { eligible }\end{array}$ & $\begin{array}{c}0.702 \\
(0.039)\end{array}$ & $\begin{array}{c}0.575 \\
(0.049)\end{array}$ & 0.065 & $\begin{array}{c}0.690 \\
(0.022)\end{array}$ & $\begin{array}{c}0.671 \\
(0.022)\end{array}$ & 0.500 & $\begin{array}{c}0.732 \\
(0.021)\end{array}$ & $\begin{array}{c}0.756 \\
(0.019)\end{array}$ & 0.320 \\
\hline $\begin{array}{r}\text { Proportion reduced-price } \\
\text { lunch eligible }\end{array}$ & $\begin{array}{c}0.298 \\
(0.039)\end{array}$ & $\begin{array}{c}0.425 \\
(0.049)\end{array}$ & 0.065 & $\begin{array}{c}0 \\
(0.022)\end{array}$ & $\begin{array}{c}0 \\
(0.022)\end{array}$ & 0.500 & $\begin{array}{c}0.268 \\
(0.021)\end{array}$ & $\begin{array}{c}0.244 \\
(0.019)\end{array}$ & 0.320 \\
\hline $\begin{array}{r}\text { Average SAT (or } \\
\text { equivalent) }\end{array}$ & $\begin{array}{c}1253 \\
(7.340)\end{array}$ & $\begin{array}{c}1252 \\
(8.268)\end{array}$ & 0.846 & $\begin{array}{c}1252 \\
(4.033)\end{array}$ & $\begin{array}{c}1257 \\
(4.094)\end{array}$ & 0.318 & $\begin{array}{c}1257 \\
(4.145)\end{array}$ & $\begin{array}{c}1265 \\
(4.696)\end{array}$ & 0.252 \\
\hline Average GPA & $\begin{array}{c}3.846 \\
(0.018)\end{array}$ & $\begin{array}{c}3.850 \\
(0.017)\end{array}$ & 0.813 & $\begin{array}{c}3.831 \\
(0.008)\end{array}$ & $\begin{array}{c}3.837 \\
(0.008)\end{array}$ & 0.659 & $\begin{array}{c}3.806 \\
(0.009)\end{array}$ & $\begin{array}{c}3.822 \\
(0.009)\end{array}$ & 0.170 \\
\hline $\begin{array}{r}\text { Proportion limited English } \\
\text { proficient }\end{array}$ & 0.000 & 0.000 & - & $\begin{array}{c}0.003 \\
(0.002)\end{array}$ & $\begin{array}{c}0.003 \\
(0.001)\end{array}$ & 0.898 & $\begin{array}{c}0.003 \\
(0.002)\end{array}$ & $\begin{array}{c}0.006 \\
(0.003)\end{array}$ & 0.351 \\
\hline Proportion special ed & $\begin{array}{c}0.000 \\
(0.000)\end{array}$ & $\begin{array}{c}0.005 \\
(0.005)\end{array}$ & 0.286 & $\begin{array}{c}0.011 \\
(0.005)\end{array}$ & $\begin{array}{c}0.021 \\
(0.007)\end{array}$ & 0.339 & $\begin{array}{c}0.009 \\
(0.004)\end{array}$ & $\begin{array}{c}0.006 \\
(0.003)\end{array}$ & 0.523 \\
\hline $\begin{array}{l}\text { Proportion who sent } \\
\text { ACT/SAT scores to UM }\end{array}$ & $\begin{array}{c}0.305 \\
(0.037)\end{array}$ & $\begin{array}{c}0.286 \\
(0.042)\end{array}$ & 0.605 & $\begin{array}{c}0.372 \\
(0.023)\end{array}$ & $\begin{array}{c}0.360 \\
(0.023)\end{array}$ & 0.679 & $\begin{array}{c}0.380 \\
(0.025)\end{array}$ & $\begin{array}{c}0.426 \\
(0.025)\end{array}$ & 0.273 \\
\hline UM application rate in 2015 & $\begin{array}{c}0.045 \\
(0.006)\end{array}$ & $\begin{array}{c}0.025 \\
(0.004)\end{array}$ & 0.009 & $\begin{array}{c}0.055 \\
(0.004)\end{array}$ & $\begin{array}{c}0.042 \\
(0.003)\end{array}$ & 0.011 & $\begin{array}{c}0.090 \\
(0.007)\end{array}$ & $\begin{array}{c}0.084 \\
(0.009)\end{array}$ & 0.497 \\
\hline Missing 2015 app rate & $\begin{array}{c}0.013 \\
(0.013)\end{array}$ & $\begin{array}{c}0.000 \\
(0.000)\end{array}$ & 0.335 & $\begin{array}{c}0.000 \\
(0.000)\end{array}$ & $\begin{array}{c}0.013 \\
(0.007)\end{array}$ & 0.080 & $\begin{array}{c}0.005 \\
(0.005)\end{array}$ & $\begin{array}{c}0.036 \\
(0.013)\end{array}$ & 0.023 \\
\hline $\begin{array}{r}\text { \# of 11th grade students } \\
\text { in school }\end{array}$ & $\begin{array}{c}94.4 \\
(10.008)\end{array}$ & $\begin{array}{c}77.8 \\
(7.832)\end{array}$ & 0.199 & $\begin{array}{c}162.9 \\
(6.832)\end{array}$ & $\begin{array}{c}145.5 \\
(6.848)\end{array}$ & 0.151 & $\begin{array}{c}253.8 \\
(11.257)\end{array}$ & $\begin{array}{c}242.8 \\
(11.075)\end{array}$ & 0.081 \\
\hline $\begin{array}{r}\text { \# of HAIL students } \\
\text { in school }\end{array}$ & $\begin{array}{c}2.9 \\
(0.235)\end{array}$ & $\begin{array}{c}2.8 \\
(0.312)\end{array}$ & 0.789 & $\begin{array}{c}3.6 \\
(0.159)\end{array}$ & $\begin{array}{c}3.4 \\
(0.187)\end{array}$ & 0.849 & $\begin{array}{c}4.3 \\
(0.282)\end{array}$ & $\begin{array}{c}4.8 \\
(0.320)\end{array}$ & 0.921 \\
\hline Number of school-years & 79 & 65 & 144 & 236 & 238 & 474 & 211 & 197 & 408 \\
\hline Number of students & 231 & 185 & 416 & 842 & 804 & 1646 & 905 & 943 & 1848 \\
\hline
\end{tabular}


Appendix Table III (Continued)

Balance Table: School Characteristics by Subgroup

First and Second HAIL Cohorts

\begin{tabular}{|c|c|c|c|c|c|c|c|c|c|}
\hline & \multicolumn{3}{|c|}{ Suburb } & \multicolumn{3}{|c|}{ City } & \multicolumn{3}{|c|}{ Rural } \\
\hline & Control & Treatment & P-value & Control & Treatment & P-value & Control & Treatment & P-value \\
\hline Upper Peninsula & 0.000 & 0.000 & - & 0.000 & 0.000 & - & $\begin{array}{c}0.283 \\
(0.027)\end{array}$ & $\begin{array}{c}0.241 \\
(0.026)\end{array}$ & 0.235 \\
\hline West Central & $\begin{array}{c}0.207 \\
(0.030)\end{array}$ & $\begin{array}{c}0.233 \\
(0.032)\end{array}$ & 0.602 & $\begin{array}{c}0.529 \\
(0.061)\end{array}$ & $\begin{array}{c}0.560 \\
(0.071)\end{array}$ & 0.784 & $\begin{array}{c}0.584 \\
(0.030)\end{array}$ & $\begin{array}{c}0.622 \\
(0.030)\end{array}$ & 0.320 \\
\hline Southeast & $\begin{array}{c}0.793 \\
(0.030)\end{array}$ & $\begin{array}{c}0.767 \\
(0.032)\end{array}$ & 0.602 & $\begin{array}{c}0.471 \\
(0.061)\end{array}$ & $\begin{array}{c}0.440 \\
(0.071)\end{array}$ & 0.784 & $\begin{array}{c}0.133 \\
(0.020)\end{array}$ & $\begin{array}{l}0.137 \\
(0.021)\end{array}$ & 0.917 \\
\hline Suburban & - & - & - & - & - & - & - & - & - \\
\hline City & - & - & - & - & - & - & - & - & - \\
\hline Rural & - & - & - & - & - & - & - & - & - \\
\hline Distance from UM & $\begin{array}{c}46.8 \\
(2.484)\end{array}$ & $\begin{array}{c}52.3 \\
(2.570)\end{array}$ & 0.150 & $\begin{array}{c}65.1 \\
(5.258)\end{array}$ & $\begin{array}{c}64.5 \\
(4.996)\end{array}$ & 0.829 & $\begin{array}{c}129.9 \\
(5.485)\end{array}$ & $\begin{array}{l}131.6 \\
(5.695)\end{array}$ & 0.856 \\
\hline Proportion female & $\begin{array}{c}0.557 \\
(0.025)\end{array}$ & $\begin{array}{c}0.620 \\
(0.021)\end{array}$ & 0.054 & $\begin{array}{c}0.574 \\
(0.042)\end{array}$ & $\begin{array}{c}0.575 \\
(0.052)\end{array}$ & 0.975 & $\begin{array}{c}0.579 \\
(0.022)\end{array}$ & $\begin{array}{c}0.601 \\
(0.023)\end{array}$ & 0.424 \\
\hline Proportion white or Asian & $\begin{array}{c}0.845 \\
(0.021)\end{array}$ & $\begin{array}{c}0.810 \\
(0.021)\end{array}$ & 0.132 & $\begin{array}{c}0.574 \\
(0.049)\end{array}$ & $\begin{array}{c}0.574 \\
(0.059)\end{array}$ & 0.835 & $\begin{array}{c}0.890 \\
(0.015)\end{array}$ & $\begin{array}{c}0.916 \\
(0.012)\end{array}$ & 0.156 \\
\hline Proportion black & $\begin{array}{c}0.104 \\
(0.018)\end{array}$ & $\begin{array}{c}0.151 \\
(0.020)\end{array}$ & 0.037 & $\begin{array}{c}0.308 \\
(0.049)\end{array}$ & $\begin{array}{c}0.212 \\
(0.048)\end{array}$ & 0.115 & $\begin{array}{c}0.036 \\
(0.009)\end{array}$ & $\begin{array}{c}0.022 \\
(0.007)\end{array}$ & 0.186 \\
\hline $\begin{array}{l}\text { Proportion other } \\
\text { race/ethnicity }\end{array}$ & $\begin{array}{c}0.051 \\
(0.013)\end{array}$ & $\begin{array}{c}0.039 \\
(0.008)\end{array}$ & 0.406 & $\begin{array}{c}0.118 \\
(0.030)\end{array}$ & $\begin{array}{c}0.214 \\
(0.046)\end{array}$ & 0.082 & $\begin{array}{c}0.074 \\
(0.012)\end{array}$ & $\begin{array}{c}0.062 \\
(0.010)\end{array}$ & 0.428 \\
\hline $\begin{array}{r}\text { Proportion free lunch } \\
\text { eligible }\end{array}$ & $\begin{array}{c}0.712 \\
(0.022)\end{array}$ & $\begin{array}{c}0.740 \\
(0.019)\end{array}$ & 0.224 & $\begin{array}{c}0.838 \\
(0.030)\end{array}$ & $\begin{array}{c}0.768 \\
(0.050)\end{array}$ & 0.192 & $\begin{array}{c}0.675 \\
(0.021)\end{array}$ & $\begin{array}{c}0.646 \\
(0.021)\end{array}$ & 0.402 \\
\hline $\begin{array}{r}\text { Proportion reduced-price } \\
\text { lunch eligible }\end{array}$ & $\begin{array}{c}0.288 \\
(0.022)\end{array}$ & $\begin{array}{c}0.260 \\
(0.019)\end{array}$ & 0.224 & $\begin{array}{c}0.162 \\
(0.030)\end{array}$ & $\begin{array}{c}0.232 \\
(0.050)\end{array}$ & 0.192 & $\begin{array}{c}0.325 \\
(0.021)\end{array}$ & $\begin{array}{c}0.354 \\
(0.021)\end{array}$ & 0.402 \\
\hline $\begin{array}{r}\text { Average SAT (or } \\
\text { equivalent) }\end{array}$ & $\begin{array}{c}1263 \\
(4.380)\end{array}$ & $\begin{array}{c}1268 \\
(4.683)\end{array}$ & 0.833 & $\begin{array}{c}1252 \\
(7.296)\end{array}$ & $\begin{array}{c}1250 \\
(9.939)\end{array}$ & 0.875 & $\begin{array}{c}1249 \\
(3.804)\end{array}$ & $\begin{array}{l}1256 \\
(3.935)\end{array}$ & 0.174 \\
\hline Average GPA & $\begin{array}{c}3.788 \\
(0.010)\end{array}$ & $\begin{array}{l}3.820 \\
(0.009)\end{array}$ & 0.013 & $\begin{array}{c}3.828 \\
(0.016)\end{array}$ & $\begin{array}{c}3.841 \\
(0.024)\end{array}$ & 0.671 & $\begin{array}{l}3.845 \\
(0.008)\end{array}$ & $\begin{array}{l}3.839 \\
(0.008)\end{array}$ & 0.594 \\
\hline $\begin{array}{r}\text { Proportion limited English } \\
\text { proficient }\end{array}$ & $\begin{array}{c}0.002 \\
(0.002)\end{array}$ & $\begin{array}{c}0.003 \\
(0.001)\end{array}$ & 0.772 & $\begin{array}{c}0.012 \\
(0.006)\end{array}$ & $\begin{array}{c}0.019 \\
(0.012)\end{array}$ & 0.306 & $\begin{array}{c}0.000 \\
(0.000)\end{array}$ & $\begin{array}{l}0.001 \\
(0.001)\end{array}$ & 0.157 \\
\hline Proportion special ed & $\begin{array}{c}0.013 \\
(0.007)\end{array}$ & $\begin{array}{c}0.011 \\
(0.006)\end{array}$ & 0.599 & $\begin{array}{c}0.000 \\
(0.000)\end{array}$ & $\begin{array}{c}0.011 \\
(0.010)\end{array}$ & 0.278 & $\begin{array}{c}0.008 \\
(0.003)\end{array}$ & $\begin{array}{l}0.015 \\
(0.006)\end{array}$ & 0.252 \\
\hline $\begin{array}{r}\text { Proportion who sent } \\
\text { ACT/SAT scores to UM }\end{array}$ & $\begin{array}{c}0.391 \\
(0.025)\end{array}$ & $\begin{array}{c}0.397 \\
(0.024)\end{array}$ & 0.730 & $\begin{array}{c}0.386 \\
(0.044)\end{array}$ & $\begin{array}{c}0.489 \\
(0.056)\end{array}$ & 0.160 & $\begin{array}{c}0.343 \\
(0.021)\end{array}$ & $\begin{array}{c}0.342 \\
(0.022)\end{array}$ & 0.885 \\
\hline UM application rate in 2015 & $\begin{array}{c}0.089 \\
(0.007)\end{array}$ & $\begin{array}{c}0.078 \\
(0.009)\end{array}$ & 0.329 & $\begin{array}{c}0.110 \\
(0.015)\end{array}$ & $\begin{array}{c}0.098 \\
(0.014)\end{array}$ & 0.928 & $\begin{array}{l}0.043 \\
(0.003)\end{array}$ & $\begin{array}{c}0.034 \\
(0.002)\end{array}$ & 0.009 \\
\hline Missing 2015 app rate & $\begin{array}{c}0.006 \\
(0.006)\end{array}$ & $\begin{array}{c}0.028 \\
(0.012)\end{array}$ & 0.062 & $\begin{array}{c}0.000 \\
(0.000)\end{array}$ & $\begin{array}{c}0.040 \\
(0.028)\end{array}$ & 0.151 & $\begin{array}{c}0.004 \\
(0.004)\end{array}$ & $\begin{array}{c}0.011 \\
(0.006)\end{array}$ & 0.300 \\
\hline $\begin{array}{r}\text { \# of 11th grade students } \\
\text { in school }\end{array}$ & $\begin{array}{c}288 \\
(12.401)\end{array}$ & $\begin{array}{c}262.3 \\
(11.421)\end{array}$ & 0.018 & $\begin{array}{c}207.1 \\
(13.533)\end{array}$ & $\begin{array}{c}199.4 \\
(20.064)\end{array}$ & 0.814 & $\begin{array}{c}121.2 \\
(4.790)\end{array}$ & $\begin{array}{l}112.4 \\
(4.859)\end{array}$ & 0.253 \\
\hline $\begin{array}{r}\text { \# of HAIL students } \\
\text { in school }\end{array}$ & $\begin{array}{c}4.8 \\
(0.283)\end{array}$ & $\begin{array}{c}5.2 \\
(0.302)\end{array}$ & 0.986 & $\begin{array}{c}4.4 \\
(0.549)\end{array}$ & $\begin{array}{c}4.7 \\
(0.888)\end{array}$ & 0.160 & $\begin{array}{c}3 \\
(0.119)\end{array}$ & $\begin{array}{c}2.9 \\
(0.124)\end{array}$ & 0.724 \\
\hline Number of school-years & 179 & 180 & 359 & 68 & 50 & 118 & 279 & 270 & 549 \\
\hline Number of students & 852 & 932 & 1784 & 297 & 233 & 530 & 829 & 767 & 1596 \\
\hline
\end{tabular}


Appendix Table III (Continued)

Balance Table: School Characteristics by Subgroup

First and Second HAIL Cohorts

\begin{tabular}{|c|c|c|c|c|c|c|}
\hline & \multicolumn{3}{|c|}{ Male } & \multicolumn{3}{|c|}{ Female } \\
\hline & Control & Treatment & P-value & Control & Treatment & P-value \\
\hline Upper Peninsula & $\begin{array}{c}0.150 \\
(0.018)\end{array}$ & $\begin{array}{c}0.121 \\
(0.017)\end{array}$ & 0.294 & $\begin{array}{c}0.144 \\
(0.017)\end{array}$ & $\begin{array}{c}0.118 \\
(0.016)\end{array}$ & 0.267 \\
\hline West Central & $\begin{array}{c}0.446 \\
(0.026)\end{array}$ & $\begin{array}{c}0.451 \\
(0.027)\end{array}$ & 0.837 & $\begin{array}{c}0.449 \\
(0.024)\end{array}$ & $\begin{array}{c}0.456 \\
(0.024)\end{array}$ & 0.813 \\
\hline Southeast & $\begin{array}{c}0.404 \\
(0.025)\end{array}$ & $\begin{array}{c}0.428 \\
(0.027)\end{array}$ & 0.600 & $\begin{array}{c}0.407 \\
(0.024)\end{array}$ & $\begin{array}{c}0.426 \\
(0.024)\end{array}$ & 0.606 \\
\hline Suburban & $\begin{array}{c}0.360 \\
(0.025)\end{array}$ & $\begin{array}{c}0.405 \\
(0.026)\end{array}$ & 0.293 & $\begin{array}{c}0.343 \\
(0.023)\end{array}$ & $\begin{array}{l}0.400 \\
(0.024)\end{array}$ & 0.083 \\
\hline City & $\begin{array}{c}0.129 \\
(0.017)\end{array}$ & $\begin{array}{c}0.098 \\
(0.016)\end{array}$ & 0.174 & $\begin{array}{c}0.134 \\
(0.016)\end{array}$ & $\begin{array}{c}0.095 \\
(0.014)\end{array}$ & 0.065 \\
\hline Rural & $\begin{array}{c}0.512 \\
(0.026)\end{array}$ & $\begin{array}{c}0.497 \\
(0.027)\end{array}$ & 0.893 & $\begin{array}{c}0.523 \\
(0.024)\end{array}$ & $\begin{array}{c}0.506 \\
(0.024)\end{array}$ & 0.637 \\
\hline Distance from UM & $\begin{array}{c}93.6 \\
(4.241)\end{array}$ & $\begin{array}{c}91.7 \\
(4.132)\end{array}$ & 0.869 & $\begin{array}{c}91.4 \\
(3.791)\end{array}$ & $\begin{array}{c}92.7 \\
(3.877)\end{array}$ & 0.794 \\
\hline Proportion female & - & - & - & - & - & \\
\hline Proportion white or Asian & $\begin{array}{c}0.864 \\
(0.015)\end{array}$ & $\begin{array}{c}0.853 \\
(0.017)\end{array}$ & 0.547 & $\begin{array}{c}0.832 \\
(0.015)\end{array}$ & $\begin{array}{c}0.837 \\
(0.015)\end{array}$ & 0.736 \\
\hline Proportion black & $\begin{array}{c}0.066 \\
(0.011)\end{array}$ & $\begin{array}{c}0.061 \\
(0.011)\end{array}$ & 0.794 & $\begin{array}{c}0.096 \\
(0.012)\end{array}$ & $\begin{array}{c}0.101 \\
(0.012)\end{array}$ & 0.839 \\
\hline $\begin{array}{l}\text { Proportion other } \\
\text { race/ethnicity }\end{array}$ & $\begin{array}{c}0.070 \\
(0.011)\end{array}$ & $\begin{array}{c}0.086 \\
(0.013)\end{array}$ & 0.296 & $\begin{array}{c}0.072 \\
(0.010)\end{array}$ & $\begin{array}{c}0.062 \\
(0.009)\end{array}$ & 0.450 \\
\hline $\begin{array}{r}\text { Proportion free lunch } \\
\text { eligible }\end{array}$ & $\begin{array}{c}0.710 \\
(0.019)\end{array}$ & $\begin{array}{c}0.681 \\
(0.020)\end{array}$ & 0.345 & $\begin{array}{c}0.693 \\
(0.018)\end{array}$ & $\begin{array}{c}0.698 \\
(0.017)\end{array}$ & 0.765 \\
\hline $\begin{array}{r}\text { Proportion reduced-price } \\
\text { lunch eligible }\end{array}$ & $\begin{array}{c}0.290 \\
(0.019)\end{array}$ & $\begin{array}{c}0.319 \\
(0.020)\end{array}$ & 0.345 & $\begin{array}{c}0.307 \\
(0.018)\end{array}$ & $\begin{array}{c}0.302 \\
(0.017)\end{array}$ & 0.765 \\
\hline $\begin{array}{r}\text { Average SAT (or } \\
\text { equivalent) }\end{array}$ & $\begin{array}{c}1275 \\
(3.565)\end{array}$ & $\begin{array}{c}1278 \\
(4.102)\end{array}$ & 0.697 & $\begin{array}{c}1245 \\
(3.184)\end{array}$ & $\begin{array}{c}1249 \\
(3.324)\end{array}$ & 0.393 \\
\hline Average GPA & $\begin{array}{c}3.778 \\
(0.008)\end{array}$ & $\begin{array}{l}3.786 \\
(0.009)\end{array}$ & 0.466 & $\begin{array}{c}3.851 \\
(0.006)\end{array}$ & $\begin{array}{c}3.855 \\
(0.006)\end{array}$ & 0.566 \\
\hline $\begin{array}{r}\text { Proportion limited English } \\
\text { proficient }\end{array}$ & $\begin{array}{c}0.003 \\
(0.002)\end{array}$ & $\begin{array}{c}0.011 \\
(0.005)\end{array}$ & 0.203 & $\begin{array}{c}0.002 \\
(0.001)\end{array}$ & $\begin{array}{c}0.003 \\
(0.002)\end{array}$ & 0.452 \\
\hline Proportion special ed & $\begin{array}{c}0.019 \\
(0.006)\end{array}$ & $\begin{array}{c}0.017 \\
(0.006)\end{array}$ & 0.897 & $\begin{array}{c}0.004 \\
(0.002)\end{array}$ & $\begin{array}{c}0.009 \\
(0.004)\end{array}$ & 0.235 \\
\hline Proportion who sent & 0.400 & 0.422 & 0.607 & 0.337 & 0.350 & 0.711 \\
\hline ACT/SAT scores to UM & $(0.021)$ & $(0.022)$ & & $(0.018)$ & $(0.018)$ & \\
\hline UM application rate in 2015 & $\begin{array}{c}0.072 \\
(0.004)\end{array}$ & $\begin{array}{c}0.061 \\
(0.005)\end{array}$ & 0.062 & $\begin{array}{c}0.071 \\
(0.004)\end{array}$ & $\begin{array}{c}0.059 \\
(0.004)\end{array}$ & 0.048 \\
\hline Missing 2015 app rate & $\begin{array}{c}0.003 \\
(0.003)\end{array}$ & $\begin{array}{c}0.009 \\
(0.005)\end{array}$ & 0.262 & $\begin{array}{c}0.002 \\
(0.002)\end{array}$ & $\begin{array}{c}0.021 \\
(0.007)\end{array}$ & 0.009 \\
\hline $\begin{array}{r}\text { \# of 11th grade students } \\
\text { in school }\end{array}$ & $\begin{array}{c}205 \\
(7.420)\end{array}$ & $\begin{array}{l}199.5 \\
(7.793)\end{array}$ & 0.282 & $\begin{array}{l}201.7 \\
(7.041)\end{array}$ & $\begin{array}{c}188.9 \\
(6.790)\end{array}$ & 0.146 \\
\hline $\begin{array}{r}\text { \# of HAIL students } \\
\text { in school }\end{array}$ & $\begin{array}{c}4.5 \\
(0.177)\end{array}$ & $\begin{array}{c}4.7 \\
(0.214)\end{array}$ & 0.726 & $\begin{array}{c}4.2 \\
(0.161)\end{array}$ & $\begin{array}{c}4.3 \\
(0.185)\end{array}$ & 0.673 \\
\hline Number of school-years & 381 & 348 & 729 & 432 & 423 & 855 \\
\hline Number of students & 853 & 784 & 1637 & 1125 & 1148 & 2273 \\
\hline
\end{tabular}


Appendix Table III (Continued)

Balance Table: School Characteristics by Subgroup

First and Second HAIL Cohorts

\begin{tabular}{|c|c|c|c|c|c|c|c|c|c|}
\hline & \multicolumn{3}{|c|}{ White or Asian } & \multicolumn{3}{|c|}{ Black } & \multicolumn{3}{|c|}{ Other race/ethnicity } \\
\hline & Control & Treatment & $\mathrm{P}$-value & Control & Treatment & P-value & Control & Treatment & P-value \\
\hline Upper Peninsula & $\begin{array}{c}0.156 \\
(0.017)\end{array}$ & $\begin{array}{c}0.135 \\
(0.016)\end{array}$ & 0.320 & $\begin{array}{c}0.059 \\
(0.024)\end{array}$ & $\begin{array}{c}0.019 \\
(0.013)\end{array}$ & 0.147 & $\begin{array}{l}0.137 \\
(0.035)\end{array}$ & $\begin{array}{c}0.135 \\
(0.035)\end{array}$ & 0.960 \\
\hline West Central & $\begin{array}{c}0.469 \\
(0.023)\end{array}$ & $\begin{array}{c}0.485 \\
(0.023)\end{array}$ & 0.587 & $\begin{array}{c}0.327 \\
(0.047)\end{array}$ & $\begin{array}{c}0.314 \\
(0.046)\end{array}$ & 0.876 & $\begin{array}{c}0.558 \\
(0.051)\end{array}$ & $\begin{array}{c}0.562 \\
(0.051)\end{array}$ & 0.826 \\
\hline Southeast & $\begin{array}{c}0.375 \\
(0.022)\end{array}$ & $\begin{array}{c}0.380 \\
(0.022)\end{array}$ & 0.874 & $\begin{array}{c}0.614 \\
(0.049)\end{array}$ & $\begin{array}{c}0.667 \\
(0.046)\end{array}$ & 0.486 & $\begin{array}{c}0.305 \\
(0.047)\end{array}$ & $\begin{array}{c}0.302 \\
(0.047)\end{array}$ & 0.842 \\
\hline Suburban & $\begin{array}{c}0.346 \\
(0.022)\end{array}$ & $\begin{array}{c}0.359 \\
(0.022)\end{array}$ & 0.654 & $\begin{array}{c}0.446 \\
(0.050)\end{array}$ & $\begin{array}{c}0.705 \\
(0.045)\end{array}$ & 0.001 & $\begin{array}{c}0.284 \\
(0.047)\end{array}$ & $\begin{array}{c}0.312 \\
(0.048)\end{array}$ & 0.903 \\
\hline City & $\begin{array}{c}0.104 \\
(0.014)\end{array}$ & $\begin{array}{c}0.079 \\
(0.012)\end{array}$ & 0.177 & $\begin{array}{c}0.337 \\
(0.047)\end{array}$ & $\begin{array}{c}0.162 \\
(0.036)\end{array}$ & 0.011 & $\begin{array}{c}0.211 \\
(0.042)\end{array}$ & $\begin{array}{c}0.229 \\
(0.043)\end{array}$ & 0.975 \\
\hline Rural & $\begin{array}{c}0.550 \\
(0.023)\end{array}$ & $\begin{array}{c}0.562 \\
(0.023)\end{array}$ & 0.705 & $\begin{array}{c}0.218 \\
(0.041)\end{array}$ & $\begin{array}{c}0.133 \\
(0.033)\end{array}$ & 0.172 & $\begin{array}{c}0.505 \\
(0.052)\end{array}$ & $\begin{array}{c}0.458 \\
(0.051)\end{array}$ & 0.889 \\
\hline Distance from UM & $\begin{array}{c}95.6 \\
(3.728)\end{array}$ & $\begin{array}{c}97.7 \\
(3.827)\end{array}$ & 0.721 & $\begin{array}{c}66.2 \\
(6.827)\end{array}$ & $\begin{array}{c}58.1 \\
(4.231)\end{array}$ & 0.383 & $\begin{array}{c}96.7 \\
(7.448)\end{array}$ & $\begin{array}{c}102.5 \\
(8.397)\end{array}$ & 0.534 \\
\hline Proportion female & $\begin{array}{c}0.562 \\
(0.016)\end{array}$ & $\begin{array}{c}0.604 \\
(0.016)\end{array}$ & 0.061 & $\begin{array}{c}0.636 \\
(0.044)\end{array}$ & $\begin{array}{c}0.718 \\
(0.040)\end{array}$ & 0.153 & $\begin{array}{c}0.575 \\
(0.049)\end{array}$ & $\begin{array}{c}0.512 \\
(0.047)\end{array}$ & 0.452 \\
\hline Proportion white or Asian & - & - & & - & - & - & - & - & - \\
\hline Proportion black & - & - & & - & - & - & - & - & - \\
\hline $\begin{array}{l}\text { Proportion other } \\
\text { race/ethnicity }\end{array}$ & - & - & & - & - & - & - & - & - \\
\hline $\begin{array}{r}\text { Proportion free lunch } \\
\text { eligible }\end{array}$ & $\begin{array}{c}0.690 \\
(0.015)\end{array}$ & $\begin{array}{c}0.666 \\
(0.016)\end{array}$ & 0.334 & $\begin{array}{c}0.812 \\
(0.036)\end{array}$ & $\begin{array}{c}0.812 \\
(0.035)\end{array}$ & 0.608 & $\begin{array}{c}0.775 \\
(0.041)\end{array}$ & $\begin{array}{c}0.750 \\
(0.043)\end{array}$ & 0.635 \\
\hline $\begin{array}{r}\text { Proportion reduced-price } \\
\text { lunch eligible }\end{array}$ & $\begin{array}{c}0.310 \\
(0.015)\end{array}$ & $\begin{array}{c}0.334 \\
(0.016)\end{array}$ & 0.334 & $\begin{array}{c}0.188 \\
(0.036)\end{array}$ & $\begin{array}{c}0.188 \\
(0.035)\end{array}$ & 0.608 & $\begin{array}{c}0.225 \\
(0.041)\end{array}$ & $\begin{array}{c}0.250 \\
(0.043)\end{array}$ & 0.635 \\
\hline $\begin{array}{r}\text { Average SAT (or } \\
\text { equivalent) }\end{array}$ & $\begin{array}{c}1260 \\
(2.978)\end{array}$ & $\begin{array}{c}1264 \\
(3.004)\end{array}$ & 0.358 & $\begin{array}{c}1239 \\
(7.360)\end{array}$ & $\begin{array}{l}1250 \\
(6.799)\end{array}$ & 0.270 & $\begin{array}{c}1251 \\
(8.325)\end{array}$ & $\begin{array}{c}1237 \\
(8.473)\end{array}$ & 0.169 \\
\hline Average GPA & $\begin{array}{c}3.822 \\
(0.006)\end{array}$ & $\begin{array}{l}3.831 \\
(0.006)\end{array}$ & 0.270 & $\begin{array}{c}3.812 \\
(0.016)\end{array}$ & $\begin{array}{l}3.791 \\
(0.018)\end{array}$ & 0.540 & $\begin{array}{c}3.802 \\
(0.019)\end{array}$ & $\begin{array}{l}3.841 \\
(0.017)\end{array}$ & 0.126 \\
\hline $\begin{array}{r}\text { Proportion limited English } \\
\text { proficient }\end{array}$ & $\begin{array}{c}0.002 \\
(0.001)\end{array}$ & $\begin{array}{c}0.003 \\
(0.001)\end{array}$ & 0.437 & $\begin{array}{c}0.010 \\
(0.010)\end{array}$ & $\begin{array}{c}0.005 \\
(0.005)\end{array}$ & 0.657 & $\begin{array}{c}0.007 \\
(0.007)\end{array}$ & $\begin{array}{c}0.005 \\
(0.005)\end{array}$ & 0.786 \\
\hline Proportion special ed & $\begin{array}{c}0.009 \\
(0.003)\end{array}$ & $\begin{array}{l}0.013 \\
(0.004)\end{array}$ & 0.438 & $\begin{array}{c}0.005 \\
(0.005)\end{array}$ & $\begin{array}{c}0.014 \\
(0.011)\end{array}$ & 0.550 & $\begin{array}{c}0.011 \\
(0.011)\end{array}$ & $\begin{array}{c}0.016 \\
(0.012)\end{array}$ & 0.595 \\
\hline $\begin{array}{l}\text { Proportion who sent } \\
\text { ACT/SAT scores to UM }\end{array}$ & $\begin{array}{c}0.369 \\
(0.016)\end{array}$ & $\begin{array}{c}0.374 \\
(0.017)\end{array}$ & 0.919 & $\begin{array}{c}0.457 \\
(0.046)\end{array}$ & $\begin{array}{c}0.384 \\
(0.043)\end{array}$ & 0.118 & $\begin{array}{c}0.410 \\
(0.049)\end{array}$ & $\begin{array}{c}0.419 \\
(0.048)\end{array}$ & 0.902 \\
\hline UM application rate in 2015 & $\begin{array}{c}0.068 \\
(0.004)\end{array}$ & $\begin{array}{c}0.055 \\
(0.004)\end{array}$ & 0.013 & $\begin{array}{c}0.090 \\
(0.010)\end{array}$ & $\begin{array}{c}0.086 \\
(0.014)\end{array}$ & 0.713 & $\begin{array}{c}0.073 \\
(0.009)\end{array}$ & $\begin{array}{c}0.059 \\
(0.007)\end{array}$ & 0.100 \\
\hline Missing 2015 app rate & $\begin{array}{c}0.004 \\
(0.003)\end{array}$ & $\begin{array}{c}0.015 \\
(0.006)\end{array}$ & 0.089 & $\begin{array}{c}0.000 \\
(0.000)\end{array}$ & $\begin{array}{c}0.029 \\
(0.016)\end{array}$ & 0.068 & $\begin{array}{c}0.000 \\
(0.000)\end{array}$ & $\begin{array}{c}0.010 \\
(0.010)\end{array}$ & 0.342 \\
\hline $\begin{array}{r}\text { \# of 11th grade students } \\
\text { in school }\end{array}$ & $\begin{array}{c}193 \\
(6.640)\end{array}$ & $\begin{array}{c}179 \\
(6.365)\end{array}$ & 0.095 & $\begin{array}{c}234.1 \\
(12.684)\end{array}$ & $\begin{array}{c}264 \\
(16.545)\end{array}$ & 0.364 & $\begin{array}{c}205.2 \\
(12.777)\end{array}$ & $\begin{array}{l}227.1 \\
(0.000)\end{array}$ & 0.467 \\
\hline $\begin{array}{r}\text { \# of HAIL students } \\
\text { in school }\end{array}$ & $\begin{array}{c}4 \\
(0.149)\end{array}$ & $\begin{array}{c}4 \\
(0.171)\end{array}$ & 0.634 & $\begin{array}{c}4.8 \\
(0.341)\end{array}$ & $\begin{array}{c}5.8 \\
(0.503)\end{array}$ & 0.264 & $\begin{array}{c}4.8 \\
(0.307)\end{array}$ & $\begin{array}{c}6.1 \\
(0.584)\end{array}$ & 0.068 \\
\hline Number of school-years & 480 & 468 & 948 & 101 & 105 & 206 & 95 & 96 & 191 \\
\hline Number of students & 1688 & 1624 & 3312 & 162 & 168 & 330 & 128 & 140 & 268 \\
\hline
\end{tabular}

Source: Michigan administrative data.

Notes: All analyses done at the school-year level. For region and urbancity subgroups, p-values are from a t-test of the coefficient on treatment status from a regression of the characteristic on treatment and strata dummies, estimated on the subgroup. For gender and race, p-values are from separate regressions of school-subgroup-level characteristic on treatment status and strata dummies. 


\section{Appendix Table IV \\ Estimated Effect of HAIL Scholarship on Timing of Application to UM}

First and Second HAIL Cohorts

\begin{tabular}{lcc}
\hline & Treatment effect & Control mean \\
\hline \hline Applied (any) & $\begin{array}{c}0.422 \\
(0.021)\end{array}$ & 0.259 \\
& 0.321 & 0.201 \\
Applied Early Action & $(0.021)$ & \\
& 0.102 & 0.058 \\
Applied Regular Decision & $(0.014)$ & \\
& & \\
Number of school-years & \multicolumn{2}{c}{1,026} \\
Number of students & \multicolumn{2}{c}{3,910} \\
\hline
\end{tabular}

Source: Michigan administrative data and University of Michigan Office of Enrollment Management data.

Notes: All analyses done at the school-year level. Robust standard errors reported. Application measured in the summer and fall following expected high school graduation.

\begin{tabular}{|c|c|c|c|}
\hline \multicolumn{4}{|c|}{$\begin{array}{c}\text { Appendix Table V } \\
\text { iversity of Michigan Admission Rates Conditional on App } \\
\text { (Non-Experimental Results) } \\
\text { First and Second HAIL Cohorts }\end{array}$} \\
\hline & $\begin{array}{l}\text { Control } \\
\text { students }\end{array}$ & $\begin{array}{l}\text { Treated } \\
\text { students }\end{array}$ & $\begin{array}{l}\text { P-value from } \\
\text { two-way t-test }\end{array}$ \\
\hline Proportion admitted & $\begin{array}{c}0.525 \\
(0.021)\end{array}$ & $\begin{array}{c}0.456 \\
(0.014)\end{array}$ & 0.006 \\
\hline
\end{tabular}

Number of students who applied $\quad 589 \quad 1,306$

Source: Michigan administrative data and University of Michigan Office of Enrollment Management data.

Notes: Standard errors in parentheses. P-value is from a two-way t-test with unequal variances. For reference, the overall UM acceptance rate in $2016-17$ was 28.6 percent. 
Appendix Table VI

Randomization-Based Inference on College Choice Outcomes

First and Second HAIL Cohorts

\begin{tabular}{|c|c|c|c|c|c|c|c|c|}
\hline \multirow[b]{2}{*}{ College Attended } & \multirow[b]{2}{*}{$\begin{array}{c}\text { Estimated } \\
\text { treatment } \\
\text { effect }\end{array}$} & \multicolumn{5}{|c|}{ Simulated treatment effects $(10,000$ iterations $)$} & \multirow[b]{2}{*}{$\begin{array}{c}\text { Randomiz.- } \\
\text { based } \\
\text { p-value }\end{array}$} & \multirow[b]{2}{*}{$\begin{array}{c}\text { Sampling } \\
\text { based } \\
\text { p-value }\end{array}$} \\
\hline & & Mean & Std. Dev. & Min & Max & $\begin{array}{l}\text { \# greater } \\
\text { than estim. } \\
\text { effect }\end{array}$ & & \\
\hline Highly competitive or above & 0.146 & 0.000 & 0.020 & -0.077 & 0.075 & 0 & 0.000 & 0.000 \\
\hline UM & 0.146 & 0.000 & 0.019 & -0.064 & 0.083 & 0 & 0.000 & 0.000 \\
\hline Highly competitive or above other than UM & 0.000 & 0.000 & 0.007 & -0.023 & 0.024 & 9,809 & 0.981 & 0.981 \\
\hline Four-year & 0.074 & 0.000 & 0.022 & -0.082 & 0.081 & 11 & 0.001 & 0.000 \\
\hline Two-year & -0.035 & 0.000 & 0.014 & -0.051 & 0.053 & 112 & 0.011 & 0.007 \\
\hline Any & 0.039 & 0.000 & 0.019 & -0.079 & 0.064 & 385 & 0.039 & 0.031 \\
\hline In Michigan & 0.045 & 0.000 & 0.020 & -0.084 & 0.084 & 265 & 0.027 & 0.021 \\
\hline Public in Michigan & 0.062 & 0.000 & 0.021 & -0.085 & 0.086 & 30 & 0.003 & 0.003 \\
\hline Outside Michigan & -0.006 & 0.000 & 0.010 & -0.036 & 0.036 & 5,432 & 0.543 & 0.531 \\
\hline
\end{tabular}

Source: Michigan administrative data and National Student Clearinghouse data.

Notes: Each simulated treatment effect comes from first randomly assigning schools to treatment using the same randomization algorithm used for true assignment, then running a regression of the outcome on "treatment" status, including controls for strata. Exact p-value is calculated as the number of simulated effects greater in absolute value than the estimated effect. 


\section{Appendix Table VII}

Estimated Effect of HAIL Scholarship on UM Application, Admission, and Enrollment by High School Geography, With and Without Covariates

First and Second HAIL Cohorts

\begin{tabular}{|c|c|c|c|c|c|c|}
\hline \multicolumn{7}{|c|}{ Panel A. Region } \\
\hline \multirow[b]{2}{*}{ Applied } & \multicolumn{2}{|c|}{ Southeast } & \multicolumn{2}{|c|}{ West Central } & \multicolumn{2}{|c|}{ Upper Peninsula } \\
\hline & $\begin{array}{c}0.378 \\
(0.031) \\
{[0.364]}\end{array}$ & $\begin{array}{c}0.370 \\
(0.030)\end{array}$ & $\begin{array}{c}0.466 \\
(0.029) \\
{[0.2]}\end{array}$ & $\begin{array}{c}0.466 \\
(0.027)\end{array}$ & $\begin{array}{c}0.398 \\
(0.059) \\
{[0.156]}\end{array}$ & $\begin{array}{l}0.415 \\
(0.056)\end{array}$ \\
\hline Admitted & $\begin{array}{c}0.159 \\
(0.031) \\
{[0.202]}\end{array}$ & $\begin{array}{l}0.130 \\
(0.027)\end{array}$ & $\begin{array}{l}0.187 \\
(0.026) \\
{[0.116]}\end{array}$ & $\begin{array}{c}0.177 \\
(0.024)\end{array}$ & $\begin{array}{c}0.187 \\
(0.054) \\
{[0.105]}\end{array}$ & $\begin{array}{l}0.215 \\
(0.050)\end{array}$ \\
\hline Enrolled & $\begin{array}{c}0.145 \\
(0.029) \\
{[0.167]}\end{array}$ & $\begin{array}{c}0.122 \\
(0.026)\end{array}$ & $\begin{array}{c}0.152 \\
(0.024) \\
{[0.085]}\end{array}$ & $\begin{array}{c}0.146 \\
(0.023)\end{array}$ & $\begin{array}{c}0.176 \\
(0.051) \\
{[0.08]}\end{array}$ & $\begin{array}{l}0.198 \\
(0.049)\end{array}$ \\
\hline $\begin{array}{l}\text { Covariates } \\
\text { Number of schools } \\
\text { Number of students }\end{array}$ & \multicolumn{2}{|c|}{$\begin{array}{l}408 \\
1848\end{array}$} & \multicolumn{2}{|c|}{$\begin{array}{c}474 \\
1646\end{array}$} & $\begin{array}{l}\mathrm{N} \\
\\
\\
\\
\end{array}$ & $\begin{array}{ll} & Y \\
4 & \\
6 & \end{array}$ \\
\hline \multicolumn{7}{|c|}{ Panel B. Urbanicity } \\
\hline & \multicolumn{2}{|c|}{ Suburb } & \multicolumn{2}{|c|}{ City } & \multicolumn{2}{|c|}{ Town/Rural } \\
\hline Applied & $\begin{array}{c}0.384 \\
(0.031) \\
{[0.336]}\end{array}$ & $\begin{array}{c}0.369 \\
(0.030)\end{array}$ & $\begin{array}{c}0.318 \\
(0.062) \\
{[0.464]}\end{array}$ & $\begin{array}{c}0.310 \\
(0.056)\end{array}$ & $\begin{array}{c}0.487 \\
(0.028) \\
{[0.159]}\end{array}$ & $\begin{array}{l}0.487 \\
(0.027)\end{array}$ \\
\hline Admitted & $\begin{array}{c}0.156 \\
(0.029) \\
{[0.164]}\end{array}$ & $\begin{array}{c}0.119 \\
(0.025)\end{array}$ & $\begin{array}{c}0.061 \\
(0.066) \\
{[0.319]}\end{array}$ & $\begin{array}{c}0.006 \\
(0.056)\end{array}$ & $\begin{array}{c}0.228 \\
(0.026) \\
{[0.097]}\end{array}$ & $\begin{array}{l}0.223 \\
(0.023)\end{array}$ \\
\hline Enrolled & $\begin{array}{c}0.133 \\
(0.027) \\
{[0.14]}\end{array}$ & $\begin{array}{l}0.101 \\
(0.024)\end{array}$ & $\begin{array}{c}0.117 \\
(0.061) \\
{[0.221]}\end{array}$ & $\begin{array}{c}0.083 \\
(0.050)\end{array}$ & $\begin{array}{c}0.183 \\
(0.024) \\
{[0.078]}\end{array}$ & $\begin{array}{l}0.183 \\
(0.023)\end{array}$ \\
\hline Covariates & $\mathrm{N}$ & Y & $\mathrm{N}$ & $\mathrm{Y}$ & $\mathrm{N}$ & Y \\
\hline $\begin{array}{l}\text { Number of schools } \\
\text { Number of students }\end{array}$ & 17 & & & & & \\
\hline
\end{tabular}

Source: Michigan administrative data and University of Michigan Office of Enrollment Management data.

Notes: All analyses done at the school-year level. Coefficients are from separate regressions of outcome on treatment status and strata dummies, estimated on the subgroup. Covariates include all characteristics listed in Appendix Table II. Robust standard errors reported in parentheses. Control mean for subgroup in brackets. Application, admission and enrollment measured in the summer and fall following expected high school graduation. Admission and enrollment are unconditional on application. 


\section{Appendix Table VIII}

Estimated Effect of HAIL Scholarship on UM Application, Admission, and Enrollment by Historical School Connection to UM and Number of HAIL Students (First and Second HAIL Cohorts):

Regression Results

\begin{tabular}{lccc}
\hline \multirow{2}{*}{ Panel A. Prior School-Level UM } & Application & Rate \\
\cline { 2 - 4 } & 0.489 & 0.203 & 0.170 \\
\hline \hline Treatment & $(0.025)$ & $(0.024)$ & $(0.023)$ \\
Prior UM application rate & 1.226 & 0.741 & 0.643 \\
& $(0.177)$ & $(0.179)$ & $(0.174)$ \\
Interaction & -0.984 & -0.341 & -0.225 \\
& $(0.219)$ & $(0.238)$ & $(0.240)$
\end{tabular}

Panel B. Prior School-Level UM Enrollment Rate

\begin{tabular}{lccc}
\hline \hline Treatment & 0.486 & 0.201 & 0.171 \\
& $(0.024)$ & $(0.023)$ & $(0.021)$ \\
Prior UM enrollment rate & 2.843 & 1.725 & 1.531 \\
& $(0.356)$ & $(0.412)$ & $(0.406)$ \\
Interaction & -2.690 & -0.872 & -0.691 \\
& $(0.549)$ & $(0.575)$ & $(0.579)$
\end{tabular}

Panel C. Number of HAIL Students in School

\begin{tabular}{lccc}
\hline \hline Treatment & 0.485 & 0.210 & 0.184 \\
& $(0.033)$ & $(0.032)$ & $(0.030)$ \\
Number of HAIL students & 0.019 & 0.012 & 0.010 \\
& $(0.004)$ & $(0.003)$ & $(0.003)$ \\
Interaction & -0.017 & -0.009 & -0.009 \\
& $(0.005)$ & $(0.004)$ & $(0.004)$ \\
Number of school-years & & & \\
\hline
\end{tabular}

Source: Michigan administrative data and University of Michigan Office of Enrollment Management data.

Notes: All analyses done at the school-year level. Results are from a regression of the outcome on treatment, the named variable and a missing dummy, the interaction of the two, and strata dummies. Robust standard errors estimated. Prior UM application and enrollment rates are for the high school graduating class of 2015 . 


\section{Appendix Table IX}

Estimated Effect of HAIL Scholarship on UM Application, Admission, and Enrollment by Pre-Treatment Interest in UM, With and Without Covariates

First and Second HAIL Cohorts

\begin{tabular}{|c|c|c|c|c|}
\hline \multirow[b]{3}{*}{ Applied } & \multicolumn{4}{|c|}{ Pre-Treatment Interest in UM } \\
\hline & \multicolumn{2}{|c|}{ Sent SAT Scores to UM } & \multicolumn{2}{|c|}{ Did Not Send Scores } \\
\hline & $\begin{array}{c}0.372 \\
(0.029) \\
{[0.421]}\end{array}$ & $\begin{array}{c}0.368 \\
(0.028)\end{array}$ & $\begin{array}{c}0.437 \\
(0.023) \\
{[0.161]}\end{array}$ & $\begin{array}{c}0.436 \\
(0.022)\end{array}$ \\
\hline Admitted & $\begin{array}{c}0.169 \\
(0.030) \\
{[0.255]}\end{array}$ & $\begin{array}{c}0.156 \\
(0.027)\end{array}$ & $\begin{array}{c}0.165 \\
(0.019) \\
{[0.081]}\end{array}$ & $\begin{array}{c}0.159 \\
(0.018)\end{array}$ \\
\hline Enrolled & $\begin{array}{c}0.157 \\
(0.028) \\
{[0.199]}\end{array}$ & $\begin{array}{c}0.149 \\
(0.026)\end{array}$ & $\begin{array}{c}0.140 \\
(0.018) \\
{[0.059]}\end{array}$ & $\begin{array}{c}0.134 \\
(0.017)\end{array}$ \\
\hline $\begin{array}{l}\text { Covariates } \\
\text { Number of school-years } \\
\text { Number of students }\end{array}$ & $\mathrm{N}$ & $\begin{array}{ll} & Y \\
3 & \\
14 & \end{array}$ & $\mathrm{~N}$ & $\begin{array}{ll} & Y \\
2 & \\
96 & \end{array}$ \\
\hline
\end{tabular}

Source: Michigan administrative data and University of Michigan Office of Enrollment Management data.

Notes: All analyses done at the school-year level. Coefficients are from separate regressions of school-subgroup-level outcome rate on treatment status and strata dummies. Covariates include all characteristics listed in Appendix Table II and are at the school-subgroup level. Robust standard errors reported in parentheses. Control mean for subgroup in brackets. UM application, admission and enrollment measured in the summer and fall following expected high school graduation. Admission and enrollment are unconditional on application. 


\section{Appendix Table X}

Estimated Effect of HAIL Scholarship on UM Application, Admission, and Enrollment by Economic Status, With and Without Covariates

First and Second HAIL Cohorts

\begin{tabular}{|c|c|c|c|c|}
\hline \multirow[b]{3}{*}{ Applied } & \multicolumn{4}{|c|}{ Panel A. Free or Reduced Price Lunch Eligibility } \\
\hline & \multicolumn{2}{|c|}{ Free Lunch } & \multicolumn{2}{|c|}{ Reduced-Price Lunch } \\
\hline & $\begin{array}{c}0.419 \\
(0.023) \\
{[0.27]}\end{array}$ & $\begin{array}{c}0.418 \\
(0.021)\end{array}$ & $\begin{array}{c}0.414 \\
(0.032) \\
{[0.245]}\end{array}$ & $\begin{array}{c}0.412 \\
(0.030)\end{array}$ \\
\hline Admitted & $\begin{array}{c}0.170 \\
(0.021) \\
{[0.27]}\end{array}$ & $\begin{array}{c}0.160 \\
(0.019)\end{array}$ & $\begin{array}{c}0.142 \\
(0.029) \\
{[0.146]}\end{array}$ & $\begin{array}{c}0.135 \\
(0.026)\end{array}$ \\
\hline Enrolled & $\begin{array}{c}0.146 \\
(0.020) \\
{[0.116]}\end{array}$ & $\begin{array}{c}0.138 \\
(0.018)\end{array}$ & $\begin{array}{c}0.112 \\
(0.026) \\
{[0.118]}\end{array}$ & $\begin{array}{c}0.109 \\
(0.024)\end{array}$ \\
\hline $\begin{array}{l}\text { Covariates } \\
\text { Number of school-years } \\
\text { Number of students }\end{array}$ & $\mathrm{N}$ & $\begin{array}{ll} & Y \\
3 & \\
48 & \end{array}$ & $\mathrm{~N}$ & $\begin{array}{l} \\
7 \\
62\end{array}$ \\
\hline
\end{tabular}

\begin{tabular}{|c|c|c|c|c|}
\hline \multirow[b]{3}{*}{ Applied } & \multicolumn{4}{|c|}{ Panel B. Persistence of Economic Disadvantage } \\
\hline & \multicolumn{2}{|c|}{ Always Disadvantaged } & \multicolumn{2}{|c|}{ Sometimes Disadvantaged } \\
\hline & $\begin{array}{c}0.423 \\
(0.022) \\
{[0.259]}\end{array}$ & $\begin{array}{c}0.420 \\
(0.021)\end{array}$ & $\begin{array}{c}0.402 \\
(0.041) \\
{[0.302]}\end{array}$ & $\begin{array}{c}0.399 \\
(0.038)\end{array}$ \\
\hline Admitted & $\begin{array}{c}0.177 \\
(0.020) \\
{[0.149]}\end{array}$ & $\begin{array}{c}0.170 \\
(0.018)\end{array}$ & $\begin{array}{c}0.152 \\
(0.037) \\
{[0.167]}\end{array}$ & $\begin{array}{c}0.125 \\
(0.032)\end{array}$ \\
\hline Enrolled & $\begin{array}{c}0.153 \\
(0.019) \\
{[0.118]}\end{array}$ & $\begin{array}{c}0.148 \\
(0.017)\end{array}$ & $\begin{array}{c}0.140 \\
(0.035) \\
{[0.13]}\end{array}$ & $\begin{array}{c}0.116 \\
(0.032)\end{array}$ \\
\hline $\begin{array}{l}\text { Covariates } \\
\text { Number of school-years } \\
\text { Number of students }\end{array}$ & $\mathrm{N}$ & $\begin{array}{ll} & Y \\
2 & \\
68 & \end{array}$ & $\mathrm{~N}$ & $\begin{array}{ll} & \mathrm{Y} \\
25 & \\
42 & \end{array}$ \\
\hline
\end{tabular}

Source: Michigan administrative data and University of Michigan Office of Enrollment Management data.

Notes: All analyses done at the school-year level. Coefficients are from separate regressions of school-subgroup-level outcome rate on treatment status and strata dummies. Covariates include all characteristics listed in Appendix Table II and are at the school-subgroup level. Robust standard errors reported in parentheses. Control mean for subgroup in brackets. UM application, admission and enrollment measured in the summer and fall following expected high school graduation. Admission and enrollment are unconditional on application. In Panel A, eligibility is measured in 11th grade. In Panel B, "always disadvantaged" is defined as being eligible for free or reduced-price lunch every (observed) year of high school through 11th grade. 


\section{Appendix Table XI}

Estimated Effect of HAIL Scholarship on UM Application, Admission, and Enrollment by Selected Student Characteristics, With and Without Covariates

First and Second HAIL Cohorts

\begin{tabular}{|c|c|c|c|c|c|c|}
\hline \multicolumn{7}{|c|}{ Panel A. Gender } \\
\hline \multirow[b]{2}{*}{ Applied } & \multicolumn{2}{|c|}{ Male } & \multicolumn{2}{|c|}{ Female } & & \\
\hline & $\begin{array}{c}0.406 \\
(0.028) \\
{[0.286]}\end{array}$ & $\begin{array}{c}0.402 \\
(0.026)\end{array}$ & $\begin{array}{c}0.422 \\
(0.024) \\
{[0.239]}\end{array}$ & $\begin{array}{c}0.419 \\
(0.023)\end{array}$ & & \\
\hline Admitted & $\begin{array}{c}0.141 \\
(0.024) \\
{[0.139]}\end{array}$ & $\begin{array}{c}0.135 \\
(0.022)\end{array}$ & $\begin{array}{c}0.188 \\
(0.022) \\
{[0.143]}\end{array}$ & $\begin{array}{c}0.185 \\
(0.020)\end{array}$ & & \\
\hline Enrolled & $\begin{array}{c}0.118 \\
(0.022) \\
{[0.105]}\end{array}$ & $\begin{array}{c}0.113 \\
(0.021)\end{array}$ & $\begin{array}{c}0.164 \\
(0.021) \\
{[0.115]}\end{array}$ & $\begin{array}{c}0.164 \\
(0.020)\end{array}$ & & \\
\hline $\begin{array}{l}\text { Covariates } \\
\text { Number of schools } \\
\text { Number of students }\end{array}$ & \multicolumn{2}{|c|}{$\begin{array}{c}729 \\
1,637\end{array}$} & \multicolumn{2}{|c|}{$\begin{array}{c}855 \\
2,273\end{array}$} & & \\
\hline \multicolumn{7}{|c|}{ Panel B. Race/Ethnicity } \\
\hline & \multicolumn{2}{|c|}{ White or Asian } & \multicolumn{2}{|c|}{ Black } & \multicolumn{2}{|c|}{ Other } \\
\hline Applied & $\begin{array}{c}0.438 \\
(0.022) \\
{[0.234]}\end{array}$ & $\begin{array}{c}0.437 \\
(0.021)\end{array}$ & $\begin{array}{c}0.262 \\
(0.060) \\
{[0.478]}\end{array}$ & $\begin{array}{c}0.303 \\
(0.061)\end{array}$ & $\begin{array}{c}0.242 \\
(0.068) \\
{[0.393]}\end{array}$ & $\begin{array}{c}0.259 \\
(0.064)\end{array}$ \\
\hline Admitted & $\begin{array}{c}0.182 \\
(0.019) \\
{[0.129]}\end{array}$ & $\begin{array}{c}0.173 \\
(0.017)\end{array}$ & $\begin{array}{c}0.072 \\
(0.059) \\
{[0.283]}\end{array}$ & $\begin{array}{c}0.102 \\
(0.056)\end{array}$ & $\begin{array}{c}0.043 \\
(0.062) \\
{[0.258]}\end{array}$ & $\begin{array}{c}0.053 \\
(0.063)\end{array}$ \\
\hline Enrolled & $\begin{array}{c}0.154 \\
(0.018) \\
{[0.103]}\end{array}$ & $\begin{array}{c}0.148 \\
(0.016)\end{array}$ & $\begin{array}{c}0.037 \\
(0.055) \\
{[0.234]}\end{array}$ & $\begin{array}{c}0.048 \\
(0.052)\end{array}$ & $\begin{array}{c}0.072 \\
(0.058) \\
{[0.199]}\end{array}$ & $\begin{array}{c}0.083 \\
(0.060)\end{array}$ \\
\hline $\begin{array}{l}\text { Covariates } \\
\text { Number of schools }\end{array}$ & $\begin{array}{l}\mathrm{N} \\
9\end{array}$ & $8^{\mathrm{Y}}$ & $\mathrm{N}_{2}$ & $6^{Y}$ & $\mathrm{~N}$ & $1 \quad \mathrm{Y}$ \\
\hline
\end{tabular}

Source: Michigan administrative data and University of Michigan Office of Enrollment Management data.

Notes: All analyses done at the school-year level. Coefficients are from separate regressions of school-subgroup-level outcome rate on treatment status and strata dummies. Covariates include all characteristics listed in Appendix Table II and are at the school-subgroup level. Robust standard errors reported in parentheses. Control mean for subgroup in brackets. UM application, admission and enrollment measured in the summer and fall following expected high school graduation. Admission and enrollment are unconditional on application. 


\section{Appendix Table XII}

Coefficients from Regression Used to Predict Selective College Attendance

\begin{tabular}{lc}
\hline Outcome: Enrolled at highly competitive or above college \\
\hline \hline ACT score & 0.034 \\
GPA & $(0.002)$ \\
& 0.354 \\
Black & $(0.026)$ \\
& 0.174 \\
Other race/ethnicity & $(0.019)$ \\
& 0.086 \\
Female & $(0.020)$ \\
& -0.007 \\
Always economically disadvantaged & $(0.010)$ \\
& 0.008 \\
High school in city & $(0.012)$ \\
& 0.035 \\
High school in town or rural area & $(0.014)$ \\
& -0.023 \\
High school in Upper Peninsula & $(0.013)$ \\
& -0.050 \\
High school in West Central Michigan & $(0.018)$ \\
\# of HAIL students in school & -0.031 \\
UM application rate in 2015 & $(0.012)$ \\
& -0.001 \\
N & $(0.001)$ \\
& 1.345 \\
& $(0.131)$ \\
& \\
& 4,529 \\
& 0.152 \\
\hline
\end{tabular}

Source: Michigan administrative data, University of Michigan Office of Enrollment Management data, and National Student Clearinghouse data.

Notes: Coefficients and standard errors from a regression of highly selective college attendance on all of the listed characteristics, estimated on the population of high-achieving, low-income students in Michigan who were in 11th grade during the 2012-13 and 2013-14 school years. Sample criteria are the same as for HAIL scholarship students in the subsequent year. College attendance is measured at the first college attended in the fall following expected high school graduation and is unconditional on any college enrollment. Selectivity is based on Barron's selectivity index. 


\section{Appendix Table XIII}

Estimated Effect of HAIL Scholarship on College Choice, With and Without Covariates First and Second HAIL Cohorts

\begin{tabular}{|c|c|c|c|}
\hline College attended & \multicolumn{2}{|c|}{ Treatment effect } & Control mean \\
\hline Highly competitive or above & $\begin{array}{c}0.146 \\
(0.018)\end{array}$ & $\begin{array}{c}0.141 \\
(0.017)\end{array}$ & 0.135 \\
\hline UM & $\begin{array}{c}0.146 \\
(0.016)\end{array}$ & $\begin{array}{c}0.139 \\
(0.016)\end{array}$ & 0.107 \\
\hline $\begin{array}{l}\text { Highly competitive or above } \\
\text { other than UM }\end{array}$ & $\begin{array}{c}0.000 \\
(0.007)\end{array}$ & $\begin{array}{c}0.002 \\
(0.007)\end{array}$ & 0.028 \\
\hline Four-year & $\begin{array}{c}0.074 \\
(0.020)\end{array}$ & $\begin{array}{c}0.080 \\
(0.020)\end{array}$ & 0.675 \\
\hline Two-year & $\begin{array}{l}-0.035 \\
(0.013)\end{array}$ & $\begin{array}{l}-0.036 \\
(0.013)\end{array}$ & 0.116 \\
\hline Any & $\begin{array}{c}0.039 \\
(0.018)\end{array}$ & $\begin{array}{c}0.045 \\
(0.018)\end{array}$ & 0.791 \\
\hline In Michigan & $\begin{array}{c}0.045 \\
(0.020)\end{array}$ & $\begin{array}{c}0.047 \\
(0.020)\end{array}$ & 0.727 \\
\hline Public in Michigan & $\begin{array}{c}0.062 \\
(0.021)\end{array}$ & $\begin{array}{c}0.064 \\
(0.021)\end{array}$ & 0.645 \\
\hline Outside Michigan & $\begin{array}{l}-0.006 \\
(0.010)\end{array}$ & $\begin{array}{l}-0.003 \\
(0.010)\end{array}$ & 0.064 \\
\hline $\begin{array}{l}\text { Covariates } \\
\text { Number of school-years } \\
\text { Number of students }\end{array}$ & $\mathrm{N}$ & $\begin{array}{l}\mathrm{Y} \\
1,02 \\
3,910\end{array}$ & \\
\hline
\end{tabular}

Source: Michigan administrative data and National Student Clearinghouse data.

Notes: All analyses done at the school-year level. Coefficients are from regressions of outcome on treatment status and strata dummies. Covariates include all characteristics listed in Appendix Table II. Robust standard errors reported. Enrollment is measured at the first college attended in the fall following expected high school graduation and is unconditional on any college enrollment. 


\section{Appendix Table XIV}

Estimated Effect of HAIL Scholarship on College Choice by Selected School and Student Characteristics, With and Without Covariates

First and Second HAIL Cohorts

\begin{tabular}{|c|c|c|c|c|c|c|}
\hline \multicolumn{7}{|c|}{ Panel A. Region } \\
\hline & \multicolumn{2}{|c|}{ Southeast } & \multicolumn{2}{|c|}{ West Central } & \multicolumn{2}{|c|}{ Upper Peninsula } \\
\hline Highly competitive or above & $\begin{array}{l}0.129 \\
(0.030) \\
{[0.199]}\end{array}$ & $\begin{array}{c}0.108 \\
(0.028)\end{array}$ & $\begin{array}{c}0.163 \\
(0.024) \\
{[0.092]}\end{array}$ & $\begin{array}{c}0.156 \\
(0.022)\end{array}$ & $\begin{array}{c}0.160 \\
(0.052) \\
{[0.091]}\end{array}$ & $\begin{array}{c}0.180 \\
(0.052)\end{array}$ \\
\hline UM & $\begin{array}{l}0.133 \\
(0.029) \\
{[0.162]}\end{array}$ & $\begin{array}{c}0.108 \\
(0.027)\end{array}$ & $\begin{array}{c}0.155 \\
(0.022) \\
{[0.068]}\end{array}$ & $\begin{array}{c}0.148 \\
(0.022)\end{array}$ & $\begin{array}{c}0.167 \\
(0.052) \\
{[0.078]}\end{array}$ & $\begin{array}{c}0.191 \\
(0.050)\end{array}$ \\
\hline Four-year & $\begin{array}{c}0.041 \\
(0.029) \\
{[0.774]}\end{array}$ & $\begin{array}{c}0.045 \\
(0.030)\end{array}$ & $\begin{array}{c}0.114 \\
(0.031) \\
{[0.579]}\end{array}$ & $\begin{array}{c}0.120 \\
(0.031)\end{array}$ & $\begin{array}{c}0.037 \\
(0.060) \\
{[0.697]}\end{array}$ & $\begin{array}{c}0.049 \\
(0.062)\end{array}$ \\
\hline Any & $\begin{array}{c}0.024 \\
(0.026) \\
{[0.84]}\end{array}$ & $\begin{array}{c}0.022 \\
(0.027)\end{array}$ & $\begin{array}{c}0.045 \\
(0.027) \\
{[0.758]}\end{array}$ & $\begin{array}{c}0.056 \\
(0.028)\end{array}$ & $\begin{array}{c}0.061 \\
(0.055) \\
{[0.757]}\end{array}$ & $\begin{array}{c}0.069 \\
(0.057)\end{array}$ \\
\hline $\begin{array}{l}\text { Covariates } \\
\text { Number of school-years } \\
\text { Number of students }\end{array}$ & $\begin{array}{l}\mathrm{N} \\
4 \\
1,\end{array}$ & $\begin{array}{ll} & Y \\
8 & \\
48 & \end{array}$ & $\begin{array}{l}\mathrm{N} \\
4 \\
1,6\end{array}$ & $\begin{array}{ll} & Y \\
4 & \\
46 & \end{array}$ & $\begin{array}{l}\mathrm{N} \\
1 \\
4\end{array}$ & $\begin{array}{ll} & Y \\
4 & \\
6 & \end{array}$ \\
\hline \multicolumn{7}{|c|}{ Panel B. Urbanicity } \\
\hline & \multicolumn{2}{|c|}{ Suburb } & \multicolumn{2}{|c|}{ City } & \multicolumn{2}{|c|}{ Town or Rural } \\
\hline Highly competitive or above & $\begin{array}{l}0.136 \\
(0.029) \\
{[0.163]}\end{array}$ & $\begin{array}{c}0.100 \\
(0.025)\end{array}$ & $\begin{array}{c}0.079 \\
(0.063) \\
{[0.249]}\end{array}$ & $\begin{array}{c}0.072 \\
(0.059)\end{array}$ & $\begin{array}{c}0.181 \\
(0.024) \\
{[0.088]}\end{array}$ & $\begin{array}{c}0.184 \\
(0.022)\end{array}$ \\
\hline UM & $\begin{array}{l}0.126 \\
(0.027) \\
{[0.139]}\end{array}$ & $\begin{array}{c}0.095 \\
(0.025)\end{array}$ & $\begin{array}{c}0.078 \\
(0.058) \\
{[0.203]}\end{array}$ & $\begin{array}{c}0.052 \\
(0.052)\end{array}$ & $\begin{array}{c}0.187 \\
(0.023) \\
{[0.063]}\end{array}$ & $\begin{array}{c}0.188 \\
(0.022)\end{array}$ \\
\hline Four-year & $\begin{array}{c}0.039 \\
(0.030) \\
{[0.746]}\end{array}$ & $\begin{array}{c}0.034 \\
(0.029)\end{array}$ & $\begin{array}{c}0.007 \\
(0.064) \\
{[0.704]}\end{array}$ & $\begin{array}{c}0.029 \\
(0.069)\end{array}$ & $\begin{array}{c}0.103 \\
(0.030) \\
{[0.622]}\end{array}$ & $\begin{array}{c}0.115 \\
(0.030)\end{array}$ \\
\hline Any & $\begin{array}{c}0.014 \\
(0.027) \\
{[0.838]}\end{array}$ & $\begin{array}{c}0.013 \\
(0.027)\end{array}$ & $\begin{array}{c}0.018 \\
(0.056) \\
{[0.783]}\end{array}$ & $\begin{array}{c}0.049 \\
(0.064)\end{array}$ & $\begin{array}{c}0.053 \\
(0.026) \\
{[0.762]}\end{array}$ & $\begin{array}{c}0.064 \\
(0.026)\end{array}$ \\
\hline Covariates & $\mathrm{N}$ & $\mathrm{Y}$ & $\mathrm{N}$ & $\mathrm{Y}$ & $\mathrm{N}$ & $\mathrm{Y}$ \\
\hline $\begin{array}{l}\text { Number of school-years } \\
\text { Number of students }\end{array}$ & $\begin{array}{c}3 \\
1,\end{array}$ & & & & 1 , & \\
\hline
\end{tabular}


Appendix Table XIV (Continued)

Estimated Effect of HAIL Scholarship on College Choice by Selected School and Student Characteristics,

With and Without Covariates

First and Second HAIL Cohorts

\begin{tabular}{|c|c|c|c|c|c|c|}
\hline \multicolumn{7}{|c|}{ Panel C. Gender } \\
\hline & \multicolumn{2}{|c|}{ Male } & \multicolumn{2}{|c|}{ Female } & & \\
\hline Highly competitive or above & $\begin{array}{c}0.110 \\
(0.023) \\
{[0.135]}\end{array}$ & $\begin{array}{c}0.107 \\
(0.022)\end{array}$ & $\begin{array}{c}0.167 \\
(0.021) \\
{[0.125]}\end{array}$ & $\begin{array}{c}0.167 \\
(0.020)\end{array}$ & & \\
\hline UM & $\begin{array}{c}0.112 \\
(0.022) \\
{[0.1]}\end{array}$ & $\begin{array}{c}0.108 \\
(0.020)\end{array}$ & $\begin{array}{c}0.161 \\
(0.020) \\
{[0.104]}\end{array}$ & $\begin{array}{c}0.161 \\
(0.019)\end{array}$ & & \\
\hline Four-year & $\begin{array}{c}0.073 \\
(0.027) \\
{[0.672]}\end{array}$ & $\begin{array}{c}0.072 \\
(0.027)\end{array}$ & $\begin{array}{c}0.086 \\
(0.025) \\
{[0.671]}\end{array}$ & $\begin{array}{c}0.087 \\
(0.024)\end{array}$ & & \\
\hline Any & $\begin{array}{c}0.029 \\
(0.023) \\
{[0.798]}\end{array}$ & $\begin{array}{c}0.029 \\
(0.023)\end{array}$ & $\begin{array}{c}0.055 \\
(0.021) \\
{[0.793]}\end{array}$ & $\begin{array}{c}0.059 \\
(0.021)\end{array}$ & & \\
\hline Covariates & $\mathrm{N}$ & $\mathrm{Y}$ & $\mathrm{N}$ & $\mathrm{Y}$ & & \\
\hline Number of school-years & \multirow{2}{*}{\multicolumn{2}{|c|}{$\begin{array}{c}729 \\
1.637\end{array}$}} & \multirow{2}{*}{\multicolumn{2}{|c|}{$\begin{array}{c}855 \\
2,273\end{array}$}} & & \\
\hline Number of students & & & & & & \\
\hline \multicolumn{7}{|c|}{ Panel D. Race/Ethnicity } \\
\hline & \multicolumn{2}{|c|}{ White or Asian } & \multicolumn{2}{|c|}{ Black } & \multicolumn{2}{|c|}{ Other } \\
\hline Highly competitive or above & $\begin{array}{c}0.151 \\
(0.018) \\
{[0.119]}\end{array}$ & $\begin{array}{c}0.147 \\
(0.017)\end{array}$ & $\begin{array}{c}0.061 \\
(0.057) \\
{[0.272]}\end{array}$ & $\begin{array}{c}0.060 \\
(0.052)\end{array}$ & $\begin{array}{c}0.082 \\
(0.057) \\
{[0.179]}\end{array}$ & $\begin{array}{c}0.099 \\
(0.059)\end{array}$ \\
\hline UM & $\begin{array}{c}0.150 \\
(0.017) \\
{[0.096]}\end{array}$ & $\begin{array}{c}0.145 \\
(0.016)\end{array}$ & $\begin{array}{c}0.018 \\
(0.052) \\
{[0.214]}\end{array}$ & $\begin{array}{c}0.020 \\
(0.049)\end{array}$ & $\begin{array}{c}0.079 \\
(0.056) \\
{[0.167]}\end{array}$ & $\begin{array}{c}0.097 \\
(0.058)\end{array}$ \\
\hline Four-year & $\begin{array}{c}0.072 \\
(0.022) \\
{[0.675]}\end{array}$ & $\begin{array}{c}0.078 \\
(0.021)\end{array}$ & $\begin{array}{l}-0.041 \\
(0.055) \\
{[0.792]}\end{array}$ & $\begin{array}{c}-0.050 \\
(0.055)\end{array}$ & $\begin{array}{c}0.167 \\
(0.064) \\
{[0.593]}\end{array}$ & $\begin{array}{c}0.187 \\
(0.063)\end{array}$ \\
\hline Any & $\begin{array}{c}0.031 \\
(0.018) \\
{[0.801]}\end{array}$ & $\begin{array}{c}0.036 \\
(0.018)\end{array}$ & $\begin{array}{l}-0.062 \\
(0.049) \\
{[0.848]}\end{array}$ & $\begin{array}{c}-0.077 \\
(0.049)\end{array}$ & $\begin{array}{c}0.121 \\
(0.055) \\
{[0.716]}\end{array}$ & $\begin{array}{c}0.146 \\
(0.054)\end{array}$ \\
\hline Covariates & $\mathrm{N}$ & $\mathrm{Y}$ & $\mathrm{N}$ & $\mathrm{Y}$ & $\mathrm{N}$ & $\mathrm{Y}$ \\
\hline $\begin{array}{l}\text { Number of school-years } \\
\text { Number of students }\end{array}$ & $\begin{array}{c}9 \\
3,\end{array}$ & $\begin{array}{l}8 \\
12\end{array}$ & & & & \\
\hline
\end{tabular}

Source: Michigan administrative data and National Student Clearinghouse data.

Notes: All analyses done at the school-year level. For Panels A and B, coefficients are from separate regressions of outcome on treatment status and strata dummies, estimated on the subgroup. For Panels $\mathrm{C}$ and D, coefficients are from separate regressions of school-subgroup-level outcome rate on treatment status and strata dummies. Covariates include all characteristics listed in Appendix Table II and are at the school-subgroup level. Robust standard errors reported in parentheses. Control mean for subgroup in brackets. Enrollment is measured at the first college attended in the fall following expected high school graduation and is unconditional on any college enrollment. 


Appendix Table XV Estimated Effect of HAIL Scholarship on College Enrollment and Persistence, With
and Without Covariates
First HAIL Cohort

Source: Michigan administrative data and National Student Clearinghouse data.

Notes: All analyses done at the school-year level. Coefficients are from regressions of outcome on treatment status and strata dummies. Covariates include all characteristics listed in Appendix Table II. Robust standard errors reported. Enrollment is measured at the first college attended in the two falls following expected high school graduation and is unconditional on any college enrollment. 


\section{Appendix Table XVI}

Estimated Effect of HAIL Scholarship on Second Year College Persistence by Selected School and Student Characteristics, With and Without Covariates First HAIL Cohort

\begin{tabular}{|c|c|c|c|c|c|c|}
\hline \multicolumn{7}{|c|}{ Panel A. Region } \\
\hline & \multicolumn{2}{|c|}{ Southeast } & \multicolumn{2}{|c|}{ West Central } & \multicolumn{2}{|c|}{ Upper Peninsula } \\
\hline Highly competitive or above & $\begin{array}{c}0.127 \\
(0.039) \\
{[0.183]}\end{array}$ & $\begin{array}{c}0.117 \\
(0.033)\end{array}$ & $\begin{array}{c}0.148 \\
(0.029) \\
{[0.089]}\end{array}$ & $\begin{array}{c}0.145 \\
(0.028)\end{array}$ & $\begin{array}{c}0.132 \\
(0.067) \\
{[0.091]}\end{array}$ & $\begin{array}{c}0.167 \\
(0.055)\end{array}$ \\
\hline UM & $\begin{array}{c}0.113 \\
(0.037) \\
{[0.145]}\end{array}$ & $\begin{array}{c}0.097 \\
(0.031)\end{array}$ & $\begin{array}{c}0.144 \\
(0.028) \\
{[0.07]}\end{array}$ & $\begin{array}{c}0.144 \\
(0.027)\end{array}$ & $\begin{array}{c}0.125 \\
(0.066) \\
{[0.091]}\end{array}$ & $\begin{array}{c}0.156 \\
(0.054)\end{array}$ \\
\hline Four-year & $\begin{array}{c}0.091 \\
(0.042) \\
{[0.667]}\end{array}$ & $\begin{array}{c}0.108 \\
(0.041)\end{array}$ & $\begin{array}{c}0.146 \\
(0.043) \\
{[0.462]}\end{array}$ & $\begin{array}{c}0.150 \\
(0.044)\end{array}$ & $\begin{array}{c}0.046 \\
(0.083) \\
{[0.563]}\end{array}$ & $\begin{array}{c}0.045 \\
(0.089)\end{array}$ \\
\hline Any & $\begin{array}{c}0.084 \\
(0.038) \\
{[0.746]}\end{array}$ & $\begin{array}{c}0.091 \\
(0.039)\end{array}$ & $\begin{array}{c}0.085 \\
(0.041) \\
{[0.632]}\end{array}$ & $\begin{array}{c}0.092 \\
(0.043)\end{array}$ & $\begin{array}{c}0.053 \\
(0.080) \\
{[0.676]}\end{array}$ & $\begin{array}{c}0.055 \\
(0.083)\end{array}$ \\
\hline Covariates & $\mathrm{N}$ & $\mathrm{Y}$ & $\mathrm{N}$ & $\mathrm{Y}$ & $\mathrm{N}$ & $\mathrm{Y}$ \\
\hline $\begin{array}{l}\text { Number of school-years } \\
\text { Number of students }\end{array}$ & \multicolumn{2}{|c|}{951} & \multicolumn{2}{|c|}{247} & 78 & 230 \\
\hline \multicolumn{7}{|c|}{ Panel B. Urbanicity } \\
\hline & \multicolumn{2}{|c|}{ Suburb } & \multicolumn{2}{|c|}{ City } & \multicolumn{2}{|c|}{ Town or Rural } \\
\hline Highly competitive or above & $\begin{array}{c}0.160 \\
(0.035) \\
{[0.115]}\end{array}$ & $\begin{array}{c}0.125 \\
(0.031)\end{array}$ & $\begin{array}{c}0.016 \\
(0.085) \\
{[0.267]}\end{array}$ & $\begin{array}{c}0.051 \\
(0.083)\end{array}$ & $\begin{array}{c}0.150 \\
(0.031) \\
{[0.1]}\end{array}$ & $\begin{array}{c}0.152 \\
(0.027)\end{array}$ \\
\hline UM & $\begin{array}{c}0.129 \\
(0.033) \\
{[0.096]}\end{array}$ & $\begin{array}{c}0.103 \\
(0.029)\end{array}$ & $\begin{array}{l}-0.006 \\
(0.079) \\
{[0.234]}\end{array}$ & $\begin{array}{l}-0.025 \\
(0.085)\end{array}$ & $\begin{array}{c}0.161 \\
(0.030) \\
{[0.076]}\end{array}$ & $\begin{array}{c}0.162 \\
(0.027)\end{array}$ \\
\hline Four-year & $\begin{array}{c}0.112 \\
(0.044) \\
{[0.623]}\end{array}$ & $\begin{array}{c}0.110 \\
(0.041)\end{array}$ & $\begin{array}{c}0.057 \\
(0.085) \\
{[0.646]}\end{array}$ & $\begin{array}{c}0.057 \\
(0.094)\end{array}$ & $\begin{array}{c}0.118 \\
(0.042) \\
{[0.498]}\end{array}$ & $\begin{array}{c}0.131 \\
(0.042)\end{array}$ \\
\hline Any & $\begin{array}{c}0.109 \\
(0.041) \\
{[0.722]}\end{array}$ & $\begin{array}{c}0.109 \\
(0.039)\end{array}$ & $\begin{array}{c}0.050 \\
(0.072) \\
{[0.739]}\end{array}$ & $\begin{array}{c}0.053 \\
(0.093)\end{array}$ & $\begin{array}{c}0.067 \\
(0.040) \\
{[0.648]}\end{array}$ & $\begin{array}{c}0.074 \\
(0.040)\end{array}$ \\
\hline Covariates & $\mathrm{N}$ & $\mathrm{Y}$ & $\mathrm{N}$ & $\mathrm{Y}$ & $\mathrm{N}$ & $\mathrm{Y}$ \\
\hline $\begin{array}{l}\text { Number of school-years } \\
\text { Number of students }\end{array}$ & & & & & & \\
\hline
\end{tabular}


Appendix Table XVI (Continued)

Estimated Effect of HAIL Scholarship on Second Year College Persistence by Selected School and Student Characteristics, With and Without Covariates

First HAIL Cohort

\begin{tabular}{|c|c|c|c|c|c|c|}
\hline \multicolumn{7}{|c|}{ Panel C. Gender } \\
\hline & \multicolumn{2}{|c|}{ Male } & \multicolumn{2}{|c|}{ Female } & & \\
\hline Highly competitive or above & $\begin{array}{l}0.120 \\
(0.030) \\
{[0.118]}\end{array}$ & $\begin{array}{c}0.110 \\
(0.028)\end{array}$ & $\begin{array}{c}0.150 \\
(0.028) \\
{[0.115]}\end{array}$ & $\begin{array}{c}0.156 \\
(0.025)\end{array}$ & & \\
\hline UM & $\begin{array}{l}0.119 \\
(0.029) \\
{[0.091]}\end{array}$ & $\begin{array}{c}0.110 \\
(0.026)\end{array}$ & $\begin{array}{c}0.136 \\
(0.026) \\
{[0.098]}\end{array}$ & $\begin{array}{c}0.142 \\
(0.024)\end{array}$ & & \\
\hline Four-year & $\begin{array}{c}0.116 \\
(0.039) \\
{[0.561]}\end{array}$ & $\begin{array}{c}0.114 \\
(0.038)\end{array}$ & $\begin{array}{c}0.112 \\
(0.036) \\
{[0.56]}\end{array}$ & $\begin{array}{c}0.113 \\
(0.034)\end{array}$ & & \\
\hline Any & $\begin{array}{c}0.030 \\
(0.036) \\
{[0.71]}\end{array}$ & $\begin{array}{c}0.030 \\
(0.036)\end{array}$ & $\begin{array}{c}0.105 \\
(0.032) \\
{[0.682]}\end{array}$ & $\begin{array}{c}0.106 \\
(0.032)\end{array}$ & & \\
\hline $\begin{array}{l}\text { Covariates } \\
\text { Number of school-years } \\
\text { Number of students }\end{array}$ & \multicolumn{2}{|c|}{$\begin{array}{l}384 \\
883\end{array}$} & \multicolumn{2}{|c|}{$\begin{array}{c}441 \\
1,225\end{array}$} & & \\
\hline \multicolumn{7}{|c|}{ Panel D. Race/Ethnicity } \\
\hline & \multicolumn{2}{|c|}{ White or Asian } & \multicolumn{2}{|c|}{ Black } & \multicolumn{2}{|c|}{ Other } \\
\hline Highly competitive or above & $\begin{array}{c}0.145 \\
(0.024) \\
{[0.11]}\end{array}$ & $\begin{array}{c}0.148 \\
(0.021)\end{array}$ & $\begin{array}{l}0.100 \\
(0.076) \\
{[0.221]}\end{array}$ & $\begin{array}{c}0.085 \\
(0.064)\end{array}$ & $\begin{array}{c}0.051 \\
(0.072) \\
{[0.183]}\end{array}$ & $\begin{array}{c}0.060 \\
(0.076)\end{array}$ \\
\hline $\mathrm{UM}$ & $\begin{array}{c}0.142 \\
(0.023) \\
{[0.09]}\end{array}$ & $\begin{array}{c}0.144 \\
(0.020)\end{array}$ & $\begin{array}{c}0.016 \\
(0.067) \\
{[0.177]}\end{array}$ & $\begin{array}{c}0.023 \\
(0.062)\end{array}$ & $\begin{array}{c}0.051 \\
(0.071) \\
{[0.175]}\end{array}$ & $\begin{array}{c}0.058 \\
(0.074)\end{array}$ \\
\hline Four-year & $\begin{array}{l}0.105 \\
(0.031) \\
{[0.552]}\end{array}$ & $\begin{array}{c}0.110 \\
(0.030)\end{array}$ & $\begin{array}{l}-0.018 \\
(0.089) \\
{[0.695]}\end{array}$ & $\begin{array}{c}0.015 \\
(0.105)\end{array}$ & $\begin{array}{c}0.089 \\
(0.090) \\
{[0.497]}\end{array}$ & $\begin{array}{c}0.082 \\
(0.088)\end{array}$ \\
\hline Any & $\begin{array}{l}0.072 \\
(0.029) \\
{[0.687]}\end{array}$ & $\begin{array}{c}0.078 \\
(0.029)\end{array}$ & $\begin{array}{l}-0.014 \\
(0.080) \\
{[0.757]}\end{array}$ & $\begin{array}{c}0.007 \\
(0.092)\end{array}$ & $\begin{array}{c}0.047 \\
(0.086) \\
{[0.615]}\end{array}$ & $\begin{array}{c}0.060 \\
(0.086)\end{array}$ \\
\hline Covariates & $\mathrm{N}$ & $\mathrm{Y}$ & $\mathrm{N}$ & $\mathrm{Y}$ & $\mathrm{N}$ & $\mathrm{Y}$ \\
\hline $\begin{array}{l}\text { Number of school-years } \\
\text { Number of students }\end{array}$ & $\begin{array}{l}4 \\
1,\end{array}$ & $\begin{array}{l}6 \\
36\end{array}$ & & & & \\
\hline
\end{tabular}

Source: Michigan administrative data and National Student Clearinghouse data.

Notes: All analyses done at the school-year level. For Panels A and B, coefficients are from separate regressions of outcome on treatment status and strata dummies, estimated on the subgroup. For Panels C and D, coefficients are from separate regressions of school-subgroup-level outcome rate on treatment status and strata dummies. Covariates include all characteristics listed in Appendix Table II and are at the school-subgroup level. Robust standard errors reported in parentheses. Control mean for subgroup in brackets. Enrollment is measured at the first college attended in the two falls following expected high school graduation and is unconditional on any college enrollment. 
Appendix Table XVII

Estimated Spillover Effect of HAIL Scholarship on Non-HAIL Students First and Second HAIL cohorts

\begin{tabular}{|c|c|c|c|}
\hline & (1) & (2) & (3) \\
\hline \multicolumn{4}{|c|}{ Panel A. Application } \\
\hline Treatment Effect on non-HAIL students & $\begin{array}{l}-0.011 \\
(0.005)\end{array}$ & $\begin{array}{l}-0.000 \\
(0.002)\end{array}$ & $\begin{array}{c}0.001 \\
(0.002)\end{array}$ \\
\hline R-squared & 0.030 & 0.852 & 0.870 \\
\hline Strata dummies & $\mathrm{X}$ & $X$ & $\mathrm{X}$ \\
\hline 2015 application rate & & $\mathrm{X}$ & $\mathrm{X}$ \\
\hline 2009-2014 application rates & & & $\mathrm{X}$ \\
\hline \multicolumn{4}{|c|}{ Panel B. Admission } \\
\hline Treatment Effect on non-HAIL students & $\begin{array}{l}-0.005 \\
(0.003)\end{array}$ & $\begin{array}{l}-0.000 \\
(0.001)\end{array}$ & $\begin{array}{c}0.000 \\
(0.001)\end{array}$ \\
\hline R-squared & 0.024 & 0.782 & 0.828 \\
\hline Strata dummies & $\mathrm{X}$ & $\mathrm{X}$ & $\mathrm{X}$ \\
\hline 2015 admission rate & & $\mathrm{X}$ & $\mathrm{X}$ \\
\hline 2009-2014 admission rates & & & $\mathrm{X}$ \\
\hline \multicolumn{4}{|c|}{ Panel C. Enrollment } \\
\hline Treatment Effect on non-HAIL students & $\begin{array}{l}-0.004 \\
(0.002)\end{array}$ & $\begin{array}{c}-0.000 \\
(0.001)\end{array}$ & $\begin{array}{c}0.000 \\
(0.001)\end{array}$ \\
\hline R-squared & 0.022 & 0.725 & 0.770 \\
\hline Strata dummies & $\mathrm{X}$ & $\mathrm{X}$ & $\mathrm{X}$ \\
\hline 2015 enrollment rate & & $X$ & $\mathrm{X}$ \\
\hline 2009-2014 enrollment rates & & & $\mathrm{X}$ \\
\hline Number of school-years & & 1,025 & \\
\hline
\end{tabular}

Source: Michigan administrative data and University of Michigan Office of Enrollment Management data.

Notes: All analyses done at the school-year level. Coefficients are from regression of outcome rate for non-HAIL eligible students on treatment status and strata dummies, plus controls as indicated. Schools missing historical rates are assigned values of zero, and regressions include missingness indicators. Robust standard errors reported in parentheses. 
D Appendix Figures 
Appendix Figure I

First-time and Total Visits to HAIL Webpages, by HAIL Cohort

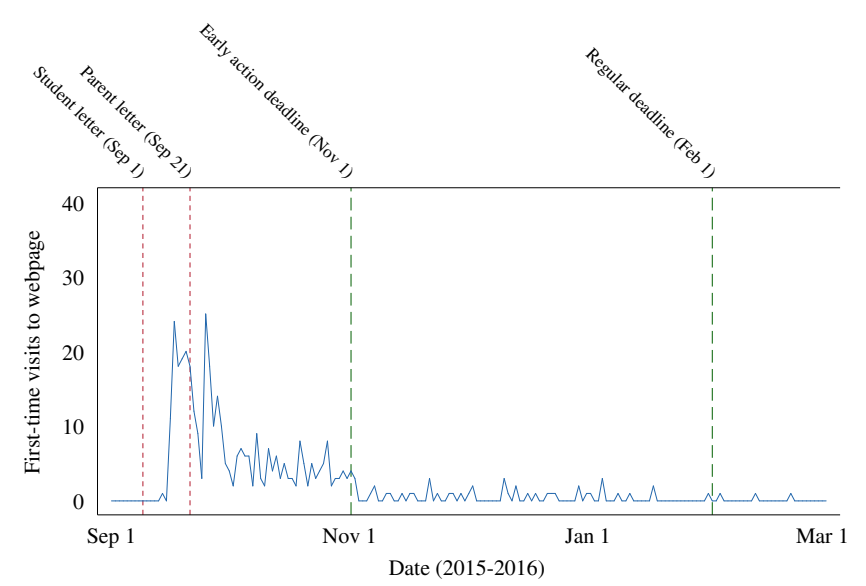

(a) First HAIL Cohort, First Time Page Views

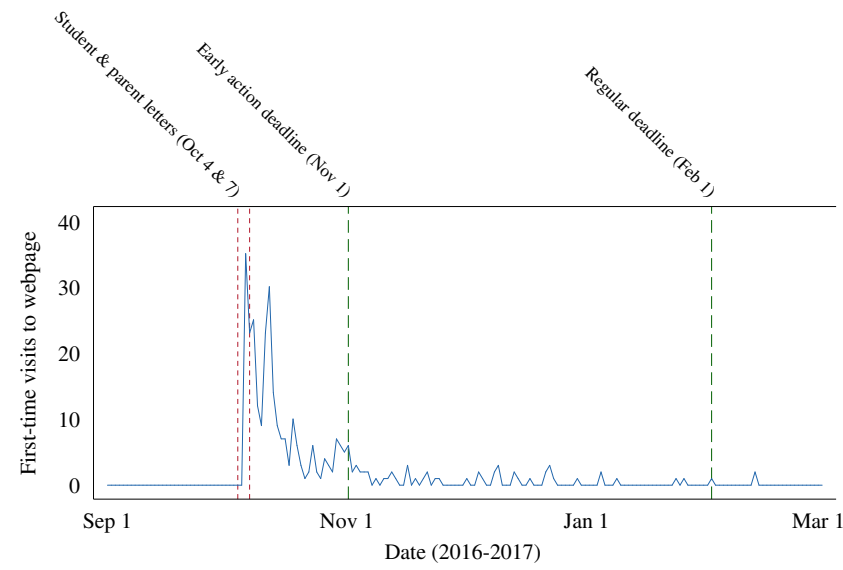

(c) Second HAIL Cohort, First Time Page Views

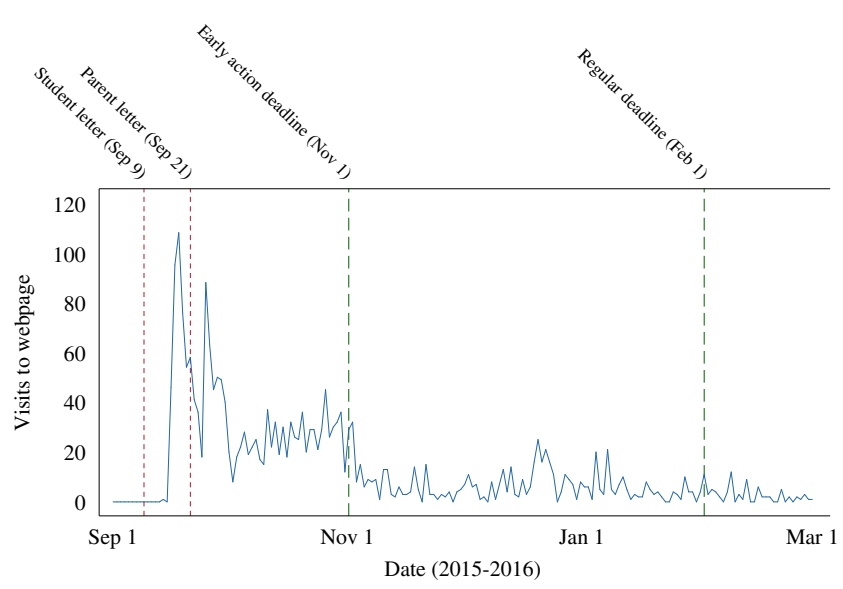

(b) First HAIL Cohort, Total Page Views

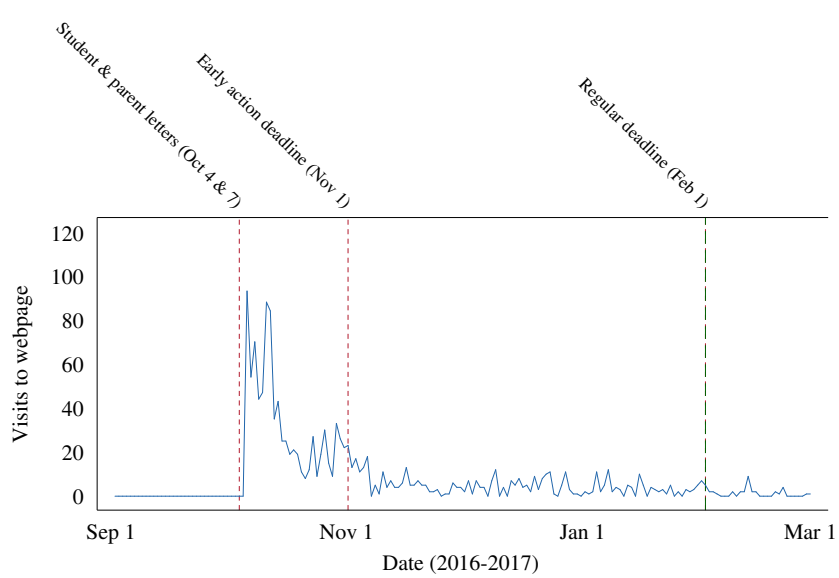

(d) Second HAIL Cohort, Total Page Views

Source: University of Michigan Office of Enrollment Management data.

Notes: For first time views, unit of analysis is a first-time visit to the personalized URL associated with a treated HAIL student, aggregated by date. For total views, unit of analysis is a visit to a personalized URL associated with a treated HAIL student, aggregated by date. 


\section{Appendix Figure II}

Estimated Effect of HAIL Scholarship on UM Application, Admission, and Enrollment First and Second HAIL Cohorts

(a) Applied

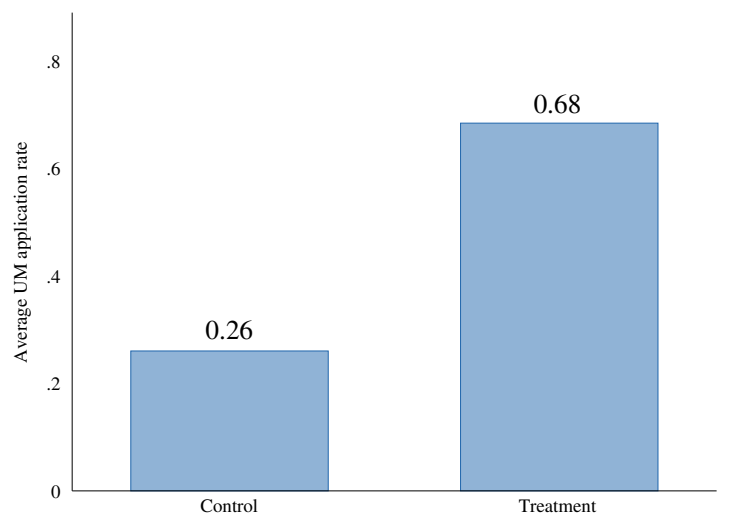

(b) Admitted

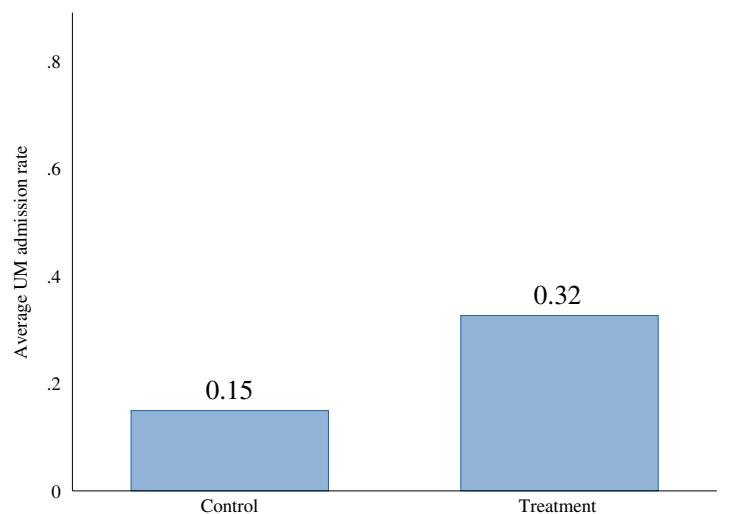

(c) Enrolled

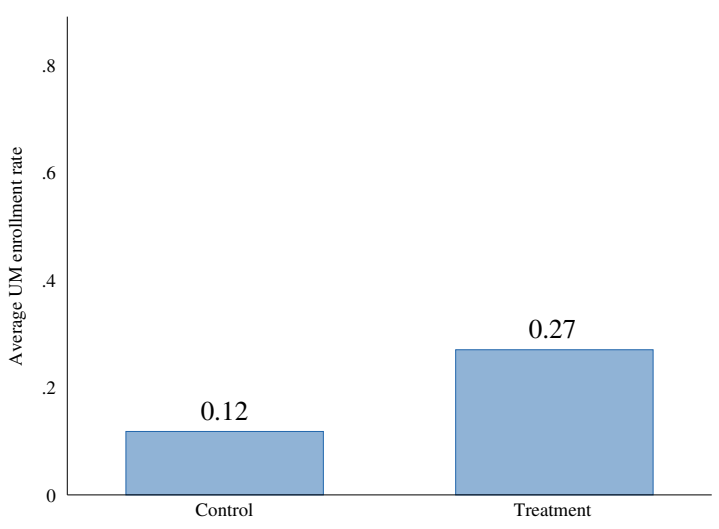

Source: Michigan administrative data and University of Michigan Office of Enrollment Management data.

Notes: All analyses done at the school-year level. Application, admission and enrollment measured in the summer and fall following expected high school graduation. Admission and enrollment are unconditional on application. 
Appendix Figure III

Randomization-Based Inference

(a) Highly competitive or above

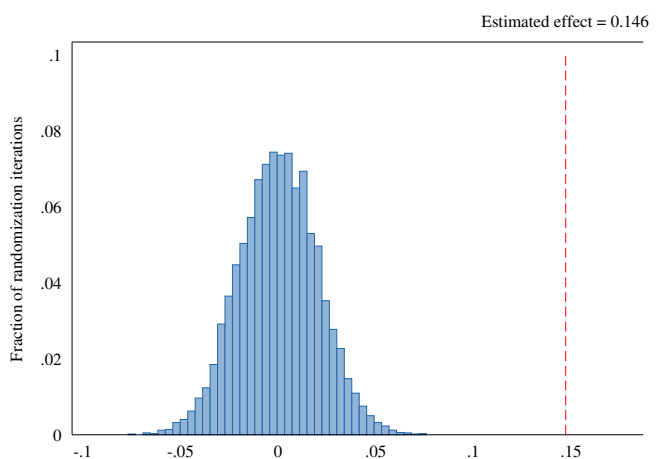

(d) Four-year

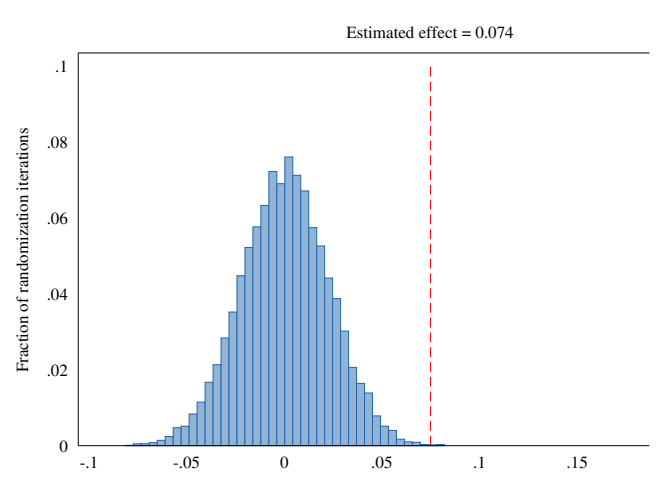

(b) UM

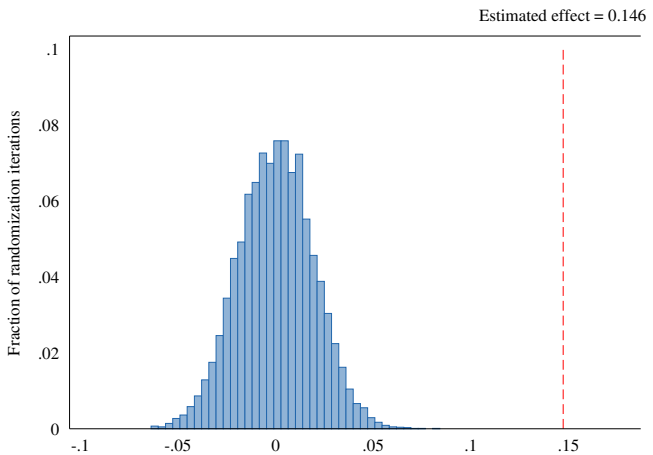

(e) Two-year

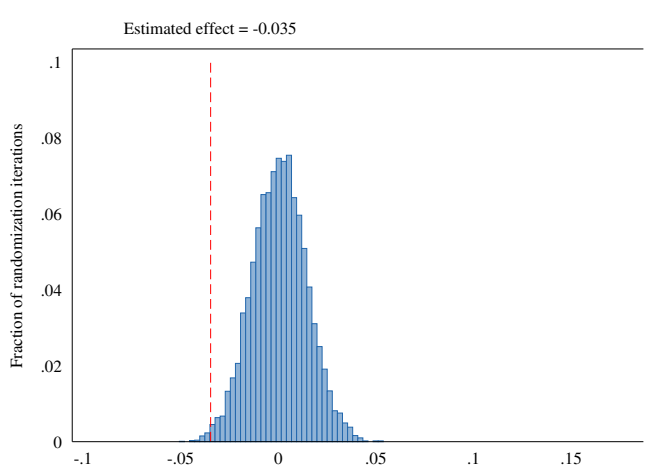

(c) Highly competitive or above other than UM

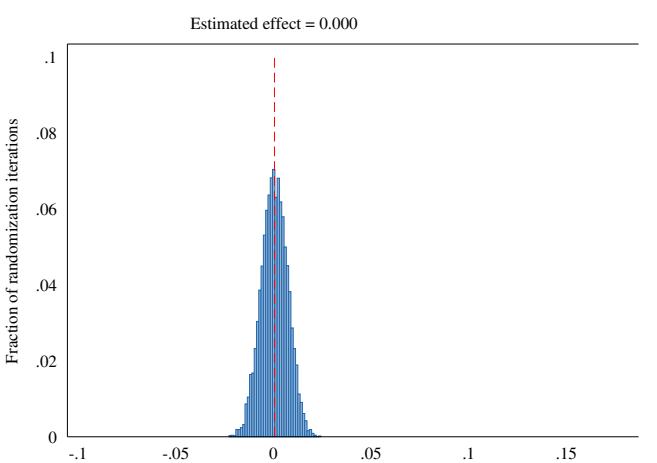

(f) Any

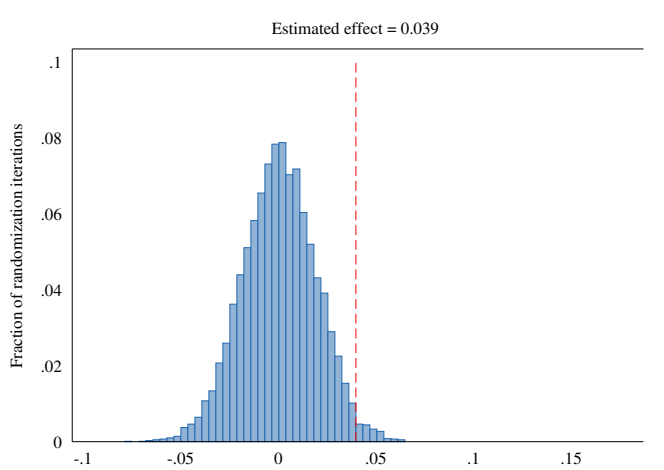

Notes: Each simulated treatment effect comes from first randomly assigning schools to treatment using the same randomization algorithm used for true assignment, then running a regression of the outcome on "treatment" status, including controls for strata. Exact p-value is calculated as the number of simulated effects greater in absolute value than the estimated effect. 


\section{Appendix Figure IV}

Estimated Effect of HAIL Scholarship on UM Application, Admission, and Enrollment by Region First and Second HAIL Cohorts

(a) Applied

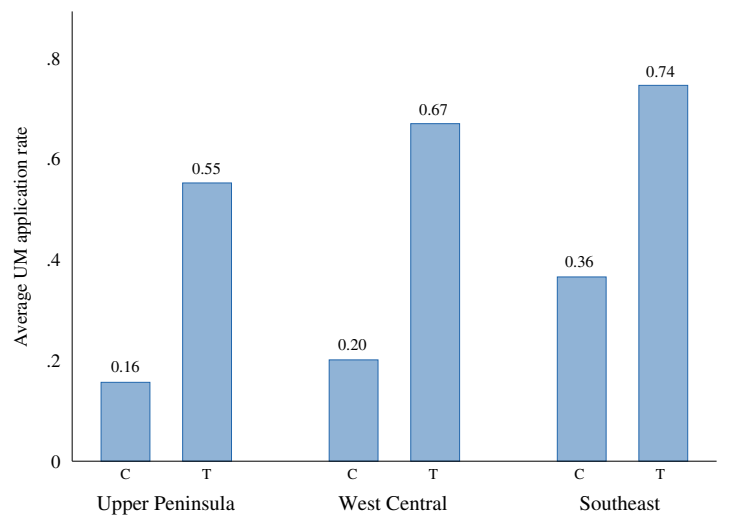

(b) Admitted

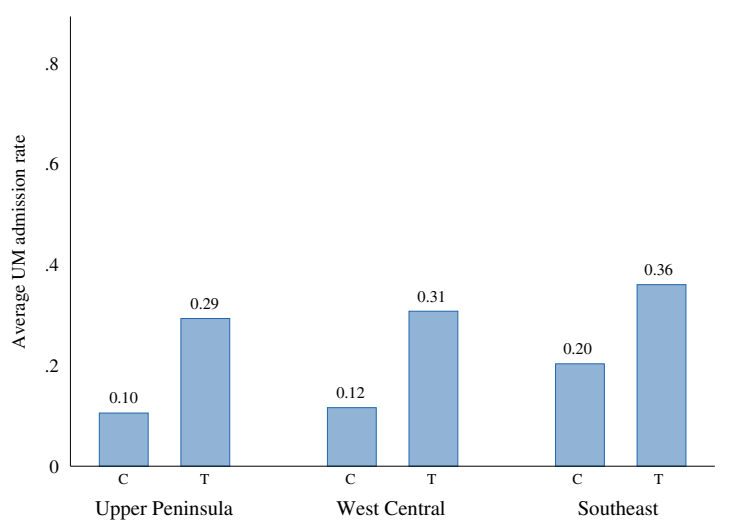

(c) Enrolled

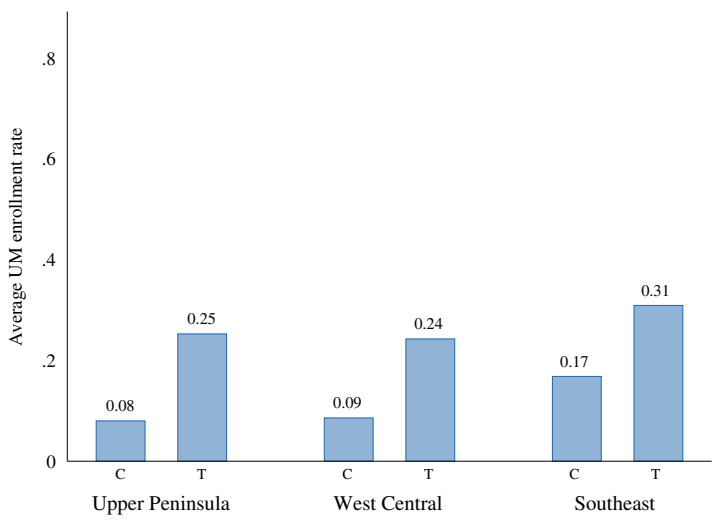

Source: Michigan administrative data and University of Michigan Office of Enrollment Management data.

Notes: All analyses done at the school-year level. Application, admission and enrollment measured in the summer and fall following expected high school graduation. Admission and enrollment are unconditional on application. Schools in the UP make up 14 percent of sample, while schools in West Central and Southeast Michigan represent 46 percent and 40 percent of the sample, respectively. 


\section{Appendix Figure V}

Estimated Effect of HAIL Scholarship on UM Application, Admission, and Enrollment by Urbanicity First and Second HAIL Cohorts

(a) Applied

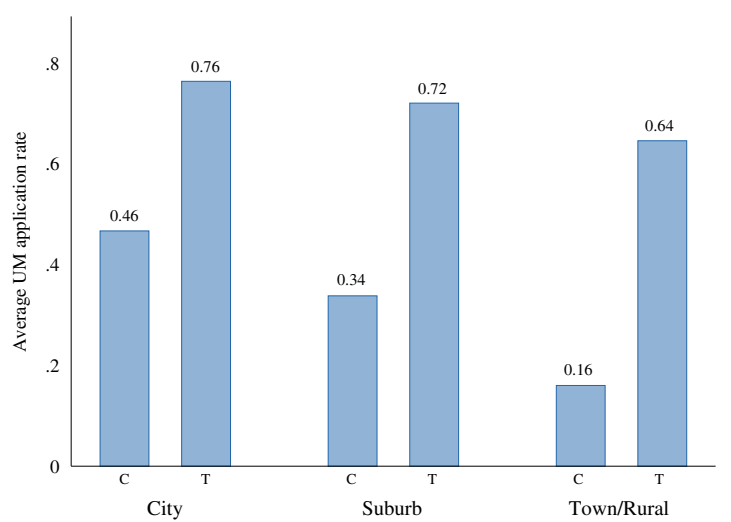

(b) Admitted

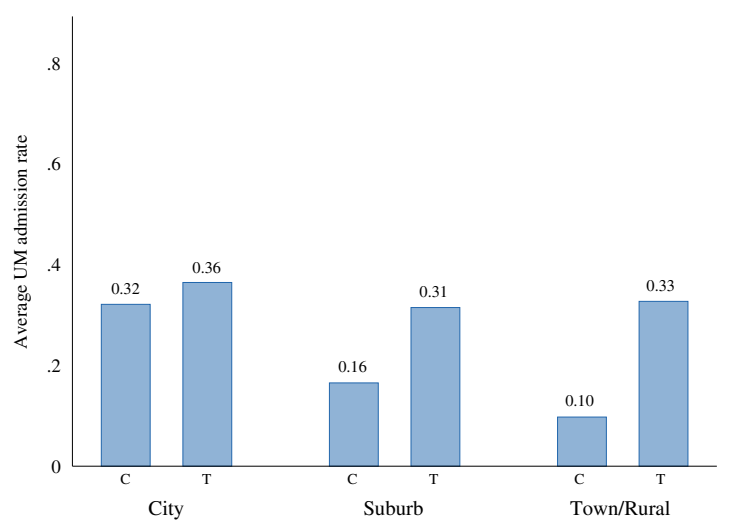

(c) Enrolled

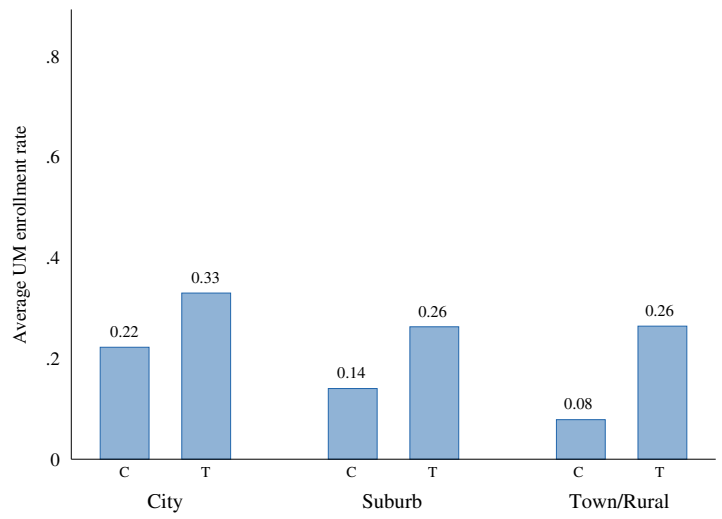

Source: Michigan administrative data and University of Michigan Office of Enrollment Management data.

Notes: All analyses done at the school-year level. Application, admission and enrollment measured in the summer and fall following expected high school graduation. Admission and enrollment are unconditional on application. Schools in suburban areas make up 35 percent of sample, while schools in cities and town or rural areas represent 12 percent and 54 percent of the sample, respectively. 


\section{Appendix Figure VI}

Estimated Effect of HAIL Scholarship on UM Application, Admission, and Enrollment by Gender First and Second HAIL Cohorts

(a) Applied

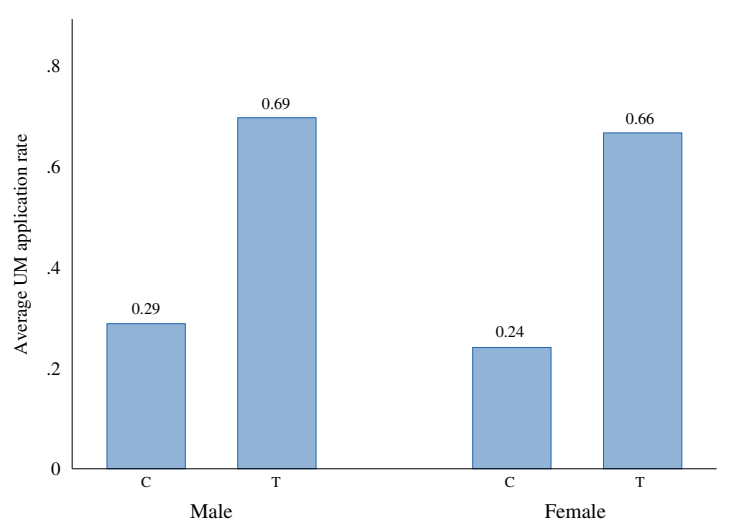

(b) Admitted

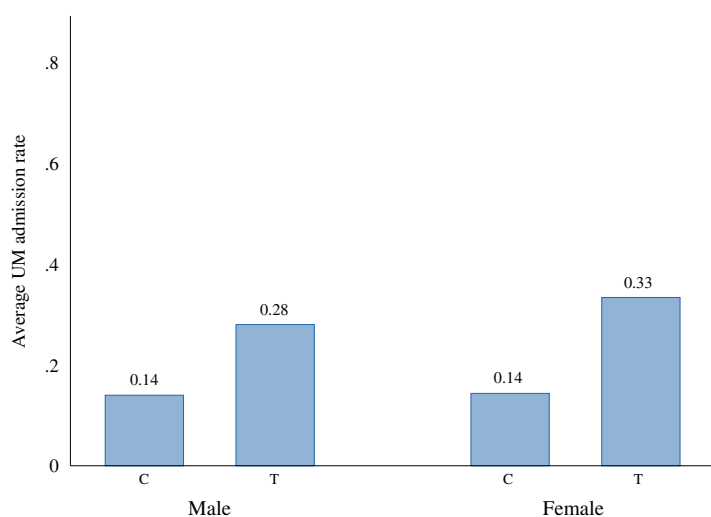

(c) Enrolled

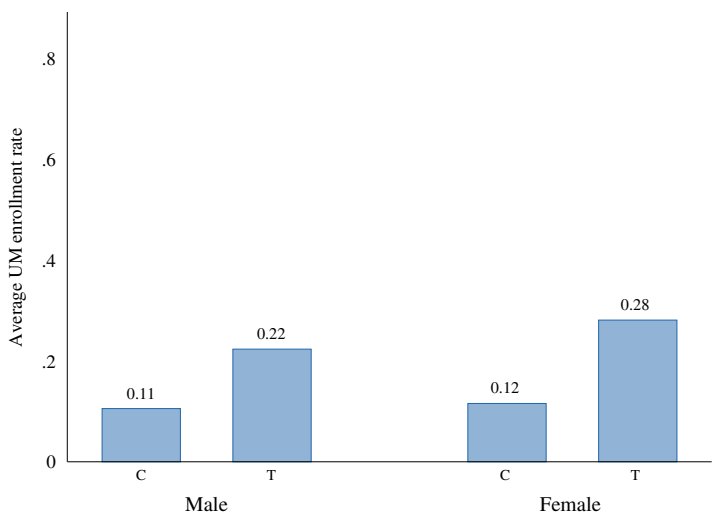

Source: Michigan administrative data and University of Michigan Office of Enrollment Management data.

Notes: Rates are gender-specific school-year averages. Application, admission and enrollment measured in the summer and fall following expected high school graduation. Admission and enrollment are unconditional on application. 83 percent of HAIL schools have at least one female HAIL student; 71 percent have at least one male. Female students represent 58 percent of the sample and male students represent 42 percent. 


\section{Appendix Figure VII}

Estimated Effect of HAIL Scholarship on UM Application, Admission, and Enrollment by Race/Ethnicity First and Second HAIL Cohorts

(a) Applied

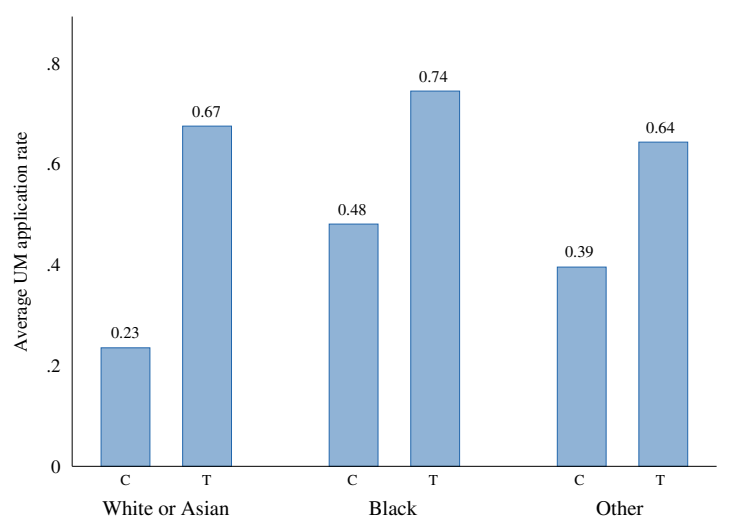

(b) Admitted

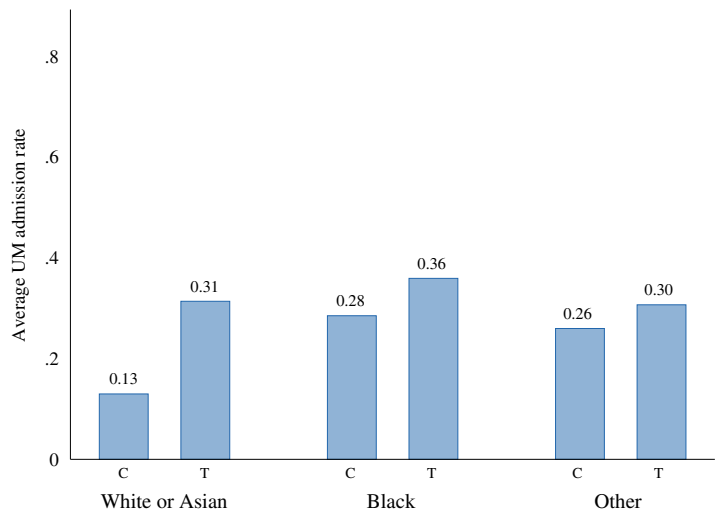

(c) Enrolled

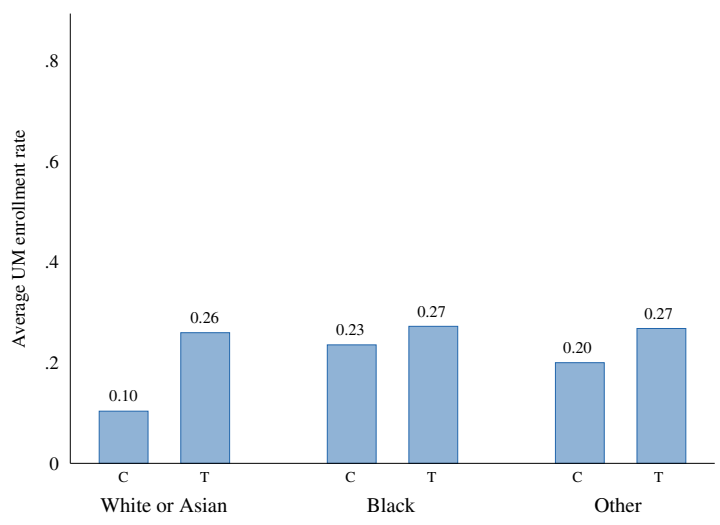

Source: Michigan administrative data and University of Michigan Office of Enrollment Management data.

Notes: Rates are race-specific school-year averages. Application, admission and enrollment measured in the summer and fall following expected high school graduation. Admission and enrollment are unconditional on application. 92 percent of HAIL schools have at least one white or Asian HAIL student; 20 percent have at least one black student and 19 percent have at least one student of another race or ethnicity. White and Asian students represent 85 percent of the sample; black students and students of another race or ethnicity represent 8 percent and 7 percent, respectively. 
Appendix Figure VIII

Estimated Effect of HAIL Scholarship on College Choice First and Second HAIL Cohorts

(a) Highly competitive or above

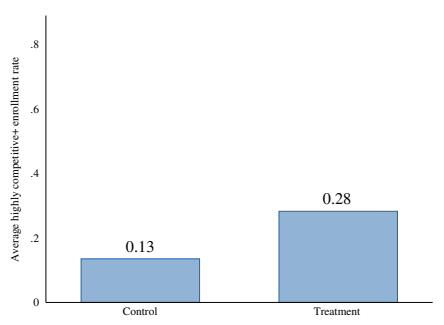

(d) Four-year

uै (b) UM

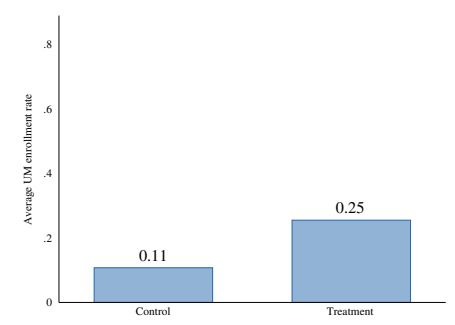

(e) Two-year

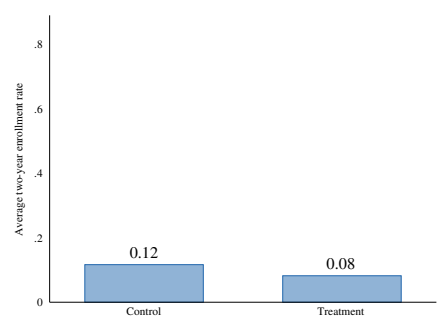

(h) Michigan Public

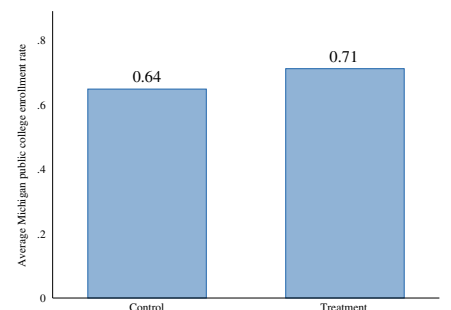

(c) Highly competitive or above other than UM

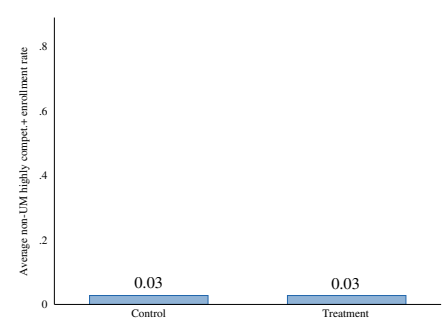

(f) Any

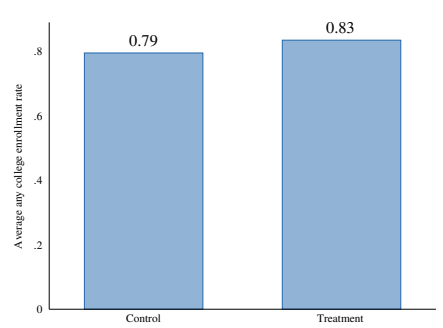

(i) Not in Michigan

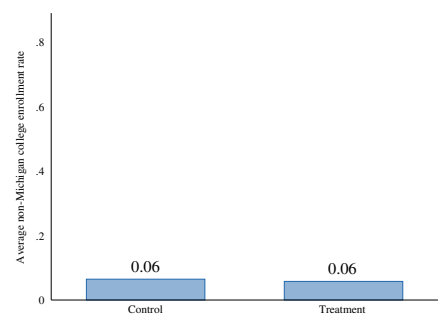

Source: Michigan administrative data and National Student Clearinghouse data.

Notes: All analyses done at the school-year-level. Enrollment measured at the first institution attended in the fall following expected high school graduation. Enrollment unconditional on any college enrollment. 